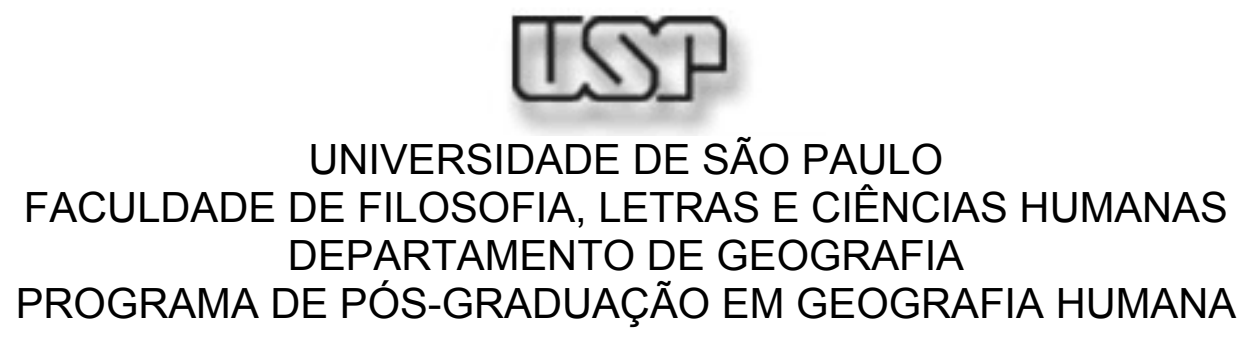

\title{
O PÃO NOSSO DE CADA DIA NOS DAI HOJE... Josué de Castro e a Inclusão da Fome nos Estudos Geográficos no Brasil
}

\author{
Antônio Alfredo Teles de Carvalho
}

São Paulo - SP 


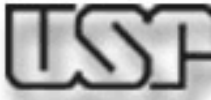

UNIVERSIDADE DE SÃO PAULO

FACULDADE DE FILOSOFIA, LETRAS E CIÊNCIAS HUMANAS DEPARTAMENTO DE GEOGRAFIA

PROGRAMA DE PÓS-GRADUAÇÃO EM GEOGRAFIA HUMANA

\section{O PÃO NOSSO DE CADA DIA NOS DAI HOJE... Josué de Castro e a Inclusão da Fome nos Estudos Geográficos no Brasil}

\section{Antônio Alfredo Teles de Carvalho}

Tese apresentada ao Programa de Pós-Graduação em Geografia Humana da Faculdade de Filosofia, Letras e Ciências Humanas da Universidade de São Paulo, como requisito parcial à obtenção do título de Doutor em Geografia Humana.

Orientadora: Professora Doutora Iraci Gomes de Vasconcelos Palheta.

São Paulo - SP

2007 
BANCA EXAMINADORA 
Deus, que me concedeu a graça de concluir mais uma etapa;

Dona Christina e Seu Andrade; João Paulo e Vanessa; Kiko, Sílvia e Jasmim; Júnior, Adriana e Isabella, por tudo que representaram no processo de sua feitura, ao longo de quatro anos - atenção, no carinho e especialmente, no amor que me dispensaram, tornando a minha vida em São Paulo mais prazerosa e feliz;

Minha querida irmã Maria de Fátima, meu irmão José Vrbano e ao meu querido sobrinho Francisco Antonio, fontes inesgotáveis de amor, sempre presentes na minha vida.

É dedicado este trabalho 


\section{AGRADECIMENTOS}

Primeiramente e sempre, a Professora Doutora Iraci Gomes de Vasconcelos Palheta, minha orientadora, por tudo que representou nessa caminhada, a que fui levado através da Professora Doutora Ana Fani Alessandri Carlos, a que serei sempre grato pela oportunidade que me proporcionou.

A Professora Doutora Maria Laura Silveira e ao Professor Doutor Armen Mamigonian, pelas contribuições no exame de qualificação, pela boa vontade em contribuir, sugerindo, fornecendo informações; mas sobretudo, pela amizade.

Professor Doutor André Roberto Martin, Coordenador do Programa de PósGraduação em Geografia Humana, pelo socorro na reta final.

A Professora Doutora Edvania Torres, pelo acompanhamento no início desse processo.

Aninha, Cida, Jurema e Rosangela, funcionarias da Secretaria do Programa de Pós-Graduação em Geografia.

Flô e Aninha, técnicas do Labur e do Laboplam, respectivamente, sempre alegres e prestativas.

Danilo Valochko, Rafael de Pádua e Sávio Augusto, sem os quais tudo seria mais difícil. Amigos de todas as horas, facilitaram ao máximo a minha vida em São Paulo.

Bruno Maia Halley, grande amigo, presente em quase todos os momentos, especialmente quando se fez necessária a sua presença.

Professor Washington Viana Alves, pela disposição em ajudar, assumindo parte das minhas atribuições profissionais.

Gabrielly Oliveira, Kaciano Lira e Sidinei dos Santos, alunos queridos, pela força e disposição em contribuir todas as vezes que foram solicitados.

Dhiego Medeiros, também aluno, um agradecimento especial pela inestimável contribuição na reta final do trabalho.

Evanise Carvalho, coordenadora da Biblioteca Setorial do Centro de Filosofia e Ciências Humanas da Universidade Federal de Pernambuco, com toda a sua equipe, pela ajuda indispensável.

Anna Maria de Castro, seu esposo Ernesto e seu filho Cláudio; Josué Fernando, sua esposa Edda e Josué Fernando Filho (filhos, genro, nora e netos de Josué de Castro), que mais uma vez amavelmente me abriram as suas portas, me cederam documentos e informações. 


\section{RESUMO}

CARVALHO, Antônio Alfredo Teles de. O PÃO NOSSO DE CADA DIA NOS DAI HOJE... Josué de Castro e a Inclusão da Fome nos Estudos Geográficos no Brasil

Contemplando um recorte temporal de dezessete anos (1937/1954), o trabalho apresentado insere-se na área de história do pensamento geográfico. Está centrado na tese que o médico e geógrafo pernambucano Josué de Castro foi introdutor da 'geografia da fome' na história do pensamento geográfico no Brasil no interstício assinalado. Utilizando e concebendo o método geográfico como o único que permitia analisar a fome em toda a sua complexidade, sem dissociá-la das texturas do processo social subjacente a sua criação, o autor elucidou e denunciou esse espectro que assolava aproximadamente dois terços da humanidade do seu tempo. Nesse contexto, a sua obra seminal Geografia da Fome, publicada e 1946, constituiu-se num marco; primeiro, por introduzir um tema inédito dentro da Geografia no país, significativamente influenciada pela Escola Francesa e estudando os gêneros de vida, naturalmente voltava-se a análise da alimentação, sem entrementes fazer referência a fome; segundo, por provar que a fome consistia numa expressão biológica dos malefícios sociais especialmente nas periferias do capitalismo; e terceiro, em face a essa leitura, pelas possibilidades acenadas à análise do social na Geografia. Destarte, assume relevância e apresenta-se como uma expressiva referência da Geografia no Brasil e um imperativo no estudo da fome como tema passível de investigação pela mesma. Palavras-chaves: Josué de Castro, geografia, fome, Brasil. 


\begin{abstract}
Contemplating a period of seventeen years (1937/1954), the work presented inserts itself in the area of history of the geographical thought. It is centered in the theory that the doctor and geographer from Pernambuco Josué de Castro was introdutor of the 'geography of the hunger' in the history of the geographical thought in Brazil in the designated time. Using and conceiving the geographical approach as the only one that allowed to analyze the hunger in all its complexity, without dissociating it from the textures of the underlying social process of its creation, the author explained and denounced that spectrum that devastated approximately two thirds of the humanity of his time. In that context, his seminal work Geografia da Fome, published in 1946, was very important; first, by introducing an unpublished subject inside the country's Geography that was significantly influenced by the French School that studied the ways of life, naturally concentrating itself in the analysis of the food, without reference to the hunger; second, by proving that the hunger consisted of a biological expression of the social problems specially in the edges of the capitalism; and third, according to that reading, by openning to the Geography the possibility to analyse social matters. Therefore, it shows relevance and presents-itself as an expressive reference of the Geography in Brazil and imperative to the study of the hunger as a subject possible to be researched by it. Keywords: Josué de Castro, geography, hunger, Brazil.
\end{abstract}


A esta geografia humana, renovada em seu espirito, ou, talvez mais exatamente, recolocada no caminho que the abriram nossos mestres, presta Josué de Castro uma excelente contribuiçãa.

Max Sorre 


\section{DEDICATORIA}

AGRADECIMENTOS

RESUMO

ABSTRACT

LISTA DE FOTOGRAFIAS

Foto 01 - Josué de Castro (Conclusão do Curso de Medicina) aos 24 anos.

Foto 02 - Solenidade de Posse de Josué de Castro na Cátedra de Geografia Humana da Faculdade Nacional de Filosofia da Universidade do Brasil em 14 de julho de 1948.

\section{LISTA DE GRÁFICOS}

Gráfico 01 - Produção Acadêmica em História do Pensamento Geográfico no Brasil - 2000/2006. 26

\section{LISTA DE QUADROS}

Quadro 01 - Produção Acadêmica em História do Pensamento Geográfico no Brasil - 1980/1989

Quadro 02 - Produção Acadêmica em História do Pensamento Geográfico no Brasil - 1990/1999

Quadro 03 - Produção Acadêmica em História do Pensamento Geográfico no

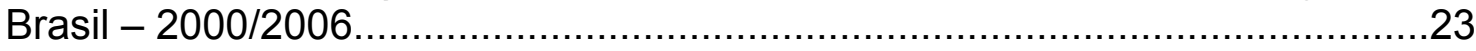

Quadro 04 - Teses de Doutoramento Orientadas por Pierre Monbeig............37

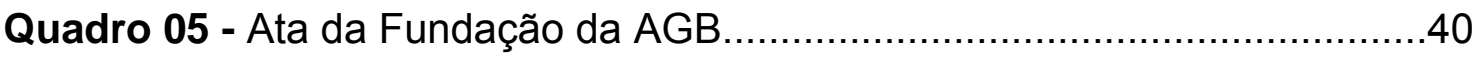

Quadro 06 - Assembléias Gerais da AGB (1945 - 1969)............................42

Quadro 07 - Fragmentos do Discurso Pronunciado por Josué de Castro na Solenidade de Inauguração da Faculdade de Filosofia e Ciências Sociais do Recife.

Quadro 08 - A Alimentação Brasileira à Luz da Geografia Humana por Afrânio Peixoto 64

Quadro 09 - Princípios Geográficos. .67 
Quadro 10 - Zoneamento do Brasil em Função dos Tipos Regionais de

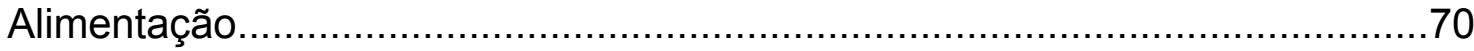

Quadro 11 - Concurso para a Cátedra de Geografia Humana da Faculdade Nacional de Filosofia da Universidade do Brasil...

Quadro 12 - Posse de Josué de Castro na Cátedra de Geografia Humana da Faculdade Nacional de Filosofia da Universidade do Brasil - I

Quadro 13 - Posse de Josué de Castro na Cátedra de Geografia Humana da Faculdade Nacional de Filosofia da Universidade do Brasil - II.

Quadro 14 - Posse de Josué de Castro na Cátedra de Geografia Humana da Faculdade Nacional de Filosofia da Universidade do Brasil - III

Quadro 15 - Produção Acadêmica Sobre Josué de Castro

\section{LISTA DE MAPAS}

Mapa 01 - Zonas Alimentares do Brasil..............................................69

Mapa 02 - Áreas Alimentares no Brasil....................................................94

Mapa 03 - Principais Carências Existentes nas Diferentes Áreas Alimentares do Brasil.

CONSIDERAÇÕES INICIAIS.

I PARTE - COADUNANDO AS PARTES E ESBOÇANDO UM

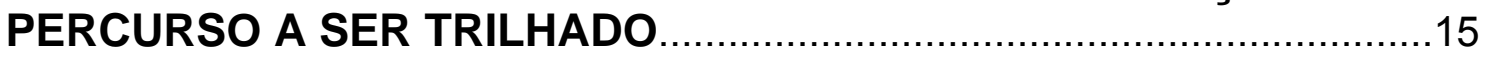

I Capítulo - Insurgência dos Estudos sobre a História do Pensamento Geográfico no Brasil nos Derradeiros Decênios do Século XX.

II Capítulo - Delimitando e Discutindo o Objeto de Estudo à Luz da História do Pensamento Geográfico.

II PARTE - FOME: DESCONTRUINDO UM CONCEITO E DECIFRANDO AS ESPECIFICIDADES SUBJACENTES .....................57

III Capítulo - Desvelando um Tema nas Entrelinhas da História. .58

IV Capítulo - Revisitando os Pressupostos da Fome como uma Categoria de Análise na Geografia.

III PARTE - JOSUÉ DE CASTRO E A INCLUSÃO DA FOME NOS
ESTUDOS GEOGRÁFICOS NO BRASIL

V Capítulo - Josué de Castro e a Geografia: Recuperando um Percurso........72

VI Capítulo - Geografia da Fome - Consubstanciação e Matriz dos Estudos sobre a Fome no Brasil e na História do Pensamento Geográfico Brasileiro....91 
CONSIDERAÇÕES FINAIS (Desdobramentos da Contribuição de Josué de Castro) .96

BIBLIOGRAFIA

ANEXOS 


\section{CONSIDERAÇÕES INICIAIS}

Pensar o presente e projetar o futuro sugere revisitar o passado. E em tempos caracterizados pela aceleração, mais que uma possibilidade, constitui uma necessidade. Partindo dessa perspectiva, pensar a Geografia hoje, ou refletir a propósito dos seus possíveis desdobramentos passa necessariamente pelo resgate e apreensão da sua história particular, articulada com a história do tempo em que se processara. Como bem afirma a geógrafa espanhola Josefina Gómez Mendonza, "toda teoria científica está influenciada por códigos culturais da sociedade que a produz, e nesse sentido, produção e reprodução científicas tem a ver com produção e reprodução sociais" (MENDONZA, 1986, p. 7).

Trilhando essa perspectiva a pesquisa apresentada revela-se como uma possibilidade de refletir e analisar a geografia da fome à luz da história do pensamento geográfico no Brasil entre 1937 e 1954, a partir da contribuição de Josué de Castro.

Para um melhor entendimento desse processo, faz-se mister, aqui discorrer a propósito das orientações metodológicas utilizadas para tal fim. Como ponto de partida, buscou-se maior aprofundamento da noção de pensamento geográfico, partindo de uma definição. Nesse sentido, a desenvolvida por Moraes mostrou-se a mais adequada aos objetivos propostos pelo trabalho. Para este autor, entende-se por pensamento geográfico um

conjunto de discursos a respeito do espaço que substantivam as concepções que uma dada sociedade, num momento determinado, possui acerca do seu meio (desde o local ao planetário) e das relações com ele estabelecido. Tratase de um acervo histórico e socialmente produzido, uma fatia de substância da formação cultural de um povo (MORAES, 1991, p. 32)

E, que por assim ser, "abrangeria os vários significados históricos do rótulo Geografia, suas fontes, bem como as reflexões procedentes de outras disciplinas que numa ótica central ou marginal tocassem nos temas do conteúdo atualmente assumido" (MORAES, 1991, p. 32). 
Esta perspectiva mostrou-se fundamental ao desenvolvimento da pesquisa, especialmente por acenar à interlocução com outras disciplinas, a exemplo da História, Sociologia, Economia e da Medicina, dentre outras. Essencial para analisar um autor plural como Josué de Castro no seu contexto, que apresenta-se como um dos mais efervescentes da recente história brasileira.

O recorte temporal analisado corresponde a um período de dezessete anos e foi analisado a partir da periodização da evolução da pesquisa geográfica no Brasil, organizada por Monteiro (1980), cujo esquema é o seguinte:

$\checkmark$ 1934-1948 - Implantação da Geografia Científica

$\checkmark$ 1948-1956 - Cruzada Agebeana de Difusão Nacional

$\checkmark$ 1956-1968 - A Caminho da Afirmação (Primeira Época)

$\checkmark$ 1968-1977 - A Caminho da Afirmação (Segunda Época)

Tomou-se os dois primeiros períodos (sem no entanto desconsiderar o precedente e o subseqüente) para uma análise contextual, onde Josué de Castro emerge para uma centralidade indiscutível à compreensão do universo intelectual e geográfico brasileiro dos meados do século passado. As premissas por ele esboçadas foram assim adotadas. Contudo sem absorvê-las de forma mais rigorosa, mas como uma proposta de caminho a ser percorrido na leitura e análise da história do pensamento geográfico no Brasil, considerando-se as suas especificidades, bem como as especificidades identificadas na construção da formação intelectual e na obra de Josué de Castro.

Para Monteiro (2002, p. 4), uma abordagem histórica do desenvolvimento da Geografia no Brasil deve contemplar quatro aspectos que considera essenciais a caracterização da Geografia feita no Brasil ao longo do século XX:

$\checkmark$ Assentar as bases da avaliação através dos vetores básicos da produção geográfica, a saber: a Universidade como centro de produção; a Fundação IBGE como aplicação oficial e a Associação dos Geógrafos 
Brasileiros como refletor das tendências e conflitos na comunidade de geógrafos do Brasil;

$\checkmark$ Observar, ao longo do século, os eventos básicos no desenvolvimento cronológico linear, de modo a possibilitar uma articulação sincrônica capaz de sugerir definição de momentos ou fases característicos nesta evolução;

$\checkmark$ Integrar esta possível periodização em face de uma projeção intrageográfica na produção brasileira, com a consideração dos insumos advindos dos eventos mundiais e as respectivas repercussões na Geografia, nos centros hegemônicos de saber, do poder econômico e político mundial. Em suma, avaliar as mutações no mundo e em suas geografias ao mesmo tempo em que se avaliam as ligações emanadas dos centros polarizadores e recebidas nas periferias nesta perspectiva global caracterizada, sobretudo, por grandes diferenças nos graus de desenvolvimento;

$\checkmark$ Finalmente procurar, nesta periodização caracterizadora, articular as relações entre as direções e tendências da Geografia, com os grandes projetos políticos vigentes no país ao longo do século. Com auxilio de alguns quadros demonstrativos dessas correlações e sintetizadores dessas características em sua periodização, procurar-se-á diminuir a extensão do texto.

Ancorado nessas concepções revisitou-se a história do pensamento geográfico no Brasil à luz dos processos em curso (no país e no mundo) nos meados do século $X X$, focalizando Josué de Castro como intelectual e sujeito pensante da Geografia.

O trabalho está fundamentado e organizado a partir das reflexões e das conclusões derivadas das correspondências, documentos, livros, artigos e manuscritos do próprio Josué de Castro, bem como de referências bibliográficas existentes sobre ele e a geografia da fome. Estrutura-se em três partes e seis capítulos. 
Os dois capítulos que compõem a primeira parte consiste num resgate das investigações sobre a história do pensamento geográfico no Brasil, seguido da apresentação e contextualização do objeto de estudo.

Na segunda parte (capítulos III e IV) é feita uma reconstituição histórica da fome e discutida a sua análise na perspectiva geográfica, onde é evidenciada a contribuição de Josué de Castro.

A terceira parte, constituída pelos capitulo $\mathrm{V}$ e $\mathrm{VI}$ trata da incursão de Josué de Castro pela Geografia até se transformar na principal matriz dos estudos sobre a fome no Brasil e na história do pensamento geográfico brasileiro.

Seguindo esse percurso foi possível perceber que a obra de Josué de Castro sistematiza um discurso sobre a fome no Brasil a partir de 1930 e estende-se pelos três decênios subseqüentes. E, como já havia observado Magalhães (1997, p. 10), o seu pensamento tomou uma dimensão que vai além das fronteiras nacionais, representando não apenas uma visão da fome, como também uma visão da saúde e da sociedade ao longo de um certo tempo. 


\section{PARTE}

COADUNANDO AS PARTES E ESBOÇANDO UM PERCURSO A SER TRILHADO 


\section{Capítulo - Insurgência dos Estudos sobre a História do Pensamento Geográfico no Brasil nos Derradeiros Decênios do Século XX.}

Os vinte derradeiros anos do século passado constituem dois decênios marcantes para os estudos sobre a história do pensamento geográfico no Brasil, assinalando a sua emergência e desenvolvimento dentro do meio acadêmico. Perceba-se, que até então, os estudos mais representativos na área consistiam em empreitadas solitárias de dois ícones da Geografia brasileira - A Geografia no Brasil, de José Veríssimo da Costa Pereira, artigo integrante da coletânea As Ciências no Brasil, organizada por Fernando de Azevedo e publicada pela Editora Melhoramentos de São Paulo em 1955 ${ }^{1}$; e A Geografia no Brasil (1934-1977): Avaliação e Tendências², de Carlos Augusto de Figueiredo Monteiro, publicado pelo Instituto de Geociências da Universidade de São Paulo, dentro da série Teses e Monografia, em $1980^{3}$.

Portanto, tardiamente insurge aqui, uma tendência iniciada na Europa pelo menos vinte ou trinta anos antes. Na análise de Mamigonian (2003, p. 7), "um século após a consolidação da Geografia, fundada na Alemanha por Alexander von Humboldt e Karl Ritter, e meio século após a consolidação da geografia francesa, fundada por Paul Vidal de La Blache, historicamente a segunda grande escola geográfica do mundo". Entretanto, observa Silva (1996, p. 06) que a análise de trabalhos destinados à reflexão em torno da natureza do pensamento geográfico brasileiro, sobretudo numa perspectiva histórica,

\footnotetext{
${ }^{1}$ Reeditado em 1994 pela Editora da Universidade Federal do Rio de Janeiro.

2 Revisto, ampliado e reeditado em 2002 dentro da Série O Borrador, $n$. 04, da AGB - São Paulo, com o título A Geografia no Brasil ao Longo do Século XX: Um Panorama.

3 Faz-se necessário, aqui, acrescentar a esses dois trabalhos pioneiros, três ensaios publicados entre 1977 e 1988 que de certa forma constituem um imperativo para quem estuda o pensamento geográfico no Brasil a partir da sua institucionalização em 1934. Refiro-me a $O$ Pensamento Geográfico e a Realidade Brasileira, de Manuel Correia de Andrade, publicado no Boletim Paulista de Geografia. n 54, São Paulo: AGB, 1977. p. 5-28; A Influência Estrangeira no Desenvolvimento da Geografia no Brasil, de Nilo Bernardes, publicado na Revista Brasileira de Geografia. n 3, Rio de Janeiro: IBGE, 1982. p. 519-527; e Industrialização no Brasil, Conhecimento e Atuação da Geografia, de Pedro Pinchas Geiger, igualmente publicado na Revista Brasileira de Geografia. Número Especial. Rio de Janeiro: IBGE, 1988. p. 59-84.
} 
ainda revela uma lacuna muito grande e ao mesmo tempo sintomática. Trilhando nessa perspectiva conclui que

A tradição desta disciplina constitui-se de uma orientação profundamente pragmática e destituída de uma real e consciente sedimentação teórica. Situação que vem caracterizando a Geografia, ao longo de sua trajetória, como um perfeito exemplo de um saber que não reflete sobre si mesmo e, principalmente, suas relações com seu objeto de análise (SILVA, 1996, p. 06).

Não obstante a observação do aludido autor, a partir de 1980 estudos dessa natureza passam a despertar maior interesse dos geógrafos brasileiros e, assim, vem à luz significativos trabalhos emanados de investigações desenvolvidas especialmente nos Programas de Pós-Graduação em Geografia - que passaram a se constituir nos centros por excelência dessa produção, inicialmente nas universidades paulistas (sobretudo Universidade de São Paulo e Universidade Estadual Paulista Julio Mesquita Filho - campus de Rio Claro), para posteriormente expandir-se para outras partes do país.

Nesse sentido, os levantamentos realizados nos Programas de PósGraduação em Geografia da Universidade de São Paulo (USP), Universidade Estadual Paulista Julio de Mesquita Filho (UNESP - campus de Rio Claro e de Presidente Prudente), Universidade Federal do Rio de Janeiro (UFRJ), Universidade Federal Fluminense (UFF), Universidade do Estado do Rio de Janeiro (UERJ), Universidade Federal de Pernambuco (UFPE), Universidade Federal de Santa Catarina (UFSC), afora os Programas de Pós-Graduação em Educação da Pontifícia Universidade Católica de São Paulo (PUC-SP), UERJ, UFSC e, ainda, o Programa de Pós-Graduação em Integração da América Latina (PROLAM) da USP, Ciência da Informação da UFRJ e Memória Social da Universidade Federal do Estado do Rio de Janeiro (UNIRIO), são bastante elucidativos.

Afora o crescimento quantitativo dessa produção, conforme pode ser constatado nos quadros 01, 02 e 03, também é perceptível a sua diversidade temática. Contudo, observam-se como temas predominantes (1) autores; (2) instituições do saber geográfico e (3) evolução do pensamento geográfico. 
Conforme mostra o quadro 01 , os primeiros estudos em história do pensamento geográfico no Brasil nos primórdios dos anos 80 versam sobre autores. Nessa perspectiva, expressivos nomes da Geografia universal e brasileira, a exemplo de Max Sorre, Humboldt, Ritter e Ratzel, Aroldo de Azevedo e Delgado de Carvalho constituíram objetos de estudo dos geógrafos brasileiros.

Quadro 01 - Produção Acadêmica em História do Pensamento Geográfico no Brasil - 1980/1989.

\begin{tabular}{|l|l|l|l|l|}
\hline \multicolumn{1}{|c|}{ AUTOR } & \multicolumn{1}{|c|}{ TRABALHO } & TIPO & IES & ANO \\
\hline $\begin{array}{l}\text { Januário } \\
\text { Megale }\end{array}$ Francisco & $\begin{array}{l}\text { Geografia e Sociologia: Introdução } \\
\text { ao Estudo de Max Sorre. }\end{array}$ & Tese & USP & 1980 \\
\hline Antonio Carlos R. Moraes & $\begin{array}{l}\text { Contribuição para uma História } \\
\text { Crítica do Pensamento Geográfico: } \\
\text { Alexander Von Humboldt, Karl } \\
\text { Ritter, Friedrich Ratzel }\end{array}$ & Dissert. & USP & 1983 \\
\hline Wilson dos Santos & $\begin{array}{l}\text { A Obra de Aroldo de Azevedo: uma } \\
\text { avaliação }\end{array}$ & Dissert. & UNESP \\
(RC) & 1984 \\
\hline $\begin{array}{l}\text { Raquel Maria Fontes do } \\
\text { Amaral Pereira }\end{array}$ & $\begin{array}{l}\text { Da Geografia que se Ensina à } \\
\text { Gênese da Geografia Moderna }\end{array}$ & $\begin{array}{c}\text { Dissert. } \\
\text { (Educação) }\end{array}$ & UFSC & 1988 \\
\hline Cláudio Benito O. Ferraz & $\begin{array}{l}\text { Delgado de Carvalho no Contexto } \\
\text { Da Geografia Brasileira - 1913 a } \\
\text { 1942 }\end{array}$ & Dissert. & USP & 1989 \\
\hline
\end{tabular}

Fonte: Pesquisa Direta

Organização: Antônio Alfredo Teles de Carvalho - 2005/2007

Nas décadas subseqüentes essa tendência mostrar-se-ia ainda mais intensa com novos estudos contemplando além dos autores clássicos já mencionados, outros como Vida de La Blache, Léo Waibel, Pierre Monbeig, Josué de Castro e Manuel Correia de Andrade; bem como 'não geógrafos' - a exemplo de Tobias Barreto, Euclides da Cunha, Oliveira Vianna, Manoel 
Bonfim e Inácio Rangel - mas que contribuíram na elaboração de uma leitura do espaço geográfico do país. Rumando nessa direção, as abordagens vão desde a originalidade da contribuição do autor, ao discurso subjacente a Geografia por ele desenvolvida, incluindo elementos biográficos e contextuais.

Quadro 02 - Produção Acadêmica em História do Pensamento Geográfico no Brasil - 1990/1999.

\begin{tabular}{|c|c|c|c|c|}
\hline AUTOR & TRABALHO & TIPO & IES & ANO \\
\hline João Phelipe Santiago & $\begin{array}{l}\text { A Geografia no Brasil: a } \\
\text { Contribuição de Manuel Correia } \\
\text { de Andrade }\end{array}$ & Dissert. & UFPE & 1990 \\
\hline Fadel Davi Antonio Filho & $\begin{array}{l}\text { O Pensamento Geográfico de } \\
\text { Euclides da Cunha }\end{array}$ & Dissert. & $\begin{array}{l}\text { UNESP } \\
\text { (RC) }\end{array}$ & 1990 \\
\hline $\begin{array}{l}\text { Diamantino Alves C. } \\
\text { Pereira }\end{array}$ & $\begin{array}{l}\text { Origens e Consolidação da } \\
\text { Tradição Didática na Geografia } \\
\text { Escolar Brasileira }\end{array}$ & Dissert. & USP & 1990 \\
\hline $\begin{array}{l}\text { Antonio Carlos } \mathrm{R} \text {. } \\
\text { Moraes }\end{array}$ & $\begin{array}{l}\text { Bases da Formação Territorial do } \\
\text { Brasil - O Território Colonial } \\
\text { Brasileiro no "Longo" Século XVI }\end{array}$ & Tese & USP & 1991 \\
\hline $\begin{array}{l}\text { Marcos Bernadino de } \\
\text { Carvalho }\end{array}$ & $\begin{array}{l}\text { Uma Geografia de Discurso Sobre } \\
\text { a Natureza }\end{array}$ & Dissert. & USP & 1991 \\
\hline Eli Alves Penha & $\begin{array}{l}\text { A Criação do IBGE no Contexto } \\
\text { de Centralização Política do } \\
\text { Estado Novo }\end{array}$ & Dissert. & UFRJ & 1992 \\
\hline Werther Holzer & $\begin{array}{l}\text { A Geografia Humanista: Sua } \\
\text { Trajetória de } 1950 \text { a } 1990\end{array}$ & Dissert. & UFRJ & 1992 \\
\hline Inês Aguiar de Freitas & $\begin{array}{l}\text { Em Nome do Pai. A Geografia dos } \\
\text { Jesuítas no Brasil nos Séculos } \\
\text { XVI a XVIII }\end{array}$ & Dissert. & UFRJ & 1992 \\
\hline Icléia Thiesen & $\begin{array}{l}\text { Memória Institucional do IBGE: um } \\
\text { Estudo Exploratório-Metodológico }\end{array}$ & $\begin{array}{l}\text { Dissert. } \\
\text { (Ciên. da Inf.) }\end{array}$ & UFRJ & 1992 \\
\hline
\end{tabular}




\begin{tabular}{|c|c|c|c|c|}
\hline Luciana de Lima Martins & $\begin{array}{l}\text { Friedrich Ratzel Através de um } \\
\text { Prisma }\end{array}$ & Dissert. & UFRJ & 1993 \\
\hline Luiz Lopes Diniz Filho & $\begin{array}{l}\text { Território Nacional: Ideologias } \\
\text { Geográficas e Políticas Territoriais } \\
\text { no Estado Novo (1937-1945) }\end{array}$ & Dissert. & USP & 1994 \\
\hline $\begin{array}{l}\text { Vagner de Carvalho } \\
\text { Bessa }\end{array}$ & $\begin{array}{l}\text { Território e Desenvolvimento: } \\
\text { Ideologias Geográficas } \\
\text { Governo J. K. }(1956-1960)\end{array}$ & Dissert. & USP & 1994 \\
\hline Eduardo Zons Guidi & $\begin{array}{l}\text { Considerações sobre a Gênese da } \\
\text { Geografia Humana Moderna: } \\
\text { Friederic Ratzel e Paul Vidal de La } \\
\text { Blache }\end{array}$ & Dissert. & UFSC & 1995 \\
\hline $\begin{array}{l}\text { Rita de Cássia M. de S } \\
\text { Anselmo }\end{array}$ & $\begin{array}{l}\text { Oliveira Vianna e a Unidade- } \\
\text { Identidade do Espaço Brasileiro }\end{array}$ & Dissert. & $\begin{array}{l}\text { UNESP } \\
\text { (RC) }\end{array}$ & 1995 \\
\hline $\begin{array}{l}\text { Jorge Luiz Barcellos da } \\
\text { Silva }\end{array}$ & $\begin{array}{l}\text { Notas Introdutórias de um } \\
\text { ltinerário Interpretativo sobre a } \\
\text { Formação do Pensamento } \\
\text { Geográfico Brasileiro }\end{array}$ & Dissert. & USP & 1996 \\
\hline Fadel Davi Antonio Filho & $\begin{array}{|llll|}\text { A Visão } & \text { sobre a Amazônia } \\
\text { Brasileira: Uma Avaliação do } & \text { Uma } \\
\text { Pensamento Geográfico entre } \\
1900-1940\end{array}$ & Tese & $\begin{array}{l}\text { UNESP } \\
\text { (RC) }\end{array}$ & 1996 \\
\hline Jane Lúcia Rodrigues & $\begin{array}{l}\text { Uma Geografia que se Constrói: O } \\
\text { Curso de Pós-Graduação em } \\
\text { Geografia na UNESP de } \\
\text { Presidente Prudente }\end{array}$ & Dissert. & $\begin{array}{l}\text { UNESP } \\
\text { (PP) }\end{array}$ & 1996 \\
\hline Martha Martins Bordallo & $\begin{array}{l}\text { Representação } \\
\text { do Docial e } \\
\text { donálise } \\
\text { Entrevistas com } \\
\text { Fundação Instituto } \\
\text { Geografionários da } \\
\text { Grasileiro de } \\
\text { Estatística - IBGE. }\end{array}$ & Dissert. & $\begin{array}{l}\text { UERJ } \\
\text { (Educação) }\end{array}$ & 1996 \\
\hline $\begin{array}{l}\text { Genylton Odilon Rêgo } \\
\text { da Rocha }\end{array}$ & $\begin{array}{l}\text { A Trajetória da Disciplina } \\
\text { Geografia no Currículo Escolar } \\
\text { Brasileiro (1837-1942) }\end{array}$ & $\begin{array}{l}\text { Dissert. } \\
\text { (Educação) }\end{array}$ & PUC-SP & 1996 \\
\hline Perla Brígida Zusman & $\begin{array}{l}\text { Sociedades Geográficas na } \\
\text { Promoção do Saber ao Respeito } \\
\text { do Território: estratégias políticas } \\
\text { e acadêmicas das instituições } \\
\text { geográficas na Argentina (1879- } \\
\text { 1942) e no Brasil (1838-1945). }\end{array}$ & Dissert. & $\begin{array}{c}\text { USP } \\
\text { (PROLAM) }\end{array}$ & 1996 \\
\hline
\end{tabular}




\begin{tabular}{|l|l|c|c|c|}
\hline Virgínia Elisabeta Etges & $\begin{array}{l}\text { Geografia Agrária: A Contribuição } \\
\text { de Leo Waibel }\end{array}$ & Tese & USP & 1997 \\
\hline $\begin{array}{l}\text { Manoel Fernandes de } \\
\text { Sousa Neto }\end{array}$ & $\begin{array}{l}\text { Senador Pompeu: Um Geógrafo } \\
\text { do Poder No Império Do Brasil }\end{array}$ & Dissert. & USP & 1997 \\
\hline $\begin{array}{l}\text { Raquel Maria Fontes do } \\
\text { Amaral }\end{array}$ & $\begin{array}{l}\text { A Geografia e as Bases da } \\
\text { Formaçãonacional Brasileira: } \\
\text { Uma Interpretação Fundamentada } \\
\text { nas Idéias de Ignácio Rangel }\end{array}$ & Tese & USP & 1997 \\
\hline Gunther Rudzit & $\begin{array}{l}\text { O Processo de Formação do } \\
\text { Oficial do Exército Brasileiro \& a } \\
\text { Geografia (1850-1930) }\end{array}$ & Dissert. & USP & 1997 \\
\hline $\begin{array}{l}\text { Sérgio Luiz Nunes } \\
\text { Pereira }\end{array}$ & $\begin{array}{l}\text { Geografias - Caminhos e Lugares } \\
\text { da Produção do Saber Geográfico } \\
\text { no Brasil 1838-1922 }\end{array}$ & Dissert. & USP & 1997 \\
\hline José Carlos Godoy & $\begin{array}{l}\text { Evolução e Tendência do } \\
\text { Pensamento Geográfico no Brasil: } \\
\text { a Biogeografia }\end{array}$ & Livre Doc. & UNESP \\
(RC)
\end{tabular}

Fonte: Pesquisa Direta

Organização: Antônio Alfredo Teles de Carvalho - 2005/2007

No que diz respeito as instituições do saber geográfico, sobressaem as análises a propósito do IBGE (Instituto Brasileiro de Geografia e Estatística), que aparece como objeto de estudo de um expressivo número de trabalhos, 
não apenas nos cursos de Pós-Graduação em Geografia ${ }^{4}$, mas também em Ciência da Informação (THIESEN, I. UFRJ, 1992); Educação (BORDALLO, M. M. UERJ, 1996) e Memória Social (ABRANTES, V. L. C. UNIRIO, 2000; MIGUEL, N. M. D. UNIRIO, 2006). Na Geografia fora tema de uma dissertação de mestrado (PENHA, E. A. 1992) e uma tese de doutorado (ALMEIDA, R. S. 2000), ambos no PPGG da UFRJ. A Sociedade de Geografia do Rio de Janeiro - SGRJ, o Instituto Histórico e Geográfico Brasileiro - IHGB e a Associação de Geógrafos Brasileiros - AGB (ZUSMAN, P. B. USP, 1996 e PEREIRA, S. L. N. USP, 1997; 2003) também foram investigados.

A evolução do pensamento geográfico foi estudada dentre outros, por MORAES (USP, 1983), ao propor uma historia crítica desse pensamento; HOLZER, (UFRJ, 1992) quando analisou a trajetória da Geografia Humanista; GUIDI (UFSC, 1995) que discutiu a gênese da moderna Geografia Humana; SILVA (USP, 1996) ao esboçar um itinerário interpretativo sobre a formação do pensamento geográfico brasileiro; ANTONIO FILHO (UNESP/RC, 1996) ao fazer uma avaliação do pensamento geográfico no interstício 1900-1940; RODRIGUES (UNESP/PP, 1996) que analisou o Programa de Pós-Graduação em Geografia na UNESP em Presidente Prudente; e SAMPAIO (USP, 2002) ao analisar a formação e evolução da geografia acadêmica carioca.

A esses três temas, podem-se acrescentar mais dois que com freqüência têm composto a agenda dos estudiosos da historia do pensamento geográfico no país: (1) viajantes; e (2) geografia escolar, afora uma multiplicidade temática que chega mesmo a constituir um desafio na hora de propor uma classificação para tudo o que é produzido na área. O quadro seguinte (03) por si só demonstra essa realidade. Outrossim, é importante não olvidar que o mapeamento realizado e reunido nos três quadros mostrados e também no gráfico a seguir, não dá conta da totalidade das dissertações e teses produzidas ao longo desse período. Mas as que aqui constam, revelam um expressivo crescimento ao longo de quase três décadas.

\footnotetext{
${ }^{4}$ Nesse sentido, Andrade (1993, p. 61) adverte que "ao refletirmos sobre o pensamento geográfico brasileiro e o espaço nacional não devemos nos restringir apenas aos trabalhos específicos de geógrafos ou das instituições geográficas".
} 
Quadro 03 - Produção Acadêmica em História do Pensamento Geográfico no Brasil - 2000/2006.

\begin{tabular}{|c|c|c|c|c|}
\hline AUTOR & TRABALHO & TIPO & IES & ANO \\
\hline Eliseu Savério Sposito & $\begin{array}{l}\text { Contribuição à } \\
\text { Ensino } \\
\text { Geográfico do }\end{array}$ & $\begin{array}{c}\text { Tese } \\
\text { Livre Doc. }\end{array}$ & $\begin{array}{l}\text { UNESP } \\
\text { (PP) }\end{array}$ & 2000 \\
\hline $\begin{array}{l}\text { Rita de Cássia M. de S } \\
\text { Anselmo }\end{array}$ & $\begin{array}{l}\text { Geografia e Geopolítica na } \\
\text { Formação Nacional Brasileira - } \\
\text { Everardo Adolpho Backheuser }\end{array}$ & Tese & $\begin{array}{l}\text { UNESP } \\
\text { (RC) }\end{array}$ & 2000 \\
\hline $\begin{array}{l}\text { Roberto Schmidt de } \\
\text { Almeida }\end{array}$ & $\begin{array}{l}\text { A Geografia e os Geógrafos do } \\
\text { IBGE no Período de 1938-1998 }\end{array}$ & Tese & UFRJ & 2000 \\
\hline $\begin{array}{l}\text { Flaviana } \quad \text { Gasparotti } \\
\text { Nunes }\end{array}$ & $\begin{array}{l}\text { A Geografia Econômica na } \\
\text { Produção Científica Acadêmica } \\
\text { dos Programas de Pós- } \\
\text { Graduação em Geografia no } \\
\text { Estado de São Paulo (1970-1998) }\end{array}$ & Dissert. & $\begin{array}{l}\text { UNESP } \\
\text { (PP) }\end{array}$ & 2000 \\
\hline Vera Lúcia C. Abrantes & $\begin{array}{l}\text { Fragmentos de Memória das } \\
\text { Pesquisas Geográficas de } \\
\text { Campo no IBGE (1939-1968): } \\
\text { imagens e representações numa } \\
\text { abordagem da história oral }\end{array}$ & $\begin{array}{l}\text { Dissert. } \\
\text { (Mem. Soc.) }\end{array}$ & UNIRIO & 2000 \\
\hline $\begin{array}{l}\text { Charlles da França } \\
\text { Antunes }\end{array}$ & $\begin{array}{l}\text { Os Estudantes e a Construção da } \\
\text { Geografia Brasileira: um Encontro } \\
\text { nos Encontros Nacionais de } \\
\text { Estudantes de Geografia }\end{array}$ & Dissert. & UFF & 2001 \\
\hline Adriany A. Melo & $\begin{array}{l}\text { Trajetórias do Ensino de } \\
\text { Geografia no Brasil }-1978-1996\end{array}$ & Dissert. & UFU & 2001 \\
\hline $\begin{array}{l}\text { Paulo Roberto de A. } \\
\text { Bonfin }\end{array}$ & \begin{tabular}{|lrr} 
Território & e & Movimento \\
Integralista: & Uma & Contribuição ao \\
Estudo & Das & Ideologias \\
Geográficas & no & Pensamento \\
Autoritário Brasileiro & das Décadas \\
\multicolumn{2}{l}{ de 1920-1930 } &
\end{tabular} & Dissert. & USP & 2001 \\
\hline Paulo César Scarim & $\begin{array}{l}\text { Coetâneos da Crítica. Uma } \\
\text { Contribuição ao Estudo do } \\
\text { Movimento de Renovação da } \\
\text { Geografia Brasileira } \\
\end{array}$ & Dissert. & USP & 2001 \\
\hline $\begin{array}{l}\text { Alexandrina Luz da } \\
\text { Conceição }\end{array}$ & $\begin{array}{l}\text { Às Margens do Beberibe e do } \\
\text { Capibaribe: a Crítica de Tobias } \\
\text { Barreto nos Meandros da } \\
\text { Geografia }\end{array}$ & Tese & USP & 2001 \\
\hline
\end{tabular}




\begin{tabular}{|c|c|c|c|c|}
\hline $\begin{array}{l}\text { Antônio Alfredo Teles de } \\
\text { Carvalho }\end{array}$ & $\begin{array}{l}\text { Josué de Castro na Perspectiva } \\
\text { da Geografia Brasileira - } \\
\text { 1934/1956: Uma Contribuição a } \\
\text { Historiografia do Pensamento } \\
\text { Geográfico Nacional }\end{array}$ & Dissert. & UFPE & 2001 \\
\hline $\begin{array}{l}\text { Aldo Aloísio Dantas da } \\
\text { Silva }\end{array}$ & $\begin{array}{l}\text { Conexidade, } \\
\text { Geográfico de La Blache e de } \\
\text { Pierre Monbeig }\end{array}$ & Tese & USP & 2002 \\
\hline Silvia Lopes Raimundo & $\begin{array}{l}\text { A Invenção do Mito Bandeirante. } \\
\text { Tradição e Pensamento } \\
\text { Regionalista na Historiografia } \\
\text { Paulista das Décadas de 1920- } \\
1930\end{array}$ & Dissert. & USP & 2002 \\
\hline Mônica S. Machado & $\begin{array}{l}\text { A Geografia Universitária Carioca } \\
\text { e o Campo Científico - Disciplinar } \\
\text { da Geografia Brasileira }\end{array}$ & Tese & USP & 2002 \\
\hline $\begin{array}{l}\text { Renata Neder F. de } \\
\text { Souza }\end{array}$ & $\begin{array}{l}\text { A Geografia Regional na Revista } \\
\text { Brasileira de Geografia }\end{array}$ & Dissert. & UFRJ & 2003 \\
\hline $\begin{array}{l}\text { Dante Flávio da Costa R. } \\
\text { Jr. }\end{array}$ & $\begin{array}{l}\text { O Humano pelo Viés Quantitativo: } \\
\text { Um Exame do (Neo)Positivismo } \\
\text { em Speridião Faissol }\end{array}$ & 2003 & $\begin{array}{l}\text { UNESP } \\
\text { (RC) }\end{array}$ & 2003 \\
\hline $\begin{array}{l}\text { Sérgio Luiz Nunes } \\
\text { Pereira }\end{array}$ & $\begin{array}{l}\text { Sociedade de Geografia do Rio } \\
\text { de Janeiro: Origens, Obsessões e } \\
\text { Conflitos (1883-1944) }\end{array}$ & Tese & USP & 2003 \\
\hline $\begin{array}{l}\text { Flaviana } \quad \text { Gasparotti } \\
\text { Nunes }\end{array}$ & $\begin{array}{l}\text { O Econômico na Geografia - as } \\
\text { Influências do Pensamento } \\
\text { Econômico na Produção } \\
\text { Geográfica (1970-2001) } \\
\end{array}$ & Tese & $\begin{array}{l}\text { UNESP } \\
\text { (PP) }\end{array}$ & 2004 \\
\hline José Carlos da Silveira & $\begin{array}{l}\text { Da Faculdade Catarinense de } \\
\text { Filosofia à Gênese do Ensino } \\
\text { Superior de Geografia }\end{array}$ & $\begin{array}{l}\text { Dissert. } \\
\text { (Educação) }\end{array}$ & UFSC & 2004 \\
\hline $\begin{array}{l}\text { Manoel Fernandes de } \\
\text { Sousa Neto }\end{array}$ & $\begin{array}{l}\text { Planos para o Império: Os Planos } \\
\text { de Viação do Segundo Reinado } \\
\text { (1869-1889) }\end{array}$ & Tese & USP & 2004 \\
\hline Fabrício Pedroso Bauab & $\begin{array}{l}\text { Da Geografia Medieval às } \\
\text { Origens da Geografia Moderna: } \\
\text { Contrastes entre Diferentes } \\
\text { Noções de Natureza, Espaço e } \\
\text { Tempo }\end{array}$ & Tese & $\begin{array}{l}\text { UNESP } \\
\text { (PP) }\end{array}$ & 2005 \\
\hline
\end{tabular}




\begin{tabular}{|l|l|c|c|c|}
\hline Armen Mamigonian & $\begin{array}{l}\text { Estudos de Geografia Econômica } \\
\text { e de História do Pensamento } \\
\text { Geográfico }\end{array}$ & $\begin{array}{c}\text { Tese } \\
\text { Livre Doc. }\end{array}$ & USP & 2005 \\
\hline João Phelipe Santiago & $\begin{array}{l}\text { A Questão Nacional na Geografia } \\
\text { Ratzeliana e sua Assimilação no } \\
\text { Pensamento Social Brasileiro na } \\
\text { República Velha }\end{array}$ & Tese & USP & 2005 \\
\hline Mariana Araújo Lamego & $\begin{array}{l}\text { Positivismo Lógico e a Geografia: } \\
\text { Uma Interpretação entre o Círculo } \\
\text { Ve Viena e a Geografia } \\
\text { Quantitativa }\end{array}$ & Dissert. & UERJ & 2006 \\
\hline Marcos Barros de Souza & $\begin{array}{l}\text { Geografia Física: Balanço da sua } \\
\text { Produção em Eventos Científicos } \\
\text { no Brasil }\end{array}$ & Dissert. & USP & 2006 \\
\hline $\begin{array}{l}\text { Nadya Maria Deps } \\
\text { Miguel }\end{array}$ & $\begin{array}{l}\text { IBGE: construção e preservação } \\
\text { de memórias }\end{array}$ & $\begin{array}{c}\text { Dissert. } \\
\text { (Mem. Soc.) }\end{array}$ & UNIRIO & 2006 \\
\hline
\end{tabular}

Fonte: Pesquisa Direta

Organização: Antônio Alfredo Teles de Carvalho - 2005/2007 


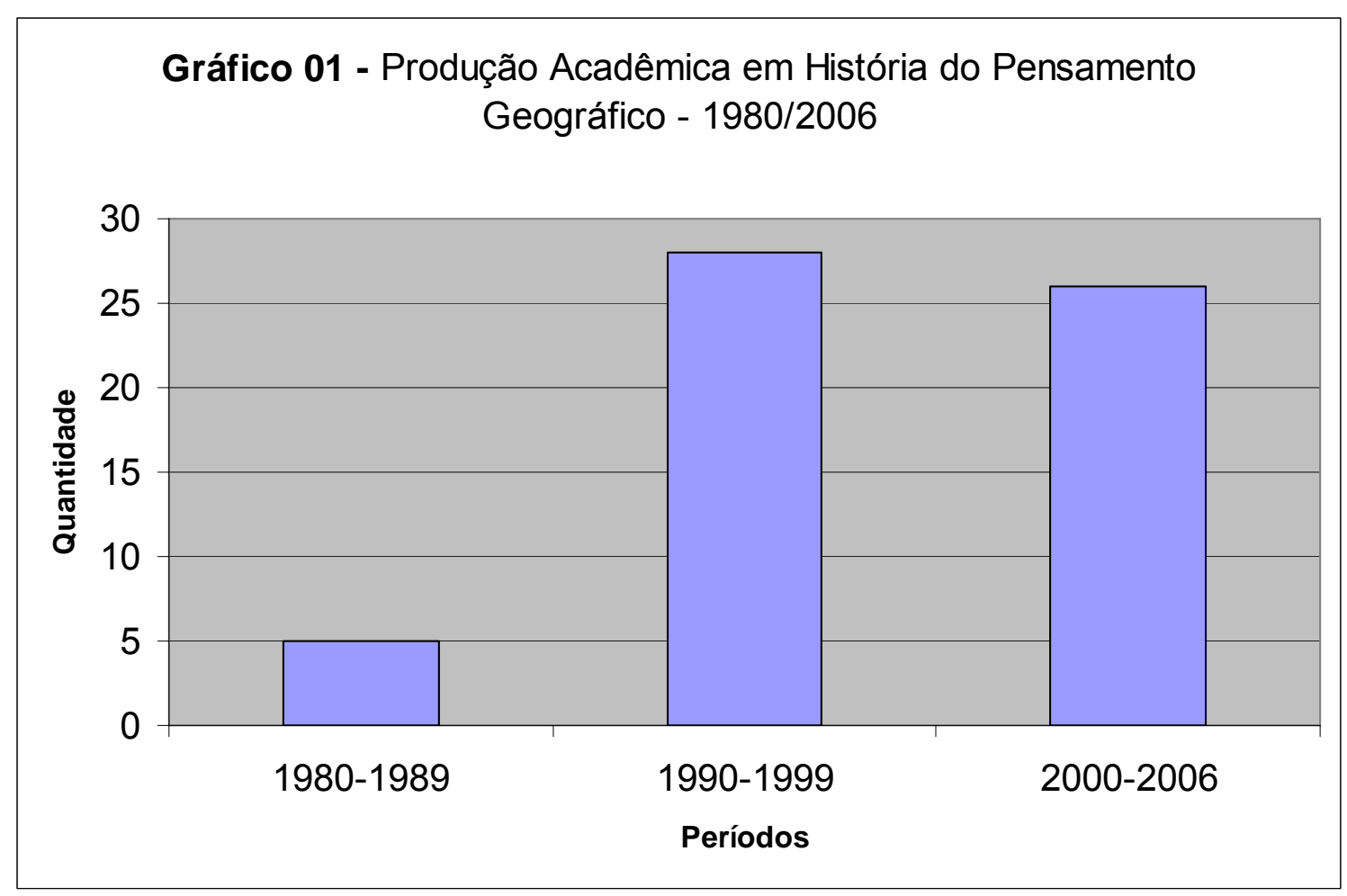

Fonte: Pesquisa Direta

Organização: Antônio Alfredo Teles de Carvalho - 2005/2007

Não se deve, aqui, deixar de destacar, que sintomaticamente, esse despertar para a necessidade de adentrar na análise da história do pensamento geográfico entre os geógrafos brasileiros vai se dar no mesmo momento em que o país começa a conhecer o processo de abertura política, após quase 20 anos de ditadura militar.

Não obstante $\mathrm{o}$ isolamento intelectual resultante desse período de exceção, desenvolveu-se aqui uma reflexão e uma crítica aos paradigmas ancorados no positivismo e no neopositivismo, por parte de uma geração de novos geógrafos militantes, que respaldados nas teses marxistas que avançaram nos debates de natureza teórica e social. Observa-se que as discussões (solitárias) iniciadas décadas atrás por Orlando Valverde, Armen Mamigonian ou Manuel Correia de Andrade, dentre outros, a partir de então, ganham um novo ímpeto.

O primeiro sintoma explícito desse processo foi o lendário Encontro Nacional da AGB, realizado na cidade de Fortaleza em 1978, marcado pela 
ruptura com o paradigma tradicional e a emergência da posteriormente denominada "Geografia Crítica". Dentro desse contexto, não se pode deixar de mencionar o retorno do Professor Milton Santos ao Brasil, depois de longo período no exílio - fundamental aos avanços alcançados a partir desse momento.

As novas luzes derivadas desses acontecimentos alavancaram o estudo e a pesquisa em história do pensamento geográfico ${ }^{5}$, que evoluiu e no limiar dos anos 90 já se afastava do teor secundário que lhe era conferido e, avançava na consolidação de uma linha de pesquisa que viria a contribuir imensamente no preenchimento das lacunas existentes na área. Depois, como bem lembra Andrade (2002, p. 132) "não se pode saber Geografia, se não se estuda a história do pensamento geográfico".

Como um exemplo desse crescimento, afora a produção aqui mostrada, também deve-se citar a realização do I Encontro Nacional de História do Pensamento Geográfico, no Instituto de Geociências e Ciências Exatas da UNESP - Rio Claro, entre os dias 09 e 12 de dezembro de 1999, que contou com 64 trabalhos inscritos de pesquisadores de diferentes partes do país, além de algumas contribuições do exterior ${ }^{6}$.

No bojo desse processo, subjacente aos contextos reconstituído, vem à luz as 'vozes esquecidas' da Geografia', seja através das instituições do saber geográfico, da história da geografia escolar, dos relatos dos viajantes, ou de eminentes mestres que compõem os anais dessa trajetória e, se constituem em

\footnotetext{
${ }^{5}$ De perspectiva historicista, o texto clássico do Professor Carlos Augusto de Figueiredo Monteiro, A Geografia no Brasil (1931-1937): Avaliação e Tendências, citado no inicio do capítulo, data desse período (1978). Tendo sido elaborado para um simpósio sobre Metodologia na Geografia dentro das atividades do também citado Encontro da AGB em Fortaleza.

${ }^{6} \mathrm{De}$ acordo com a Comissão Organizadora do evento na Apresentação dos Anais, "a relevância cientifica desse Encontro estava posta, fundamentalmente, na necessidade de reunir o que se encontrava disperso no âmbito da investigação em história do pensamento geográfico. Ao realizá-lo, pretendeu-se dar início a um esforço conjunto no sentido de rever, atualizar e aprofundar muitas visões que se constituíram à sombra do desconhecimento do passado, produzindo ou justificando práticas atuais". In: Encontro Nacional de História do Pensamento Geográfico, 1. Mesas Redondas. Rio Claro: UNESP - IGCE, 1999. Anais...

7 Expressão utilizada por Monteiro. Segundo o mesmo, no desenvolvimento desse processo, constatar-se-á, 'felizmente (ou não), que não temos sido o deserto total das idéias' (1980, p. 39).
} 
referência na análise e entendimento da mesma. Destarte, revisitar e pensar a geografia, "também é pensar forçosamente estes personagens em seus contextos", destaca Costa Gomes (1999, p. 336). E ainda, "vê-los em ação não como seres movidos por uma iluminação em busca de uma verdade transcendente, mas como atores-autores escrevendo uma narrativa, uma história, uma história da geografia (COSTA GOMES, 1999, p. 336)”.

Rumando nessa perspectiva, a pesquisa apresentada consiste num resgate da Geografia da Fome no contexto da geografia brasileira a partir da obra do geógrafo Josué de Castro em meados do século passado, conforme será visto no capítulo seguinte. 


\section{Capítulo - Delimitando e Discutindo o Objeto de Estudo à Luz da História do Pensamento Geográfico.}

A pesquisa desenvolvida consiste em um estudo na área de História do Pensamento Geográfico e contempla um recorte temporal de 21 anos. Tratando-se, portanto, de um trabalho datado, versando sobre um determinado tema, numa determinada época.

Está centrado na tese que o médico e geógrafo Josué de Castro foi o introdutor da geografia da fome na história do pensamento geográfico no Brasil a partir do segundo quartel do século passado. Mais precisamente entre 1937 e 1958. A data inicial corresponde a publicação do livro A Alimentação Brasileira à Luz da Geografia Humana, primeiro livro do autor onde a Geografia aparece como tema central ${ }^{8}$, enquanto a data limite refere-se a sua eleição para o primeiro mandato como Deputado Federal por Pernambuco, seu estado natal. E, que coincide também com o seu afastamento "definitivo" da Cátedra de Geografia Humana da Faculdade Nacional de Filosofia da Universidade do Brasil, como será visto na seqüência.

A título de contextualização faz-se mister assinalar que o recorte estabelecido compreende a um dos mais revisitados da história brasileira no século passado. Coincide com a implantação e todo o período de vigência do Estado Novo, comandado pelo Presidente Getúlio Vargas, que no dizer de Fausto (2006, p. 185), consiste na figura de maior expressão da história política brasileira do século XX. Daí a importância de revisitar a sua política e o seu significado para o país naquele interstício. Contudo,

Assinalar a duração e o impacto da figura de Vargas na história contemporânea do Brasil significa procurar compreender por que seu discurso e suas políticas, construídas no marco do pensamento autoritário dos anos 1920-40, encontraram condições tão favoráveis para se estabelecer e, sobretudo, para se transformar e perdurar na memória nacional (GOMES, 2005, p.107).

\footnotetext{
${ }^{8}$ Uma análise mais amiúde, destacando o significado deste livro no conjunto da obra do autor será desenvolvida no V Capítulo.
} 
$\mathrm{Na}$ verdade, trata-se de questões complexas e que para autora, "exigem respostas que articulem as condições vigentes nos campos político e intelectual, nacional e internacionalmente" (GOMES, 2005, p.107).

Nesse sentido, reconstituir ainda que parcialmente, os eventos de maior ressonância do panorama nacional, em consonância com a realidade mundial naquele interstício mostra-se fundamental a sua apreensão e, por conseguinte, o seu rebatimento nos desdobramentos da política varguista nos diferentes setores da vida brasileira. Ademais, não chega a ser redundante aludir, que o reconhecimento das metamorfoses processadas dentro do contexto políticoeconômico-social brasileiro de então, bem como as relações com o mundo exterior, são imprescindíveis a sua melhor compreensão.

A rigor, o decênio de 1930 é um reflexo das idéias fermentadas naquele que o precedeu, marcado por um mundo ressentido pelos efeitos da I Guerra Mundial - sobretudo o continente europeu. Com efeito, uma grande crise assolou a Europa no primeiro pós-guerra, levando-a a perda da hegemonia para os Estados Unidos da América, que beneficiados pela guerra, viu a sua economia crescer exponencialmente e os produtos procedentes da sua indústria expandir-se para o mundo. Inclusive para a América Latina, onde ampliou-se uma influência que já vinha acontecendo desde as derradeiras décadas do século XIX, em alguns casos, consistindo em ações intervencionistas, a exemplo do que acontecera em Cuba ou no Panamá. Ao mesmo tempo haviam tornado-se credores dos países envolvidos na guerra e vira New York constituir-se no maior e principal centro financeiro do mundo. Assinalando, destarte, um novo panorama geopolítico mundial.

Contudo, evidências as mais diversas, já em meados da década de 1920, prenunciavam uma crise do capitalismo, que viria a eclodir em fins da mesma, culminando com o colapso da Bolsa de Valores de New York em outubro de 1929. O que por sua vez, resultou numa grande depressão que far-se-ia sentir em diferentes partes do planeta, contribuindo dentre outras coisas, para a ascensão dos regimes totalitaristas de direita em algumas partes da Europa - a exemplo do fascismo na Itália, do nazismo na Alemanha, do franquismo na 
Espanha e do Salazarismo em Portugal - que marcaram profundamente o mundo de então ${ }^{9}$.

Inevitavelmente, esse processo ressoaria sobre a realidade brasileira, que principiava os anos 30 sob os agitos políticos de uma revolução Revolução de $1930^{10}$, que na visão de Mamigonian (2004, p. 222), assim como de grande parte dos especialistas nesse período, constitui um "acontecimento fundamental da vida brasileira, um gigantesco divisor de águas", e "rompendo" com a República Velha (Café com Leite). Mas também abalado com a grave crise econômica decorrente da queda das suas exportações, principalmente do café, que constituía a base da economia nacional. E, ainda, uma conseqüente produção agrícola sem mercado, a ruína de fazendeiros e o desemprego nas grandes cidades. Afora as dificuldades financeiras que cresciam: caía a receita das exportações e a moeda conversível se evaporara, como mostra Fausto (2006, p. 185).

É nesse contexto, mais precisamente em outubro de 1930, que Getúlio Vargas chega ao poder como chefe de um governo provisório; em seguida presidente eleito pelo voto indireto da Assembléia Nacional Constituinte de 1934, e ditador com o golpe do Estado Novo em 1937 - que se prolongaria até a sua deposição em 1945. Perfazendo, portanto, um período de quinze anos de

\footnotetext{
${ }^{9} \mathrm{E}$ iriam se refletir no Brasil, onde surgiram algumas pequenas organizações fascistas na década de 20. Porém, de acordo com Fausto (2006, p. 194), um movimento expressivo nascera nos anos 30, quando "em outubro de 1932 Plínio Salgado e outros intelectuais fundaram em São Paulo a Ação Integralista Brasileira (AIB)", que consistia numa doutrina de teor nacionalista. Combatia o comunismo, o capitalismo financeiro, sob comando dos judeus, o liberalismo e o pluripartidarismo. "Deus, Pátria e Família" constituía o lema do movimento. Ainda de acordo com Fausto (Op. Cit., p. 195), "O integralismo foi muito eficaz na utilização de rituais e símbolos: o culto da personalidade do chefe nacional, as cerimônias de adesão, os desfiles dos 'camisas verdes' ostentando o sigma $(\Sigma)$ em uma braçadeira", que não por acaso lembravam os 'camisas negras' de Mussolini.

${ }^{10}$ Ao analisar a fase que se inicia nesse momento, ressalta Sodré (1976, p. 63/4) que "o traço essencial da etapa histórica iniciada no Brasil com a Revolução de 30 é o da aceleração do desenvolvimento das relações capitalistas e, conseqüentemente, no crescimento quantitativo e qualitativo da burguesia e do proletariado. Só no campo tais relações desenvolveram-se muito desigualmente e com lentidão, pelo menos nas décadas dos trinta aos cinqüenta. A disparidade entre áreas urbanas e as áreas rurais cresce; a desigualdade de desenvolvimento entre regiões do país reflete, em parte, tal disparidade; o desenvolvimento de umas se opera em prejuízo de outras, que transferem às mais desenvolvidas a força de trabalho que as suas velhas estruturas marginalizam, enquanto se colocam como dependentes e consumidoras, semelhando colônias".
} 
poder, ao qual retornaria cinco anos depois para substituir Eurico Gaspar Dutra que fora eleito democraticamente para o mandato de 1946-1951.

A Era Vargas, mormente durante o Estado Novo, seria fortemente marcada pela dissonância que contrapunha, de um lado, a modernização e do outro, o autoritarismo ${ }^{11}$, dimanando o emblema de modernização conservadora; bem como pelo nacionalismo, materializado especialmente na política econômica, não obstante o modelo centralizador, conforme fora aludido. Entrementes, é válido acrescentar que malgrado aquilo que inicialmente se propunha, qual seja, a criação de um capitalismo nacional, ao término desse período o país encontrava-se subordinado a política de dominação dos Estados Unidos da América ${ }^{12}$.

Depois, o período que se abre com a implantação do Estado Novo não chega a constituir um rompimento com os primeiros sete anos de Vargas no poder. Segundo Fausto (Op. Cit., p. 201) "muitas de suas instituições e práticas vinham tomando forma no período 1930-1937". E complementa,

Mas a partir de dezembro de 1937, elas se integraram e ganharam coerência no âmbito do novo regime a inclinação centralizadora, revelada desde os primeiros meses após a Revolução de 1930, realizou-se plenamente. Os estados passaram a ser governados por interventores, nomeados pelo governo central e escolhidos segundo diferentes critérios. Parentes de Vargas, militares, receberam a designação. De um modo geral, porém, nos maiores Estados algum setor da oligarquia regional foi contemplado (FAUSTO, Op. Cit., p. 201).

A propósito, por mais expressivo que pudesse ser o apoio popular ao seu governo, sabia Vargas que sob certos aspectos não avançaria destituído da oligarquia cafeeira, que a despeito da crise, ainda constituía o grupo econômico mais expressivo do país. Observe-se que a própria crise lhe propiciaria os

\footnotetext{
${ }^{11} \mathrm{Na}$ verdade, o regime fora instaurado de forma autoritária e isento de grandes mobilizações. Depois, como bem lembra Fausto (2006, p. 200) o "movimento popular e os comunistas tinham sido abatidos e não poderiam reagir; a classe dominante aceitava o golpe como uma coisa inevitável e até benéfica. Congresso, que fora dissolvido submetera-se, a ponto de oitenta de seus membros irem levar solidariedade a Vargas (...) quando vários dos seus colegas estavam presos".

${ }^{12}$ A despeito da simpatia que nutria pelos totalitarismos de direita vigentes na Europa - nazifascismo e do salazarismo, quando o governo estadunidense declara guerra ao Eixo durante a Segunda Guerra Mundial, o Estado brasileiro foi obrigado a abrir mão da sua cômoda posição de neutralidade e apoiar oficialmente os Aliados. Conseqüentemente trazendo à luz mais uma dissonância do Estado Novo, que comandado por um ditador, lutara contra as ditaduras que Ihe serviram de inspiração.
} 
mecanismos de aproximação com tal grupo, ao lançar-se em sua defesa. Através do Departamento Nacional do Café (DNC) estrategicamente instituído em 1933, o governo passou a comprar a produção que diante da crise ficara sem mercado externo e passou a armazená-la, o que resultaria em grandes estoques que teriam como destino a incineração, quando não jogados ao mar.

Outrossim, outras áreas do setor seriam reorganizadas pelo governo que buscou estimular a diversificação agrícola, criando órgãos de suporte específicos, a exemplo dos Institutos (Instituto do Açúcar e do Álcool, Instituto do Mate, Instituto do Pinho etc). Em sua quase totalidade concentrados no Rio de Janeiro, então capital federal e centro aglutinador de poder, especialmente o poder público. Todavia a partir da instituição do Estado Novo a política econômica seria redirecionada e a industrialização por substituição de importações ganharia força.

Nesse sentido, a eclosão da II Guerra Mundial seria uma aliada, pois a impossibilidade de importação de maquinofaturados da Europa proporcionaria a possibilidade de um desenvolvimento industrial interno, estimulado pelo crescimento da população urbana e o conseqüente aumento do mercado consumidor e, ainda, a extinção por parte do governo, das taxas interestaduais no transporte nas mercadorias.

Assim, uma linha desenvolvimentista pragmática referendada pelo nacionalismo ganharia fôlego e passaria a constituir o paradigma a permear as discussões em torno das questões econômicas do país. Importantes órgãos e entidades são instituídos objetivando o alargamento de setores preexistentes (a exemplo dos institutos citados acima), ou aqueles direcionados à elaboração do planejamento e sua execução (Comissão de Planejamento Econômico, Coordenação de Mobilização Econômica, Carteira de Crédito Agrícola e Industrial, Conselho Nacional do Petróleo, Conselho Nacional de Geografia, etc.); grandes estatais são implantadas (Companhia Siderúrgica Nacional, Companhia Vale do Rio Doce e Companhia Hidrelétrica do São Francisco).

Ademais, o populismo que caracterizava o governo tornar-se-ia em um meio de viabilização das ações do Estado que passaria a atuar como 
coordenador e planejador econômico de uma nova sociedade brasileira. Isto é, urbano-industrial em detrimento da sua tradicional condição de agrárioexportadora.

Em meio a todo esse contexto, uma tendência esboçada desde os primórdios dos anos 30, ganha consistência, a idéia de Brasil Moderno. É a partir de então que o país trilha novas perspectivas visando adentrar no ritmo da história. No dizer de lanni (1996, p. 29), "tornar-se contemporâneo do seu tempo, organizar-se segundo os interesses dos seus setores sociais mais avançados". Com efeito,

O que se encontrava em esboço, apenas intuído, de repente parece clarificarse. Foi na década de 30 que se formularam as principais interpretações do Brasil Moderno, configurando "uma compreensão mais exata do país". Muito do que se pensou antes se polariza e se decanta nessa época. E muito do que se pesa depois arranca das interpretações das formulações formuladas então. (IANNI, Op. Cit., p. 29).

É o momento em que de acordo com a periodização da historiografia brasileira proposta por Mota (1994), dá-se a redescoberta do Brasil ${ }^{13}$. Que conforme aponta, pode ser comprovada na evolução de algumas obras historiográficas que vieram à luz após a Revolução de 1930, e que modificaram as releituras da realidade brasileira - já arranhadas pela intelectualidade que emergia em 1922, com a Semana de Arte Moderna, de um lado, e com a fundação do Partido Comunista, de outro. Constituído-se dessa forma, em dois fatores fundamentais para os desdobramentos que iriam processar-se no campo político-cultural a partir de 1930.

Então, as matrizes da formação nacional são revistas e analisadas sob uma nova perspectiva e, nesse sentido há por parte dos historiadores, bem como daqueles que se detêm ao estudo do pensamento social brasileiro, uma quase unanimidade em considerar três obras como marcos desse processo: (1) Evolução Política do Brasil, de Caio Prado Junior. Para Mota (Op. Cit., p. 28), "algo novo naquele momento em face a interpretação materialista. Com a

\footnotetext{
${ }^{13}$ Mota aponta cinco momentos que considera decisivos ao abordar a ideologia da cultura brasileira no período que estende-se de 1933 a 1974: Redescobrindo o Brasil - 1933 -1937; Primeiros Frutos da Universidade - 1948 -1951; Era de Implicação e Revisão Reformista 1957 - 1964; Revisões Radicais - 1964 - 1969; Impasses da Independência - 1964 - 1974
} 
interpretação de Caio Prado Júnior, as classes emergem pela primeira vez nos horizontes de explicação da realidade social brasileira - enquanto categoria analítica"; (2) Casa Grande \& Senzala, de Gilberto Freyre, igualmente publicada no mesmo ano da obra anterior. De estilo corrente e anticonvencional, está centrado em teses veiculadas sobre relações raciais, sexuais e familiares. De abordagem inspirada na Antropologia Cultural norteamericana e pelo uso de fontes até então não consideradas. Contrapõe -se as teses de Oliveira Vianna, que considerava de forma negativa a mestiçagem, considerando-a de forma positiva (MOTA, Op. Cit., p. 29); e (3) Raízes do Brasil, de autoria de Sérgio Buarque de Hollanda, publicada três anos depois e trazia em seu bojo a crítica (talvez demasiado erudita e metafórica para o incipiente e abafado ambiente cultural e político da época) ao autoritarismo e às perspectivas hierárquicas sempre presentes nas explicações do Brasil.

Por sua vez, a essas, lanni (Op. Cit., p. 30) acrescenta outras obras de "alguns homens dotados de uma formação nova e de uma técnica intelectual mais adequada à compreensão dos problemas da cultura, da sociedade e da história". Revelam horizontes novos no desenvolvimento brasileiro. É o caso dentre outros de Roberto Simonsen (Evolução Industrial do Brasil), Manoel Bomfim (Brazil Nação), Nestror Duarte (A Ordem Privada e a Organização Política Nacional), Azevedo Amaral (A Aventura Política do Brasil), Mario Travassos (Projeção Continental do Brasil), Barbosa Lima Sobrinho (A Verdade sobre a Revolução de Outubro), Afonso Arinos de Mello Franco (Conceito de Civilização Brasileira) e Paulo Prado (Paulística).

É perceptível nas considerações de lanni, afora os novos horizontes subjacentes aos autores e obras elencadas, um certo otimismo com relação a um quadro de referência nacional, que então começava a projetar-se. Por conseguinte, as explicações fundamentadas nas teorias deterministas de autores como Oliveira Vianna, Silvio Romero e Nina Rodrigues, utilizadas para justificar o atraso brasileiro passam a ser questionadas veementemente. Ademais, é importante perceber que essas releituras do país assinalam significativas mudanças, expressas no deslocamento da organização e desenvolvimento social. A guisa de exemplo, Gilberto Freyre, vê a história na 
perspectiva da vigorosa matriz representada pelo Nordeste, por sua importância e história ao longo da Colônia e do Império; enquanto Caio Prado Jr. e Roberto C Simonsen não escondem que vêem a história do Brasil na perspectiva da matriz que está se criando em São Paulo.

Em meio a essa realidade o país vira nascer, dentro de um sistema educacional $^{14}$ caracterizado pelo autoritarismo conservador, as suas duas primeiras universidades. Pois como bem ressalta Monteiro (2002, p. 1) "diferentemente da colonização espanhola, implantadora de Universidades no Novo Mundo Americano, a portuguesa disso não se ocupou". Assim, só em 1934 seria implantada a primeira universidade brasileira, a Universidade de São Paulo - USP, e no ano seguinte a Universidade do Distrito Federal - UDF, no Rio de Janeiro.

Com a emergência da universidade dar-se-ia a institucionalização da Geografia, inicialmente na Universidade de São Paulo, dentro da sua Faculdade de Filosofia, Ciências e Letras, onde fora implantado o primeiro curso no Brasil. Sendo, portanto pioneira, e historicamente a maior responsável pelo desenvolvimento das investigações e estudos geográficos e, por isso mesmo, segundo Pereira (1994, p. 438), responsável pela "grande missão de preparar professores de geografia para o curso secundário, e, concomitantemente, encaminhar seus alunos para a pesquisa geográfica no campo".

Porém é importante lembrar que para tanto houve a necessidade de recorrer a vinda de mestres estrangeiros com formação na área, para formar as primeiras gerações de profissionais. Observe-se que naquele momento cabia especialmente, aos advogados e engenheiros ministrar aulas de Geografia no ensino médio ou em algum curso de nível superior que oferecesse a disciplina. Assim, quando da implantação da Universidade de São Paulo, as missões culturais européias propiciariam a vinda de mestres ou futuros mestres para o

\footnotetext{
${ }^{14}$ A política educacional de Vargas ficara nas mãos de jovens políticos mineiros, iniciados na velha oligarquia do estado e que tomariam outros rumos a partir de 1930. "É o caso de Francisco Campos, ministro da Educação até 1932, e do seu substituto, Gustavo Capanema, que permaneceu no ministério de 1934 a 1945" (FAUSTO, Op. Cit., p. 188).
} 
Brasil ${ }^{15}$. Com a primeira missão francesa viera Pierre Deffontaines, que chega a São Paulo em 1934 com a responsabilidade de implantar a Cadeira de Geografia do curso de Geografia e História da Faculdade de Filosofia, Ciências e Letras. Assim o fez, e no ano subseqüente parte para o Rio de Janeiro com a mesma finalidade. Assim, vai repetir na nascente Universidade do Distrito Federal o que fizera na capital paulista.

Essa transferência de Deffonteines resultaria na vinda de um outro francês para assumir o lugar por ele deixado. Trata-se de Pierre Monbeig, que por onze anos permaneceu no Brasil e assim, formou as primeiras gerações de geógrafos de São Paulo. No decorrer desse tempo deu continuidade e solidificou o trabalho iniciado por seu patrício, tornando-se doravante um ícone da Escola Paulista de Geografia (e da geografia brasileira, evidentemente). Com Monbeig teve inicio o doutoramento em Geografia no Brasil. Sob a sua orientação, em 1944, Maria da Conceição Vicente de Carvalho defende e primeira tese de doutorado em Geografia no Brasil - Santos e a Geografia Humana do Litoral Paulista. O quadro a seguir mostra as primeiras teses de doutorado em Geografia na Universidade de São Paulo. Todas orientadas por Monbeig.

Quadro 04 - Teses de Doutoramento Orientadas por Pierre Monbeig

\begin{tabular}{|l|l|c|}
\hline \multicolumn{1}{|c|}{ AUTOR } & \multicolumn{1}{|c|}{ TESE } & DEFESA \\
\hline $\begin{array}{l}\text { Maria Conceição } \\
\text { Vicente de Carvalho }\end{array}$ & Santos e a Geografia Humana do Litoral Paulista & $23 / 11 / 1944$ \\
\hline Ary França & Estudo sobre Clima da Bacia de São Paulo & $16 / 11 / 1945$ \\
\hline Nice Lecoc Müller & Sítios e Sitiantes & $22 / 11 / 1946$ \\
\hline João Dias da Silveira & $\begin{array}{l}\text { Estudo Geográfico dos Contrafortes Ocidentais da } \\
\text { Mantiqueira }\end{array}$ & $-------/ 1946$ \\
\hline $\begin{array}{l}\text { Renato Silveira } \\
\text { Mendes }\end{array}$ & Paisagens Culturais da Baixada Santista & $23 / 10 / 1948$ \\
\hline
\end{tabular}

Fonte: http//www.geografia.fflch.usp.br

Organização: Antônio Alfredo Teles de Carvalho

15 Conforme Mota (Op. Cit., p. 33), Não será exagero afirmar que "muitas carreiras universitárias de europeus (franceses notadamente) tiveram nestes 'tristes trópicos' seu início". Dentre os nomes que aqui desembarcaram através dessas missões, estão Fernand Braudel, Claude Lévi-Strauss, Pierre Monbeig, Roger Bastide, Ungaretti, criando uma tradição de raízes profundas e fisionomia marcada. 
No Rio de Janeiro a Universidade do Distrito Federal teria vida curta, pois com o advento do Estado Novo seria dissolvida e passaria a constituir a Faculdade Nacional de Filosofia da Universidade do Brasil, instituída pela Lei $n^{\circ} 452$ de 05 de julho de 1937. Ali, assim como ocorrera na Universidade de São Paulo, seja na UDF ou na FNF/UB, o curso implantado fora Geografia e Historia. Essa junção reproduzia o modelo francês tradicional, que segundo Geiger, (1988, p. 61), "refletia certa influência do pensamento de Ritter. Discípulo de Hegel, era ele um dialético idealista que, opondo-se à lógica formal kantiana, encarava os fatos geográficos numa perspectiva de processo".

A atuação dos dois mestres franceses, acrescida de Francis Ruellan igualmente francês, foi fundamental para o desenvolvimento da Geografia no Brasil. Ruellan, que aqui chegara em 1940 como adido militar e coordenador das relações militares do seu país no continente, até 1956 esteve ligado a Universidade do Brasil e ao Conselho Nacional de Geografia, na condição de consultor técnico, dedicando-se ao ensino e a pesquisa, especialmente em Geomorfologia, sua especialidade, e constituindo-se em uma das maiores referências da geografia carioca ${ }^{16}$. Porém, adverte ABREU (1994, p. 2002) que

Embora seja inegável que, com a criação dos cursos universitários, a geografia atingiu um patamar novo em seu processo de desenvolvimento no Brasil, fixar o seu nascimento em meados da década de 30 acaba por encobrir o importante papel que vinha desempenhando, já há 25 anos, aquele que foi o verdadeiro introdutor da chamada escola francesa no país: Carlos Delgado de Carvalho.

Nascido na França, filho de pais brasileiros, Delgado de Carvalho é apontado por inúmeros autores como introdutor do país no circuito dos modernos conhecimento geográficos e, por isso mesmo, identificado como um marco para a moderna geografia científica no país.

\footnotetext{
${ }^{16}$ Ao falar sobre a influência de Francis Ruellan na geografia destaca Bernardes, (1982, p. 522), que o mesmo também ensinou em outros centros como São Paulo. Foi outra personalidade cujo entusiasmo cativou dezenas de discípulos e sobre os quais exerceu influência em graus variados. Despertou um grande numero deles para a pesquisa e os encaminhou na profissionalização, em uma época ainda de incertezas quanto ao futuro prático do novo - novo entre nós, brasileiros - campo disciplinar. Ele formou o que poderíamos chamar a segunda geração de geógrafos no Rio de Janeiro.
} 
A permanência desses mestres no país, mais a passagem menos duradoura ou simples visitas de outros tantos, a exemplo de Emmanuel De Martonne, Pierre Gourou e, mais adiante, Jean Tricart, Michel Rochefort e Jacqueline Beaujeau-Garnier, dimanou e difundiu no país uma geografia calcada na "orientação da Escola Francesa sob a égide lablachiana" (Monteiro, 1980, p. 14) que aqui predominou do decênio de 1930 até meados de 1950. Momento em que se realiza no Rio de Janeiro, o XVIII Congresso Internacional de Geografia sob os auspícios da União Geográfica Internacional - UGI. Onde já é possível perceber indícios de mudanças no que se refere ao paradigma vidalino.

Contudo convém não esquecer o papel desempenhado pelo geógrafo alemão Leo Waibel, que permaneceu no Brasil durante toda a segunda metade do decênio de 1940. Contratado pelo Conselho Nacional de Geografia - CNG como assistente técnico, desenvolveu pesquisas que "renovaram e inovaram temas e abriram novas direções para o estudo da geografia brasileira" (BERNARDES, Op. Cit., p. 523). Para Monteiro (1980, p. 14). "A influência norte-americana menos clara, não é desprezível". Hartshorne (1939) já faz sentir os ecos de suas preocupações sobre a 'essência' da geografia. A abordagem de Preston James (Outline of Geography) sobre os gêneros de vida nas grandes paisagens vegetais do globo é, sobretudo visível no Rio.

$\mathrm{Na}$ esteira desse processo, cada um deixou a sua contribuição na formação de uma cultura geográfica no país, fazendo germinar, crescer, florescer e frutificar a semente lançada por Deffontaines, que "ligou definitivamente o seu nome à moderna orientação dos estudos geográficos no Brasil" (PEREIRA, Op. Cit., p 438). Suas atividades perpassaram a esfera da Faculdade de Filosofia, Ciências e Letras da Universidade de São Paulo para um universo mais amplo através de uma série de grandes realizações. Dentre as quais a criação da Associação dos Geógrafos Brasileiros - AGB, no dia 17 de setembro de 1934, conforme atesta a sua ata de fundação (Quadro 5). Repetia-se aqui o que era freqüente na Europa, onde após a criação dos cursos de universitários de Geografia, surgiam novas sociedades de profissionais independente daquelas já existentes (GEIGER, Op. Cit., p. 667). 


\section{Quadro 05 - ATA DE FUNDAÇÃO DA AGB}

"Em 17 de setembro de 1934, à Av. Angélica, 133, os Srs. Pierre Deffontaines, Luiz Flores de Moraes Rego, Rubens Borba de Moraes e Caio Prado Jr, resolveram os presentes fundar uma sociedade de estudos geográficos denominada Associação dos Geógrafos Brasileiros. Esta Associação terá por fim:

10. Reuniões periódicas dos membros com exposição de um assunto de Geografia brasileira por um do membros, seguida de discussão.

$2^{\circ}$. Organização de excursões em comum para estudo de uma questão.

$3^{\circ}$. Constituição de uma biblioteca especializada em Geografia, por colaboração dos membros e doações (livros, revistas e cartas).

O Sr. Caio Prado Junior foi indicado para secretário, cabendo-Ihe redigir as atas e ficando a seu cargo os demais serviços da secretaria.

Para presidente foi indicado o Prof. Pierre Deffontaines. Para tesoureiro o sr. Rubens Borba de Moraes. A organização da biblioteca e do fichário com indicação de todos os livros, revistas e cartas existentes nas bibliotecas de São Paulo ficou a cargo dos srs Rubens Borba de Moraes e Caio Prado Junior.

As reuniões serão realizadas na primeira e terceira segunda feira de cada mês, às 20 horas e meia na residência do Prof Deffontaines - Av Angélica, 133. A primeira reunião ordinária fica fixada para o dia $1^{\circ}$ de Outubro.

As reuniões se comporão de duas partes: 10. Exposição e discussão. A exposição durará no máximo meia hora. $2^{\circ}$. Relatório de livros e artigos de Geografia. As comunicações poderão ser feitas em português ou francês.

As contribuições dos membros serão recolhidas pelo tesoureiro. Cada membro terá completa liberdade para fixação da sua quota. Caberá ao tesoureiro indagar de cada um, individualmente, o montante de sua contribuição.

Foram propostos e aceitos como objetivos a serem tratados, os seguintes assuntos:

$1^{\circ}$. Esquema de um programa para o estudo do sólo em S. Paulo, pelo sr Moraes Rego - $1^{\circ}$. de Outubro.

$2^{\circ}$. Etapas do povoamento de S. Paulo no XVI e XVII secs. pelo sr. Rubens de Moraes - 6 de Novembro.

$3^{\circ}$. As fórmas karsticas no vale do Ribeira do Iguape, pelo sr. Moraes Rego. Data a ser fixada.

4․ Ensaio dos tipos de povoamento no Estado de S. Paulo, pelo Prof Deffontaines. 15 de Novembro, digo Outubro.

50. Ensaio de divisão regional de S. Paulo, pelo Prof Deffontaines. Data a ser fixada.

$6^{\circ}$. Contribuição ao estudo da repartição da propriedade fundiária rural no Est. de S. Paulo, pelo sr. Caio Prado Junior. 19 de Novembro.

Ficou deliberado que os novos membros da Associação seriam indicados de comum acordo, pelos membros efetivos.

E para constar, eu, secretario, redigi esta ata que vai assinada pelos membros fundadores presentes.

CAIO PRADO JR

LUIZ FLORES DE MORAES REGO

PIERRE DEFFONTAINES

RUBENS BORBA DE MORAES

Fonte: http://www.agb.org.br. Acessado em 12 de dezembro de 2006. 
Não demorou muito para que a Associação que nasceu ligada ao curso de Geografia e História da Faculdade de Filosofia Ciências e Letras, e reuniu inicialmente não apenas Pierre Deffonatines e seus alunos de Geografia e História, mas também grandes intelectuais como Caio Prado Júnior, Luiz Flores de Moraes Rego e Rubens Borba de Moraes (como mostra a sua ata de fundação), segundo pode ser visto na sua ata de fundação, tomasse uma dimensão nacional e se "constituísse desde o início num lugar mais criativo do que o próprio Curso de Geografia e História" (MAMIGONIAN, 1991, p. 158).

A despeito da denominação, ao longo dos seus primeiros dez anos foi uma entidade meramente paulista. Só a partir de 1944 após um acordo com os geógrafos cariocas tornar-se-ia nacional, o que se concretizaria na Assembléia Geral realizada em Lorena (SP) no ano seguinte. Porém, em sua organização a

Associação foi profundamente aristocrática, para não dizer oligárquica e estabeleceu duas categorias de sócio: os efetivos, com direitos plenos, e os cooperadores, todas as pessoas interessadas pelo estudo da Geografia sem todavia terem uma obra específica na área. Em geral, o sócio se iniciava como cooperador e só passava a efetivo se os efetivos resolvessem elegê-lo para o 'clube fechado'. Este sistema tinha dois fins: 1- evitar que intelectuais não geógrafos chegasse a posições de controle e direção da sociedade a nível nacional; 2- fazer uma espécie de patrulhamento científico, a fim de que a sociedade mantivesse, até certo ponto, uma linha uniforme de pensamento. Evitava-se, assim de uma só vez, os aventureiros, os incompetentes e os que tinham divergências epistemológicas e metodológicas (ANDRADE, 1993, p. $65)$.

Tinha nas Assembléias Gerais, realizadas anualmente, o seu ponto alto (mais de vinte entre 1945 e 1969, como mostra a tabela da página seguinte). Aí eram apresentadas e debatidas teses e comunicações, além dos estudos de campo na cidade sede do evento e adjacências, proporcionando, dessa forma, uma maior difusão da geografia que se produzia nos diversos recantos do país, que crescia com a implantação das Faculdades de Filosofia que se disseminava pelas principais cidades do país.

Tão significativo fora o papel desempenhado pela AGB na formação do pensamento geográfico brasileiro, que a partir da realização das mencionadas assembléias, 'tornou 'venerandas' as sociedades de geografia que the antecederam, algumas existentes há bastante tempo" (ABREU, Op. Cit., 217). 
Quadro 06 - Assembléias Gerais da AGB (1945 - 1969)

\begin{tabular}{|c|c|c|}
\hline ORDEM & ANO & LOCAL \\
\hline $1^{\mathrm{a}}$ & 1945 & São Paulo - SP \\
\hline $2^{\mathrm{a}}$ & 1946 & Lorena - SP \\
\hline $3^{a}$ & 1947 & Rio de Janeiro - RJ \\
\hline $4^{a}$ & 1948 & Goiânia - GO \\
\hline $5^{a}$ & 1950 & Belo Horizonte - MG \\
\hline $6^{a}$ & 1951 & Nova Friburgo - RJ \\
\hline $7^{a}$ & 1952 & Campina Grande - PB \\
\hline $8^{a}$ & 1953 & Cuiabá - MT \\
\hline $9^{a}$ & 1954 & Ribeirão Preto - SP \\
\hline $10^{\mathrm{a}}$ & 1955 & Garanhuns - PE \\
\hline $11^{a}$ & 1956 & Rio de Janeiro - RJ* \\
\hline $12^{\mathrm{a}}$ & 1957 & Colatina - ES \\
\hline $13^{a}$ & 1958 & Santa Maria - RS \\
\hline $14^{\mathrm{a}}$ & 1959 & Viçosa - MG \\
\hline $15^{\mathrm{a}}$ & 1960 & Mossoró - RN \\
\hline $16^{a}$ & 1961 & Londrina - PR \\
\hline $17^{\mathrm{a}}$ & 1962 & Penedo - AL \\
\hline $18^{a}$ & 1963 & Jequié - BA \\
\hline $19^{a}$ & 1964 & Poços de Caldas - MG \\
\hline $20^{a}$ & 1965 & Rio de Janeiro - RJ** \\
\hline $21^{a}$ & 1966 & Blumenau - SC \\
\hline $22^{\mathrm{a}}$ & 1967 & Franca - SP \\
\hline $23^{a}$ & 1968 & Montes Claros - MG \\
\hline $24^{a}$ & 1969 & Vitória - ES \\
\hline
\end{tabular}

Fonte: ABREU, Maurício de Almeida, 1999, p. 222/3

*Reunião Administrativa. Neste ano realizou-se no Rio de Janeiro o XVIII Congresso Internacional de Geografia sob os auspícios da União Geográfica Internacional.

**Não houve trabalho conjunto, apenas excursões. 
Assim, a AGB foi de grande importância naquele momento, especialmente por constituir-se numa entidade cultural que também era ponto de encontro dos novos profissionais, espaço de troca de idéias e debates, divulgação de trabalhos, confronto de correntes e dos seus valores políticos. Juntamente com o Conselho Nacional de Geografia (CNG), alavancaram o processo de consolidação e desenvolvimento da geografia no Brasil iniciado pelas Faculdades de Filosofia.

O Conselho Nacional de Geografia (CNG) foi criado por decreto do Governo Federal em 24 de março de 1937, sendo assim, um ato do Estado Novo, conforme evidenciado anteriormente. Nascera com algumas atribuições, a exemplo do levantamento da carta do Brasil ao milionésimo e o planejamento e realização do censo demográfico de 1940. Ademais, compunha o projeto varguista de conhecimento e controle do território nacional, ao mesmo tempo em que contribuía à materialização o paradigma da 'modernização' em que adentrava o país, amplamente difundido pelo Governo, e que fazia-se sentir, inclusive entre a classe intelectual da época ${ }^{17}$. Fora implantado dentro do Conselho Nacional de Estatística, criado em 1934 (mas só instalado dois anos depois). Em 1938 passariam a formar um único órgão, o IBGE - Instituto Brasileiro de Geografia e Estatística ${ }^{18}$, autarquia subordinada a Presidência da Republica.

Mas a criação do CNG também consistiu na atuação da União Geográfica Internacional - UGI, no jogo hegemônico através da difusão de idéias, cultura, técnicas; visto que anos antes, De Martonne, seu presidente, estivera no Brasil e solicitara a adesão do país a mesma (GEIGER, Op. Cit., p. 62). Por

\footnotetext{
${ }^{17}$ A propósito, em seu texto clássico, escrito em meados de 1950, destacara Pereira (Op. Cit., p. 448): “... pode hoje o Brasil considerar-se um dos Estados modernos, onde a investigação geográfica figura na base dos planejamentos oficiais e onde os geógrafos são tratados como profissionais amparados por uma boa formação científica e atuam sob proteção de dispositivos legais, claramente definidos e regulamentados".

${ }^{18}$ Com efeito, assinala Monteiro (Op. Cit., p. 10) que "Ligada a um caráter pragmático de subsídio político, a produção ibegeana de geografia, em contraste com aquela da nascente universidade, revestiu-se de um caráter de comprometimento ao poder o que fez com que se a distinguisse (mesmo com um certo tom de malícia) como 'Geografia do Estado Novo', passando posteriormente o epíteto à oficial".
} 
conseguinte, do ponto de vista formal, a fundação do CNG foi para servir de instrumento a esta adesão ${ }^{19}$.

Independente de sua 'função ideológica', tornou-se um grande centro de estudos geográficos e disseminador da Geografia produzida no país, através dos levantamentos demográficos, mapeamentos, cursos ministrados, além de dois dos mais importantes periódicos da história da geografia nacional: a Revista Brasileira de Geografia - RBG que entrou em circulação em 1939 e o Boletim Geográfico - BG que circulou de 1947 até 1978 quando foi extinto.

Trilhando esse percurso nasceu e desenvolveu-se a Geografia no Brasil $^{20}$. Porém, dentro dessa trajetória convém não olvidar a contribuição de grandes mestres brasileiros, a exemplo de Arthur Ramos, Alberto Lamego, Victor Ribeiro Leuzingner e Josué de Castro, dentre outros, que tiveram significativa importância nesse processo ${ }^{21}$. Não por acaso, ao esboçar uma periodização do pensamento geográfico brasileiro, no interstício entre 1946 e 1964, ressalta Dias (1989, p. 197) "não saberíamos como esclarecer esta passagem sem destacar a contribuição original de Josué de Castro".

Na verdade, Josué ganhará notoriedade por trazer à luz um tema inédito, atípico e até, pode-se afirmar, antigeográfico em meio a geografia praticada na sua época ${ }^{22}$. Trata-se da fome, seu tema de estudo ao longo da vida, e do qual viria a tornar-se uma das maiores autoridades mundiais. No prefácio do livro Homens e Caranguejos, Josué relata os seus primeiros contatos com a fome nos alagados da capital pernambucana. Diz Josué:

\footnotetext{
${ }^{19}$ Para Geiger (Op. Cit., p. 62), "Depois de ter contribuído para a expansão política econômica de cada país, o campo geográfico do centro promoveu novas formas de organização e criou a União Geográfica Internacional - UGI. Um sinal da marcha do mundo para novas fases prenunciadoras da globalização".

${ }_{20}$ Faz-se, aqui, necessário, deixar evidente, que está se fazendo alusão a geografia acadêmica. Ou, como preferem alguns autores que discorreram sobre o tema, a exemplo de Andrade (2002, p. 135), 'geografia científica'; ou ainda, 'moderna geografia brasileira' no dizer de Mamigonian (2004, p. 1).

${ }^{21}$ Mas que de acordo com Mamigonian (2004, p. 1) foram obscurecidos pelo processo desencadeado pela liderança dos mestres franceses mencionados, dado o complexo de inferioridade característico da cultura brasileira da época. Conseqüentemente, não tiveram uma influência compatível com a sua importância na moderna geografia nascente no Brasil.

${ }^{22}$ Maiores considerações a propósito das concepções geográficas de Josué de Castro serão desenvolvidas nos capítulos $\mathrm{V}$ e VI.
} 
Não foi na Sorbonne, nem em qualquer outra universidade sábia, que travei conhecimento como o fenômeno da fome. O fenômeno se revelou espontaneamente a meus olhos nos mangues do Capibaribe, nos bairros miseráveis da cidade: Afogados, Pina, Santo Amaro, Ilha do Leite. Esta é que foi a minha Sorbonne: a lama dos mangues do Recife, fervilhando de caranguejos e povoada de seres humanos feitos de carne de caranguejo, pensando e sentindo como caranguejo (...) Seres humanos que se faziam assim irmãos de leite dos caranguejos (CASTRO, 2001, p. 10).

Nasceu no dia 05 de setembro de 1908 na cidade do Recife. Cidade dos rios, das pontes e das antigas residências palacianas; também cidade dos mocambos. Segundo o autor,

Nasci numa rua que tinha o nome ilustre de Joaquim Nabuco, o grande abolicionista dos escravos nos tempos do Império. A casa que nasci tinha ao lado um grande viveiro de peixes, de caranguejos, e siris. Se não nasci mesmo dentro do viveiro, com os caranguejos, já com dois anos estava dentro dele (CASTRO, 2001, p. 16).

E, mais adiante, continua relatando a infância às margens do Rio

Capibaribe ao mesmo em que recupera as suas origens...

Criei-me nos mangues lamacentos do Capibaribe, cujas águas fluindo diante dos meus olhos ávidos de criança, pareciam estar sempre a me contar uma longa história. O romance das longas aventuras de suas águas descendo pelas diferentes regiões do Nordeste: pelas terras cinzentas do Sertão seco, onde nasceu meu pai e de onde emigrou da seca de 1877 com toda a família, e pelas terras verdes dos canaviais da Zona da Mata, onde nasceu minha mãe, filha de senhor de engenho (CASTRO, 2001, p. 18).

Esse contato precoce com os mangues do Capibaribe despertou-lhe para a miséria que assolava especialmente as populações ribeirinhas da capital pernambucana. Na sua concepção os mangues do Capibaribe constituem o paraíso dos caranguejos, onde tudo é, foi ou está para ser caranguejo, inclusive a lama e o homem que nela vive. Rumando nessa perspectiva desenvolveu a teoria do Ciclo do Caranguejo:

A lama misturada com urina, excrementos e outros resíduos que a maré traz, quando ainda não é caranguejo, vai ser. O caranguejo nasce nela, vive dela. Cresce comendo lama, engordando com as porcarias dela, fazendo com lama a carninha branca de suas patas e a geléia esverdeada de suas vísceras pegajosas. Por outro lado o povo daí vive de pegar caranguejo, chupar-lhes as patas, comer e lamber os seus os seus cascos até que fiquem limpos como um copo. E com a sua carne feita de lama fazer a carne do seu corpo e a carne do corpo de seus filhos (...) O que o organismo rejeita, volta como detrito, para a lama do mangue, para virar caranguejo outra vez (CASTRO, 1968, p. 26). 
Tal teoria aparece como uma luz a alumiar os seus primeiros escritos sobre alimentação, quase sempre centrados na cidade do Recife. Desde então trilhou pelos meandros do entendimento do espectro da fome em diferentes escalas, analisando-a como conseqüência dos processos sócio-econômicos.

Em 1929, aos vinte e quatro anos, se forma médico pela Faculdade Nacional de Medicina, no Rio de Janeiro, depois de cursar os dois primeiros na Faculdade de Medicina da Bahia. Onde tivera, "a princípio uma impressão de deslumbramento e de veneração por seus velhos muros, pela austera fachada da sua escola e, depois, desencanto no que diz respeito ao ensino ministrado" (A. M. CASTRO, 2003, p. 17) ${ }^{23}$. Igual sentimento se repetiria no Rio de Janeiro, quando se desapontara por completo ${ }^{24}$, paradoxalmente ao contato com alguns colegas $^{25}$, seja nesse momento ou nos tempos em que permaneceu na capital baiana. Conforme conta, em Salvador, os rumos dos seus estudos tivera significativa influência de dois colegas residentes na mesma pensão em que morava, e com os quais mantivera um contato mais amiúde - Arthur Ramos e Teotônio Brandão. Segundo ele,

Teotônio com mais intimidade, Ramos com uma certa distância e reserva diante de sua maior maturidade intelectual, do seu prestígio de veterano, com três anos de curso na frente. Com Teotônio, discutíamos, com Ramos ouvíamos. E ouvíamos coisas esmagadoras. Nomes arrevesados de venerandos sábios alemães (...) Ficamos de queixo caído diante da imponência da sua cultura (A. M. CASTRO, 2003, p. 17) ${ }^{26}$.

\footnotetext{
${ }^{23}$ Entretanto rendia louvores àqueles que lhe causaram entusiasmo. $E$ esse foi o caso do Mestre Pirajá da Silva, segundo ele "figura veneranda de homem de estudo, e professor de Fisiologia" e Aristides Novis que the arrebatara muitas vezes "com o brilho literário de suas preleções". Assim, afirmara "virei 'fisiólogo' em dois tempos. Estudei com furor, conquistei uma distinção na cadeira e uma amizade do mestre que perdurou até a sua morte" (A. M. CASTRO, 2003, p. 17).

${ }^{24}$ A propósito, relatara, "entrei com um grande entusiasmo e saí com interesse quase morto pela maioria dos assuntos, na forma em que eram apresentados. Poucos professores me entusiasmaram (...) A grande figura que me encheu de encantamento foi a do Professor A. Austregésilo, sem dúvida uma das maiores vocações que teve o ensino médico brasileiro" (A. M. CASTRO, 2003, p. 17).

25 "Devo honestamente confessar que maior influência do que os professores, teve na minha formação o convívio com alguns colegas" (A. M. CASTRO, 2003, p. 17).

${ }^{26}$ Ainda sobre o convívio com o grande antropólogo brasileiro, comentou: "um certo dia ele nos fez uma revelação suprema de que sairia um estudo seu sobre Augusto dos Anjos e a Psicanálise, num dos suplementos dominicais de 'O Jornal'. Isto na província em 1925, meu caro me pareceu a glória. Fomos comovidos até o Plano Inclinado comprar o numero do ' $\mathrm{O}$ Jornal' desdobramos as páginas com unção e lá encontramos o artigo com o título e nome do autor. Não me contive. Veio-me à alma uma inveja doida de tanta glória. Fui também ao Freud - um Freud de terceira classe, já comentado em tradução e lancei um ensaio tremendo, meu
} 
Foto 01 - Josué de Castro (Conclusão do
Curso de Medicina) aos 24 anos.

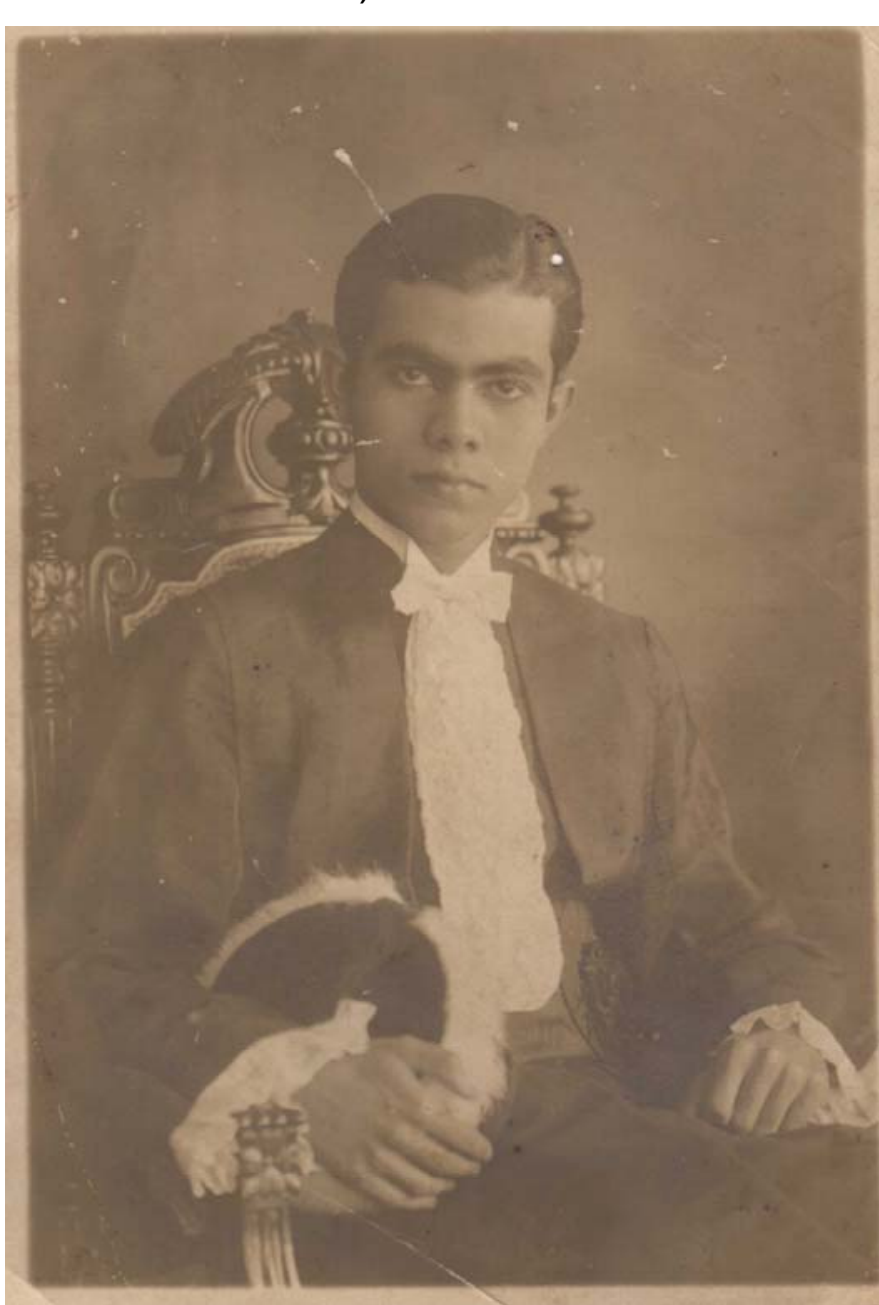

Fonte: Acervo do Centro Josué de Castro - Recife/PE

Depois de formado Josué regressa ao Recife e passa a atuar como médico fisiologista, e ainda numa grande fábrica da cidade a fim de verificar as condições de saúde do operariado ${ }^{27}$. Ancorado nessa experiência viria a

primeiro ensaio, intitulado 'A Literatura Moderna e a Doutrina de Freud' que saiu flamejante na Revista de Pernambuco. Senti-me como um igual e no ano seguinte passei a ir ao cinema junto com o mestre Arthur Ramos (A. M. CASTRO, 2003, p. 18).

${ }^{27}$ Sobre essa experiência comentara Josué que não conseguia diagnosticar nenhuma doença definida nos operários, mas curiosamente, eles não podiam trabalhar e, assim eram acusados de preguiçosos. Depois de algum tempo compreendeu o que se passava com eles e falou aos patrões: "sei o que meus clientes têm. Mas não posso curá-los porque sou médico e não diretor daqui. A doença dessa gente é fome. Pediram que eu me demitisse. Saí. Compreendi, então, que o problema era social. Não só do mocambo, não era só do Recife, nem só do Brasil, nem só do continente. Era um problema mundial, um drama universal" (A. M. CASTRO, 2003, p. $19)$. 
realizar um levantamento acerca das condições de vida das classes operárias do Recife por meio do Departamento Estadual de Saúde. Esse levantamento, ou inquérito é ressaltado unanimemente por todos aqueles que adentraram no universo castrino (MARCHI, 2004; NUNES, 2003; NASCIMENTO; 2002, SILVA, 1998; MAGALHAES, 1992) pelo seu pioneirismo. Com efeito, teve grande repercussão na época e serviu de inspiração para outros, posteriormente realizados no país e, que viriam a auxiliar o governo Vargas na implantação do salário mínimo ${ }^{28}$. Destaca o próprio Josué em Documentário do Nordeste, onde encontra-se o trabalho ${ }^{29}$,

Êste estudo foi levado a efeito em 1932 na cidade do Recife, sendo o primeiro inquérito realizado no Brasil sôbre as condições de vida do nosso povo. Abrindo a pista para êste gênero de pesquisa sociológica, logo surgiram inquéritos semelhantes noutras áreas do país, confirmando a trágica realidade social das massas brasileiras, que era até então como que ignorada, pelo menos dentro de uma visão objetiva dos fatos.

O inquérito consistiu na aplicação de questionários entre famílias de bairros e/ou localidades habitadas pelo proletariado a fim de verificar o percentual da renda mensal utilizado na aquisição de alimentos. Assim ele foi a campo e, de acordo com Montenegro (1983, p. 211), "dessa vez era o Governo que ele levava ao mangue". Constatou que $70 \%$ do que recebiam era para gastar com alimentos.

Paralelamente a estas atividades, Josué trabalhava na feitura da sua tese para concorrer ao cargo de livre-docente da cadeira de Fisiologia da Faculdade de Medicina, o que viria a ocorrer em 1932. A tese "O Problema Physiologico da Alimentação no Brasil”, além de elogiada, teve larga repercussão no meio intelectual e na imprensa local. Um jornal da época assim se referia ao concurso de Josué:

\footnotetext{
${ }^{28}$ Inicialmente publicado no Boletim do Ministério do Trabalho, Indústria e Comércio, em 1935 com título "O Valor da Alimentação", bem como no livro "Alimentação e Raça", também de 1935, porém intitulado "As Condições de Vida das Classes Operárias do Nordeste".

${ }^{29}$ Por solicitação do Ministro Agamenon Magalhães, orientou outros inquéritos no Ministério do Trabalho para colher dados necessários para mesma finalidade.
} 
$\mathrm{Si}$, na these escripta o dr. Josué de Castro mostrou-se profundo conhecedor da matéria, que expoz através de um estylo elegante, na defeza da mesma surprehendeu pelo vigor da argumentação pelos conhecimentos scientificos demonstrados. Isto é surprehendeu aos que ainda não conheciam a sua bella intelligencia, a sua dedicação ao estudo, reveladas desde os bancos academicos. $\mathrm{O}$ dr. Josue de Castro conquistou galhardamente a livre docencia da nossa Faculdade de Medicina. E ha de honrar o corpo docente desse superior instituto de ensino, pela fulguração do seu espirito" (FOLHA DA MANHA, s/d).

Dessa forma efetiva-se no cargo que vinha ocupando interinamente, contratado pela Congregação da Faculdade. No ano subseqüente, juntamente com um grupo de intelectuais pernambucanos, liderados por ele e o Professor Aníbal Bruno ${ }^{30}$ funda a Faculdade de Filosofia e Ciências Sociais do Recife. Inaugurada no dia 22 de setembro de 1933, em solenidade realizada no Salão Nobre da Faculdade de Direito do Recife, como atesta o anexo a seguir, esta Escola teve larga repercussão no meio intelectual da cidade, bem como do Estado, o que pode ser comprovado nas numerosas matérias publicadas em diferentes jornais da época. Ademais, constitui um marco na história do ensino superior em Pernambuco, seja pelo pioneirismo, seja pela proposta.

Até então, a despeito da sua posição como importante centro da intelectualidade brasileira, dispondo de Escolas tradicionais como as Faculdades de Direito, Medicina, das Escolas de Engenharia; Odontologia; Farmácia e Belas Artes, não dispunha de uma Faculdade de Filosofia. Só na década seguinte, mais precisamente em 1940, seria fundada a Faculdade de Filosofia do Recife (atual Faculdade Frassinetti do Recife) e, três anos mais tarde, a Faculdade de Filosofia, Ciências e Letras Manoel da Nóbrega (embrião da atual Universidade Católica de Pernambuco). E, mais adiante, por ocasião da fundação da Universidade Federal de Pernambuco em 1946, foi instituída a Faculdade de Filosofia de Pernambuco, que só iniciaria as suas atividades a partir de 1950.

\footnotetext{
${ }^{30}$ Médico, Jurista, professor livre-docente da Faculdade de Medicina do Recife e do Ginásio Pernambucano, membro da Academia Pernambucana de Letras, autor de vários livros nas áreas de saúde, direito e filologia, Aníbal Bruno foi um intelectual de grande prestígio em meados do século passado.
} 
Cópia do Jornal Diário da Tarde. Recife 22 de Setembro de 1933.

Assim, a escola vem preencher uma grande lacuna, que conforme Josué, em entrevista ao jornal O Estado, em 24 de setembro de 1933, há muito fazia 
sentir-se no nível cultural de Pernambuco. Na ocasião, quando questionado sobre a natureza teórica que a nova Faculdade poderia apresentar, dissera:

É bem verdade que há quem julgue inúteis essas escolas chamadas de teóricas, alegando nos faltarem técnicos e que o Brasil vive cheio de cientistas teóricos, absolutamente desnecessários. Mas é um engano, é preciso não confundir erudição com verdadeira cultura. Não nos faltam apenas técnicos, mas também elementos com cultura teórica bem formada. Esses nos são ainda mais indispensáveis, porque fazer as cousas é muito fácil - o difícil é fazê-las e compará-las com espírito rigorosamente científico. E esse espírito só se forma com uma larga cultura viva, com o conhecimento direto dos fenômenos naturais, do campo sociológico - pela investigação e comparação dos problemas sociais (O ESTADO, 24/09/1933).

$\mathrm{Na}$ verdade, inspirado no modelo europeu, ele via na criação da Faculdade de Filosofia o ponto de partida para criação de uma universidade, ainda inexistente no país naquele momento. Partia do entendimento que em grandes centros culturais, a exemplo da Rússia, Alemanha e Estados Unidos, as Universidades giravam em torno da Escola de Filosofia.

$\mathrm{Na}$ nova Faculdade, foi vice-diretor e professor de Antropogeografia Social, que na sua concepção consistia numa introdução geográfica à História e à Sociologia. Na elaboração do conteúdo programático da disciplina optou por dividi-la em três partes: (1) influências geográficas: a vida e o meio exterior; o homem e o meio físico. Geografia Humana, morfologia social: meio físico e organização social. Evolução humana e evolução histórica; (2) estudo dos meios naturais. Fatores telúricos e climáticos. O clima e a aclimação humana. Fatores fisiológicos e teoria da aclimação; (3) estudo das raças, dos povos, gêneros de vida. Hábitos e costumes, organização econômica, a cidade e o campo. Certamente esse foi o seu primeiro contato com a Geografia na condição de docente.

Quadro 07 - Fragmentos do Discurso Pronunciado por Josué de Castro na Solenidade de Inauguração da Faculdade de Filosofia e Ciências Sociais do Recife 
Excelentíssimo senhor interventor federal, Senhores professores, Meus senhores...

Os homens de boa vontade se congregaram para formar esta Faculdade de Filosofia são indubitavelmente uns grandes idealistas, possuidores dum complexo espiritual, onde predominam, contudo as qualidades manipuladoras sobre as sonhadoras. São idealistas, pelo desejo impessoal, desinteressado de criar, pela ânsia de renovar a nossa cultura, em busca do melhor, do mais perfeito. $\mathcal{N}$ ão têm felizmente o desvairio dos idealistas sonhadores que perdendo o senso da realidade, vivem numa exaltação flamejante a arquitetarem fantasias e aspirarem o impossível.

Esses que sabem sentir e sabem ver, também saberão desejar e poderão produzir. Os seus idealismos não serão simples refúgios contra as realidades esperadas da vida. Seus idealismos não serão covardias como assevera Spengler. Seus idealismos serão sempre desafios, serão muitas vezes lutas impetuosas, serão algumas vezes brilhantes vitórias. Vitória que desconcertam e aniquilam, os snobs profissionais, "os homens das comparações displicentes, sábios desalentados que conhecem todas as coisas e estão sempre em função de corrigir os nossos defeitos com as doutrinas de sua divertida ciência de maldizer".

Meus senhores, nós sabemos que temos de lutar com muitas dificuldades, sabemos que os resultados aparentes não serão deslumbradores, mas calculamos o seu alcance e acreditamos com fé que havemos de vencer, principalmente porque nós temos consciência que acima das causas transitórias e acidentais, acima das livres conveniências dos individuos que determinam os acontecimentos sociais há uma lei de importância superior que domina o conjunto.

$\mathcal{N a ̃ o}$ nos atemorizam as dificuldades materiais. Estudo, ciência e pobreza já aprenderam a andar juntos, não só no nosso país, mas em toda parte do mundo.

Para todos, nós, fundadores dessa Faculdade, e vós que trazeis a esta reunião o vosso apoio e a vossa simpatia espiritual, esse momento é de uma grande transcendência. Nãa encontro senão as seguintes palavras que possam exprimir com simplicidade e eficiência toda a sua densidade de perspectivas e de significação: no momento em que se instala entre nós uma Faculdade de Filosofia e Ciências Sociais, processa-se uma revolução cultural. Não foi sem razão, sr. Interventor, que convidamos o chefe civil de nossa revolução social para presidir esta sessão. As revoluções culturais são os germes de todas as idéias revolucionarias - no sentido mais nobre da palavra - de agitação e rebeldia espirituais coletivas em busca de renovação de valores e de novas condutas de expressão.

Também nos ensina a Filosofia da história que todas as revoluções sociais nos impõe não só, novos problemas de economia e de política, como também novos problemas de cultura. Com um fervoroso amor intelectual que lancei entre os meus colegas, chego a dar a criação desta Escola, a culminante significação dum fato histórico e segundo a concepção que esbocei no começo, busco a sua causa primária.

Em setembro de mil novecentos e trinta, num artigo sobre educação, eu escrevia, que os governos vanguardistas põem sempre no primeiro plano de sua administração os problemas de sua educação. Pesando o que se tem feito neste sentido depois da revolução, podemos asseverar que temos um governo de vanguarda. Os novos dirigentes não cometeram o erro muito comum entre os revolucionários anti-intelectualistas em extremo, que julgando a cultura um lastro inútil abandonam os problemas de estudo pelos de ação imediata. A revolução russa é um exemplo frisante desse lamentável erro. Os seus chefes julgaram a principio, prescindirem da ciência e da cultura, mas tiveram cedo de mudar essa orientação política, sentindo a necessidade urgente de formar homens espiritualmente capazes nos diferentes aspectos, sem a colaboração dos quais, não é possivel, nem a organização dum governo eficiente, nem o equilíbrio econômico dum pais. 
O plano de educação foi então erguido num novo sistema de base socialista, como um aparelhamento reprodutor de homens educados dentro de um espirito coletivista, identificados com a terra e os seus problemas. Outros exemplos nos foram proveitosos, porque caímos logo no caminho certo sem mais experimentos tateios. Os poderes públicos do novo regime têm cuidado com interesse dos problemas de educação.

Contudo, meus senhores, tão extensiva reforma não foi além de certos limites, dos limites do que se tem convencionado no Brasil em matéria de metodologia e organização de ensino. Tem sido muito limitado entre nós, o verdadeiro sentido de Vniversidade, e deturpado o senso preciso de ensino universitário.

Fonte: O Estado. Recife, 24 de setembro de 1933.

Não obstante o êxito logrado seja na Faculdade de Medicina, seja na Faculdade de Filosofia, e ainda a atividade médica, em 1935 Josué resolve voltar para o Rio de Janeiro e por intermédio do amigo Roquete Pinto ingressa na Universidade do Distrito Federal (UDF) como professor de Antropologia Física em 1936. Porém, a UDF teria vida curta e seria extinta com o advento do Estado Novo, passando a constituir a Faculdade Nacional de Filosofia da nascente Universidade do Brasil. Nesse processo a cadeira lecionada por Josué fora suprimida e em 1940, após uma breve passagem pela Itália ele passa a lecionar na FNF/UB. Através de um Decreto de 02 de julho de 1940, Josué assume interinamente a Cátedra de Geografia Humana até 1948, quando realiza-se o concurso e torna-se titular.

A partir desse momento aproxima-se e vincula-se mais diretamente aos projetos mais amplos do governo constituindo-se em um importante aliado de Vargas (MAGALHÃES, 1998, p. 47). Chefiou o Serviço Técnico de Alimentação Nacional $^{21}$, organizou e dirigiu o Serviço Central de Alimentação, que originou o Serviço de Alimentação da Previdência Social - SAPS; foi vice-diretor da Comissão Nacional de Bem-Estar Social e integrou a Comissão Nacional de Reforma Agrária. Foi também representante do país em importantes fóruns de

\footnotetext{
${ }^{21}$ Foi através deste órgão que Josué com um grupo de nutrólogos lançou a primeira publicação periódica sobre nutrição no Brasil: os Arquivos Brasileiros de Nutrição, que permitiu a divulgação dos avanços da ciência da nutrição no país e da qual foi supervisor científico por vários anos (Magalhães, Op. Cit: 46).
} 
debates e planejamento de políticas alimentares, integrou e dirigiu entidades e associações, e lecionou como catedrático a cadeira de nutrição do curso de sanitaristas do Departamento Nacional de Saúde. A carta do então ministro João Goulart recusando o seu pedido de exoneração da Comissão Nacional de Bem-Estar Social, deixar evidente a sua importância na área. Os resultados exitosos, concederam-lhe as prerrogativas de principal autoridade, seja do saber, seja da política de alimentação no país e reconhecimento internacional.

Dois eventos, contudo, marcaram excepcionalmente a trajetória de Josué de Castro nesse momento. O primeiro, foi a implantação do Instituto de Nutrição da Universidade do Brasil, do qual foi um dos idealizadores e se tornara diretor em 1946; o segundo, foi a sua atuação como Presidente do Conselho Executivo da FAO por dois mandatos consecutivos de 1952 a 1956.

À frente da FAO Josué persistiu na sua luta no combate a fome e a desnutrição. No entanto viu frustrados os planos de alargar e concretizar os seus ideais em função dos preceitos que norteavam as ações da entidade, dentre os quais aqueles que preconizavam que para "a humanidade alimentarse melhor seria suficiente, apenas, educar os agricultores e pescadores, fazendo-os seguir modernos métodos agrotécnicos” (Ritter, 1958: 26) ou, vê a questão alimentar como sendo estritamente um problema agrícola. Apesar das muitas tentativas não conseguiu sensibilizar os governantes dos países desenvolvidos para instituir uma reserva internacional contra a fome, ou mesmo, uma campanha mundial de combate a este mal.

Também se inicia na política dentro do PTB e ao longo desse período (entre os anos 30 e os anos 50 ) publica o que há de mais expressivo no conjunto da sua obra, desde "A Alimentação Brasileira à Luz da Geografia Humana", publicado em 1937, aos clássicos "Geografia da Fome" e "Geopolítica da Fome" em 1946 e 1951 respectivamente, onde delata as causas e efeitos de espectros como a miséria, o subdesenvolvimento, mas, sobretudo, a fome, a qual desmistificou e mostrou ao mundo como fenômeno criado pelo homem e que o tem acompanhado desde os tempos mais remotos. 
Correspondência do Ministro João Goulart para o Professor Josué de Castro. 
Correspondência do Ministro João Goulart para o Professor Josué de Castro. 


\section{PARTE}

FOME: DESCONTRUINDO UM CONCEITO E DECIFRANDO AS ESPECIFICIDADES SUBJACENTES

III Capítulo - Desvelando um Tema nas Entrelinhas da História 
Conforme enunciado no capítulo anterior, a fome tem acompanhado o homem desde os tempos mais remotos. Na verdade, a história da humanidade tem sido, desde o princípio, a história de sua luta pela obtenção do pão-nossode-cada-dia ${ }^{31}$. A guisa de exemplo, pode-se apontar uma das primeiras passagens do Livro do Gênesis:

Criou, pois, Deus o homem à sua imagem; à imagem de Deus o criou; homem e mulher os criou. Então Deus os abençoou e Ihes disse: Frutificai e multiplicaivos (...) Disse-lhes mais: Eis que vos tenho dado todas as ervas que produzem semente, as quais se acham sobre a face de toda a terra, bem como todas as árvores em que há fruto que dê semente; ser-vos-ão para mantimento. E a todos os animais da terra, a todas as aves do céu e a todo ser vivente que se arrasta sobre a terra, tenho dado todas as ervas verdes como mantimento. E assim foi (Gênesis 1 - 27, 28, 29, 30).

No mesmo livro é possível encontrar algumas das primeiras referências sobre o fenômeno da fome na história; inicialmente quando o Senhor ordena a Abrão que parta à terra de Canaã. "Ao migrar, levando consigo Sarai, sua mulher, e a Ló, filho de seu irmão, e todos os bens que haviam adquirido, e as almas que Ihes acresceram em Harã, à terra de Canaã chegaram. Passou Abrão pela terra até o lugar de Siquém (...) Depois continuou o seu caminho, seguindo ainda para o sul. Ora, havia fome naquela terra; Abrão, pois, desceu ao Egito, para peregrinar ali, porquanto era grande a fome na terra (Gênesis 12 $-1,5,6,9,10)$.

Mais adiante, ainda no mesmo livro, faz-se referência a uma das calamidades de fome mais conhecidas na história - a fome do Egito. Tal episódio está associado a figura de José, cananeu filho de Jacó com Raquel, vendido como escravo ao capitão da guarda do faraó, e que tornara-se notável pela habilidade de decifrar sonhos. Assim, ao decifrar um sonho do Faraó, revelou a grande forme que se abateria sobre o Egito. Disse José ao Faraó que as sete vacas gordas e as sete espigas boas com que sonhara seriam sete anos. Mais sete anos seriam as sete vacas magras e feias e as sete espigas

\footnotetext{
${ }^{31}$ Nesse sentido, Castro (1968b, p. 45) assegura ser difícil explicar e ainda mais difícil compreender o fato singular de que o homem - este animal pretensiosamente superior, que tantas batalhas venceu contra as forcas da natureza, que acabou por se proclamar seu mestre e senhor - não tenha até agora obtido uma vitória decisiva nesta luta por sua própria subsistência.
} 
miúdas e queimadas do vento oriental. Portanto, eis que estava por vir sete anos de grande fartura em toda a terra do Egito; a estes seguiriam sete anos de fome, e toda aquela fartura seria esquecida na terra do Egito e a fome consumiria a terra que não prosperaria por causa da grave fome que seguiria; (Gênesis $39-1 ; 41-26,27,29,30,31$ ).

Sugeriu então José ao Faraó que armazenasse um quinto da produção egípcia nos sete anos de fartura para provimento nos sete anos de fome a fim de que a terra não perecesse de fome. $(41 ; 34-36)$. E acontecera de passar-se os sete anos de fartura e começaram a vir os sete anos de fome, como dissera José. Logo a fome se abatia por toda a terra, mas no Egito havia pão. Entretanto, a fome aí também chegou, e José abriu todos os depósitos para vender aos egípcios e aos povos de outras terras que iam ao Egito para comprarem de José; já que a fome prevaleceu em todas as terras. (Gênesis 41 53 - 57) A fome era gravíssima na terra. (Gênesis 42-5; 43-1).

$\mathrm{Na}$ literatura antiga pode-se encontrar várias referências e relatos de epidemias de fome, quase sempre associadas a inclemências da natureza, o que era motivo para crendices e rituais a fim de agradá-la e assim obter o alimento. Nessa perspectiva, mostra Tuan (2005, p. 96) que "os antigos chineses, especialmente durante a dinastia Shang (c. 1550-1300 a.C.), acreditavam que os sacrifícios humanos eram necessários para promover a fertilidade da terra". A escassez de comida e a fome constituíam ameaças constantes não só aos chineses como também aos hindus. Conforme o mesmo autor,

$\mathrm{Na}$ Índia, uma das piores calamidades de todos os tempos ocorreu em 1770, como resultado de dois anos de colheitas magras seguidos pela completa falta de chuvas no terceiro ano. Cerca de 30 milhões de pessoas em Bengala Ocidental e em Bihar sofreram, e talvez perto de 10 milhões delas morreram de inanição e doenças. Em Orissa e ao longo da maior parte da costa oriental da Índia, a seca de 1865-1866, seguida de chuvas torrenciais em 1867 e a inábil política governamental, produziram cerca de 10 milhões de mortes por doenças e falta de alimentos. Na China, praticamente não choveu entre 1876 e 1879 nas densamente povoadas províncias setentrionais, a fome $e$ as conseqüências explosões de violência mataram entre 9 e 13 milhões de pessoas. Fomes produzidas pela seca ocorreram novamente nos anos de 1892-1894, 1900, 1920-1921 e 1928: o numero de pessoas que morreram durante e logo após cada um dos desastres variou entre 500 mil e três milhões (TUAN, 2005, p. 99/100). 
Infelizmente nem sempre os documentos históricos descrevem os fatos decorrentes da fome em toda a sua desolação e horror. Sugere Tuan (Op. Cit., p. 101) que 'as autoridades que testemunharam os desastres escreveram em um estilo formal e parece que omitiram seus sentimentos', talvez porque eles próprios tinham o suficiente para comer quando procuravam ajudar aos moribundos que se amontoavam ao redor deles ${ }^{32}$. Os famintos, quando sobreviviam, não tinham condições para registrar a profundidade da sua angústia. Assim, o problema não é tratado na sua totalidade, o que impede um conhecimento mais profundo e, por conseguinte, uma análise condizente com a realidade de fato. Depois, é importante salientar, muito se perde em termos de conhecimento e possibilidades de pensar o presente e projetar o futuro.

Mas as calamidades, as epidemias de fome não são uma exclusividade do mundo oriental, mas estão em toda parte. Foram uma constante na Europa até os tempos modernos. Fomes de comparável severidade foram ameaças habituais para as cidades européias no final da Idade Média. Conforme Tuan (Op. Cit., p. 106) "nos arquivos de Toulouse podem se localizar sete períodos de fome entre 1334 e meados do século XVII". O problema com o abastecimento de alimentos se tornou, em todas as partes, um problema constante, agudamente sentido em todas as comunidades municipais - na Itália, assim como também na Alemanha. Na França do século XVII, insuficiência de alimentos, fomes e períodos de relativo bem-estar revezavamse com perversa regularidade. Tempo ruim e colheitas magras causaram a fome geral de 1661-1662. Mendigos das áreas rurais aglomeravam-se nos portões das cidades e de instituições de caridade, pedindo pão ${ }^{33}$. A Inglaterra

\footnotetext{
${ }^{32}$ Sobre esse aspecto, observa Tuan (Op. Cit., p. 104): "Os governos tinham o poder e a organização para arrecadar impostos e recrutar homens para a guerra contra os inimigos humanos. Por que não puderam lutar contra a natureza e pelo menos para mitigar a aflição do povo? Alguns governantes não tinham disposição; de fato o relato de Kalhana sobre a fome na Caxemira (917-918 e 1099-1100) sugere que os reis e ministros abertamente procuravam tirar proveito pessoal dos desastres naturais".

${ }^{33}$ Em abril de 1693, um funcionário subalterno da diocese de Beauvais observou: um número infinito de infelizes almas, débeis pela fome e desgraça e morrendo de miséria e falta de pão nas ruas e praças, nas cidades e no campo, porque não tendo trabalho ou ocupação carecem de dinheiro para comprar pão. Procurando prolongar um pouco suas vidas, estes pobres homens comem coisas impuras, como gatos e carne de cavalos esfolados e jogados em
} 
dos Tudor e Stuart, igualmente não escapou da fome. Pessoas morriam por falta de alimento no norte da Inglaterra em 1587-1588, 1597 e 1623.

Mesmo não trazendo à luz o drama histórico da fome em todo o mundo, não é difícil concebê-lo como um drama mundial a perseguir a humanidade e que tem uma dimensão espaço-temporal. Depois, como bem diz Minayo (1995, p. 21) "a fome é um fenômeno histórico que povos e nações conseguiram erradicar e que outros povos e nações vêem-na aprofundar-se como um mal que se alastra e assola a sua gente, torna-a frágil e dependente". Se ela é um problema milenar não se quer considerá-la ao mesmo tempo do ponto de vista fatalista, insolúvel e eterno, como determina o imperialismo econômico dos países centrais obcecados pela ambição do lucro e interessados numa produção, distribuição dos alimentos como um fator puramente econômico, e dirigidos no sentido de seus exclusivos interesses financeiros em detrimento de sua função social. Segundo Castro (1968b, p. 49)

A civilização européia contemporânea, que alcançou seu apogeu com a expansão do horizonte geográfico do mundo, depois do século XVII, e pela economia colonial que se Ihe seguiu, não convinha de modo algum divulgar, no seu meio de aparente esplendor, a feia tragédia da fome, produto, em grande parte, desse colonialismo desumanizado. Produto, antes de tudo da desumana exploração das riquezas coloniais por processos de economia devastadores, monocultura e latifúndio, que permitiam a obtenção, por preços vis, das matérias-primas indispensáveis ao seu industrialismo próspero.

Percebe-se dessa forma, que foram, sobretudo, os interesses de ordem econômica que omitiram do mundo tragédias como as ocorridas na Ásia ou na Europa, acima mencionadas. E nesse sentido, a literatura ocidental indissoluvelmente ligada ao patrimônio mental desta mesma cultura, servindo aos seus interesses e deslumbrada pelo seu falso esplendor, fez-se, pois, cúmplice do silêncio ${ }^{34}$, que ocultou aos olhos do mundo a verdadeira situação

montes de excrementos... Outros desenterravam os feijões e sementes de milho plantados na primavera (TUAN, 2005, p. 108).

${ }^{34}$ Para Castro (1968b, p. 50), Poucos foram os escritores corajosos que se aventuraram a violar o tabu e trazer à luz da publicidade as negruras desse mundo subterrâneo da fome e da miséria: um Knut Hamsun, no seu magistral romance Fome - verdadeiro relato minucioso e exato das diferentes, contraditórias e confusas sensações que a fome produzia no autor; um Panaït Istrati, vagando esfomeado pelas luminosas planícies da Romênia, um Felekov e um Alexandre Neverov, narrando com dramática intensidade a fome negra na Rússia em convulsão social; um George Fink sofrendo fome nos subúrbios cinzentos e sórdidos de Berlim, um João Steinbeck, contando, em Vinhas da Ira, a epopéia de fome da família Joad, através 
de enormes massas humanas debatendo-se dentro do círculo de ferro da fome. (CASTRO, 1968b, p. 49). Silêncio que fazia-se sentir não apenas na literatura em seu sentido mais amplo, mas especialmente na literatura acadêmica encastelada pelo positivismo que a impedia de trilhar por uma perspectiva social mais crítica, centrada na verdadeira realidade e que fosse capaz de desmistificá-la. Nesse contexto inseria-se a Geografia, que influenciada pelo possibilismo vidalino, bem como pelas teses ratzelianas, eludia-se da esfera social, optando por uma análise mais naturalista, como se verá na seqüência.

IV Capítulo - Revisitando os Pressupostos da Fome como uma Categoria de Análise na Geografia

das mais ricas regiões do mundo - os Estados Unidos da América. Mas esses e alguns poucos mais constituíram simples vozes perdidas num deserto de indiferença. 
Na Geografia Clássica a alimentação aparece como tema de destaque, e por assim ser, com freqüência vai compor um capítulo ou subcapítulo de uma considerável parte das obras publicadas na primeira metade do século passado. Especialmente aquelas de autores franceses ou então vinculados a Escola Francesa, em face a importância por essa dispensada ao estudo dos gêneros de vida ${ }^{35}$. No dizer de La Bhache (1954, p 195) "entre as relações que ligam o homem a um certo meio, uma das mais tenazes é a que aparece quando se estudam os modos de alimentação". E, complementa,

O vestuário e o armamento são muito mais sujeitos a modificações sob a influência do comércio, do que o regime alimentar, por meio do qual, empiricamente, os diferentes grupos recorrem as necessidades do organismo conforme os climas em que vivem (LA BHACHE, 1954, p 195).

Entretanto, conforme afirmado, essa importância estava vinculada aos gêneros de vida e não passará de uma descrição a propósito do sistema alimentar das diversas áreas do planeta. Consistindo, pois, num estudo geográfico da alimentação, igualmente ao que se fazia com a etnia, com as línguas, com a religião etc. Contudo, aponta Max Sorre (1958, p. 224) que a Geografia da Alimentação consiste no capítulo inicial de toda a Geografia Humana. E tem como objetivo averiguar em que medida e quais os meios os grupos humanos atendem ao crescimento do organismo e the proporcionam materiais energéticos, conforme o mestre francês no segundo capítulo (Consistência do Ecúmeno) do seu clássico "El Hombre en la Tierra" (SORRE, 1967, p. 32).

É importante observar que não se fala em fome, mas em alimentação ou subalimentação. E tal questão não é uma exclusividade do pensamento sorriano ou vidalino. Aliás, na síntese da sua trilogia, acima citada, Sorre (1967, p. 32) já utiliza a expressão ancorado em Josué de Castro, ao afirmar que

A importância de muitos regimes por satisfazer as necessidades dos grupos humanos faz que concentremos nossa atenção em um ultimo problema: a fome. Seguindo o exemplo de Josué de Castro, que tem escrito sobre a geografia da fome, situemos ao lado das fomes, as carestias e os déficits

\footnotetext{
${ }^{35}$ Para Max Sorre (1967, p. 32) "O regime alimentar expressa a totalidade dos traços de gênero de vida. Não só as técnicas tradicionais, pastoris, agrícolas e industriais, senão também os traços imaterias, prescrições e proibições derivadas das crenças".
} 
alimentares. Se é que se pode falar assim, junto a fome absoluta, a fome de tal o qual elemento ausente de regime ou pouco representado nele.

Até o advento da obra seminal de Josué de Castro, "Geografia da Fome", em 1946, assim era. E isso pode ser comprovado na obra do próprio Josué, que em 1937 publica "A Alimentação Brasileira à Luz da Geografia Humana", um importante livro sobre a questão alimentar, onde o autor não chega a falar em fome. Contudo, deve-se aludir a importância desse livro, onde a Geografia pela primeira vez toma lugar central no conjunto da sua obra, e por constituir uma espécie de prévia daquele que seria o seu trabalho mais divulgado (Geografia da Fome). A despeito do que se dera no meio geográfico, que não despertou maior interesse, tivera o livro uma aceitação considerável fora dela, sendo inclusive agraciado com o prêmio da Casa dos Amigos de Alberto Torres. Foi amplamente comentado e elogiado pela imprensa e pela classe intelectual. O texto de Afrânio Peixoto ${ }^{36}$, no quadro a seguir (02) serve para justificar essa afirmação.

Quadro 08 - A Alimentação Brasileira à Luz da Geografia Humana por Afrânio Peixoto.

"A alimentação Grasileira à luz da geographia humana"

Afrânio PEIXOTO

(Prof. de Hygiene na Universidade do Rio de Janeiro)

(Especial para O JORJAL)

O Autor deste livro já dispensaria uma apresentação. O exito do seu "O Problema da Alimentação no Brasil", que teve a honra de um prefácio do professor Pedro Escudero, de Buenos Aires, já o classificou entre os modernos nutricionistas dos paiz. Este volume, em que me confere a honra destas palavras. - "A Alimentação Grasileira à luz da Geographia Humana" - reitera-The os créditos, e confirma as esperanças que nos trouxe nesta seara nova da physiologia, da hygiene, da sociologia. É um pioneiro da nutrologia no Brasil: seus dois livros são os marcos de partida de uma estrada longa a percorrer, mas na qual suas idéias correrão triumphalmente.

Desde que se demonstrou que há uma anthropologia de ricos e pobres, isto é, de supernutridos e desnutridos, podendo, Binet, Burgraeve, Niceforo, Mae Donald, Schuyten... denunciar o pauperrismo somaticamente, pois meninos pobres de 14 anos tinham, 1m.46, emquanto ricos, da mesma idade, mediam 1m.50; homens pobres orçam por $1 \mathrm{~m} .54 \mathrm{em}$ média, emquanto ricos têm $1 \mathrm{~m} .68$... que as consciências do mundo entraram numa apprenhensão que não é só scientifica, senão

\footnotetext{
${ }^{36}$ Importante intelectual brasileiro da primeira metade do século passado, nascido na Bahia (Lençóis), Afrânio Peixoto foi médico de formação, título que obteve na Faculdade de Medicina da Bahia, ao longo da vida foi crítico, ensaísta, político e professor. Foi reitor da Universidade do Distrito Federal e membro da Academia Brasileira de Letras.
} 
politica e, mais ainda, moral.

Como ha uma anthropologia, ha uma physiologia de classe: Isserlis e Wood, na Inglaterra, Hartnake e Wood, nos Estados Unidos, Hetzer e Wolf, na Áustria, Décroly, na Bélgica, Descoeudres, na Suissa... etc... demonstraram que o quociente actual médio das crianças da classe operaria é um quarto, ou um terço, mais baixo que o do das crianças da classe abastada.

Quem diz anthropologia e physiologia diz tudo, porque vida e perfeição ou moralidade, da vida são decorrências. A conclusão, sem esforço, de quem não tem medo da verdade, é que a crise política e moral do mundo é uma doença de nutrição. Super-nutridos, violentos e atemorizados: su6-nutridos, irritáveis e pervertidos... Em vez de policia, revoluções, anathemas, que não curam nada, hygiene, que previne tudo...

O conhecimento é isso que vem trazer a nutrologia. O metabolismo e seus arcanos, a nutrição e sua necessidade. Tudo está ahi, até a "populacidade". Já os romanos juntavam, na mesma palavra, "proletário", o que vive de magro salário, e por isso tem prole numerosa. Não é só inconsciência em produzil-a. Quando o individuo é precario, a espécie domina-o. A arvore muito adubada ou podada - trato do individuo - enfolha, copa, avulta, mas não frutifica. $\mathcal{N a}$ segurança e abastança dos jardins zoológicos os animais não procreari, engordam. $\mathcal{N a}$ épocas de crise, chômage, guerra, epidemia, em que os indivíduos sofrem, a espécie se derrama... Como que a natureza toma precauções, pressentindo o perigo individual. As sociedades fartas são escassas de gente: produzem pouco, produzem bellos e bons typos. $\mathcal{N a}$ ante-guerra, tanto a França como a Alemanha, os Estados Unidos já estacionavam, senão cresciam apenas como imigração: com o sofrimento $e$ penúria. Alemanha de agora, Itália, China, Japão, trans6ordam. Portanto, alimentação ou nutrição será a chave da sociologia, da política da moral. Será a da saúde physica e mental da humanidade. Será a da felicidade ou do sofrimento. É escolher.

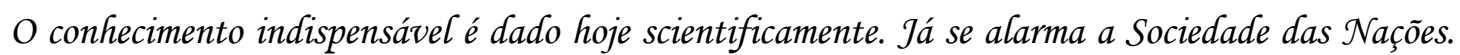
Dos seus inquéritos se verifica a doença do mundo: sub-nutrição.

Ah! se os ingleses não fossem agora tão mal nutridos!... diz um estadista, olhando para o Mediterrâneo... Roosevelt gastou 50 bifhões de dólares em quatro anos - a maior soma que o mundo já somou - para impedir que 12 milhões de homens desempregados entrassem em fome desespero, revolução... Palácios denuncia a sub-nutrição argentina... Que diremos nós, povo em perpétua dieta? Se não fôra o clima, que ajuda a nossa miséria, já teríamos feito vários desesperos, ainda mais revoluções, que sei?!

Mas não fazemos nada de bom, porque estamos em dieta... Não comemos à nossa fome e muito menos a nossa possibilidade de fazer alguma coisa... E nos consolamos, com ironia, sem os contar, mas certamente exactos, com 48 milhões de brasileiros... pois que, sofrendo tanto os individuos, o povo aumenta e acabará por superlotar os nossos infinitos territórios... (não atentamos que, aumentando a gente, pelo que ela faz, diminue-se o paiz...).

Que fazer desses sub-homens? A sub-nação que somos. Tamanho paiz produz menos que as ithas modestas de Cuba ou de Java. Tanta gente produz menos que a quarta parte, dos argentinos, que fazem a Argentina... Terra e gente. Não basta.

O que é necessário é ser gente. Para isso é preciso, primeiro, nutrir-se. É o principio. Tudo o mais é consectário. O nosso pobre trabalhador rural ou urbano, quase não trabalha duas ou três horas em oito porque não pode. Chamamol-o preguiçoso. A um sueco repleto chamaríamos operoso... Taes adjectivos são calorias de mais ou de menos como a marcha dos aviões ou transatlânticos não são as cores, os tamanhos, as aparências, os pilotos, as nacionalidades, mas, apenas, as calorias servidas ao motor pelo combustível, para o trabalho mecânico... 
O trabalho humano também. As nossas empresas estrangeiras preferem dar comida ao operário brasileiro a pagal-o "a secco", porque comendo realmente o que deve e quando deve, tem oito horas certas de actividade. Não se pode exigir isto, de jejuadores...

o livro, os livros, do dr. Josué de Castro instalam a questão pelo seu lado objectivo e technico, deante de nós, dando-nos os elementos actuaes de julgamento. Se ainda não temos os Benedict, os Lefevre, os Saik, os Botazzi, os Escudero, já os nosso Osório, Annes Dias, Paula Souza, Josué de Castro iniciam, pela doutrinação, pela propaganda, com as noções básicas de metabolismo, climatologia, nutrologia, uma nova era que dará solução scientifica à maioria de nossos problemas de toda ordem. O povo de jejuadores que somos comerá mais ou tanto quanto a sua fome, as suas necessidades e não será mais de sub-homens que somam a su6-nação que vemos... Portanto, livro o grande, não só de hygiene, mas de civismo brasileiro, de idealismo humano.

Se me falta autoridade pessoal, tenho a do posto que occupo, e que me obriga, a reflectir no que digo, mais ainda quando o escrevo: este é um dos mais bellos livros que se escreveram, de hygiene, no Brasil.

Fonte: O JORNAL. Rio de Janeiro, 16 de Janeiro de 1937.

Depois de dois livros de fôlego - "O Problema da Alimentação no Brasil" e "Alimentação e Raça" - centrados na questão nutricional numa perspectiva mais técnica, em "A Alimentação Brasileira à Luz da Geografia Humana", Josué sem abandonar os rumos trilhados anteriormente, passa a discutir a questão contemplando o fator social de forma mais clara e objetiva, buscando aporte na ciência geográfica. Ainda que evidencie que o mesmo não se trata de uma monografia geográfica, não obstante a afirmação de que fora orientado sob a inspiração do espírito geográfico, com base em três dos cinco princípios geográficos (mostrados a seguir), tão comum e utilizados pelos geógrafos da época. Destarte, logo no inicio do livro esclarece:

Procuraremos estudar a questão alimentar no nosso meio, com as características que the impõem as varias condições externas, localizando as suas variantes em suas respectivas áreas de produção, até os seus limites naturais, o que está de acordo com o principio geográfico da extensão, enunciado por Frederich Ratzel - de que se deve sempre determinar a extensão dos fenômenos na superfície da terra (CASTRO, 1937, p. 26).

Na marcha desse estudo, não nos limitaremos à análise dos fenômenos do nosso meio, buscando interpretações imediatas. Visaremos, ao contrario, um estudo comparativo pelo cotejo com as manifestações análogas de expressão do fenômeno, noutras partes do globo, indo, assim, em busca de sua lei geral, de acordo com o sábio princípio da coordenação geográfica, expresso por Karl Ritter e recentemente apreendido com talento por Vidal de La Blache, quando afirmou "que nenhuma parte da terra leva em si a sua explicação (CASTRO, 1937, p. 26). 
O terceiro princípio geográfico, a que obedece nossa conduta de análise do problema, é o princípio da causalidade, que busca, no exame dum fenômeno, alcançar as causas que determinam sua extensão e intensidade. Foi Humboldt que pôs em relevo este princípio, o qual transformou a geografia de descritiva em explicativa. De açodo com este sentido doutrinário, buscaremos determinar as causas que condicionam a nossa alimentação, causas climáticas, botânicas, de organização agrícola e social, de nível de cultura etc., determinando até onde vai a influência de cada uma delas (CASTRO, 1937, p. 26/7).

\section{Quadro 09 - Princípios Geográficos}

\begin{tabular}{l|l|c}
\hline \hline PRINCÍPIO & \multicolumn{1}{c|}{ ENUNCIADO } & FORMULADOR \\
\hline \hline Extensão & $\begin{array}{l}\text { O geógrafo, ao estudar os fatores geográficos ou uma } \\
\text { área, inicialmente deve buscar localizá-la e estabelecer } \\
\text { os seus limites, usando os mapas disponíveis e o } \\
\text { conhecimento direto da área. }\end{array}$ & Friedric Ratzel \\
\hline Analogia & $\begin{array}{l}\text { Delimitada e observada uma área em estudo, não se } \\
\text { deve prescindir de compara-la com o que se observa em } \\
\text { outras áreas, estabelecendo as semelhanças e as } \\
\text { diferenças existentes. }\end{array}$ & Karl Ritter \\
\hline Causalidade & $\begin{array}{l}\text { Observado os fatos, se deverá procurar as causas que os } \\
\text { determinaram, estabelecendo relações de causa e efeito. }\end{array}$ & $\begin{array}{c}\text { Alexander von } \\
\text { Humboldt }\end{array}$ \\
\hline Conexidade & $\begin{array}{l}\text { Os fatores físicos e humanos, ao elaborarem as } \\
\text { paisagens, não agiram separada e independentemente, } \\
\text { havendo uma interpretação na ação dos vários fatores } \\
\text { físicos entre si, bem como de ambos. No decorrer do } \\
\text { processo, quaisquer fatores físicos ou humanos age de } \\
\text { forma isolada, mas sempre se dá de forma integrada com } \\
\text { outros fatores. }\end{array}$ & Jean Brunhes \\
\hline Atividade & $\begin{array}{l}\text { Refere-se ao dinamismo do fato geográfico, visto que o } \\
\text { espaço geográfico está em contínua mudança, em face a } \\
\text { constante ação dos vários fatores. }\end{array}$ & Jean Brunhes \\
\hline \hline
\end{tabular}

Organização: Antônio Alfredo Teles de Carvalho

Respaldado nesses princípios, o autor faz uma análise destacando a significativa importância da alimentação como fator econômico e social, ao mesmo tempo em que procura estabelecer um diálogo com La Blache que no seu entender orientou a Geografia Humana num sentido de melhor análise e 
maior prudência, ao encarar as influências mútuas entre o homem e o meio ${ }^{37}$. Criando assim, a noção de relações ativas, em lugar das influências deterministas do meio sobre o homem (...) Daí em diante, o estudo da ação do meio saiu do terreno das hipóteses obscuras para o campo claro das conexões, as inter-relações, conceitos hodiernos da moderna geografia, que deixou de ser a simples descrição da terra para ser a ciência da terra (CASTRO, 1937, p. 112).

Ao tratar do estudo de caso - a alimentação brasileira, com base em dados sociológicos, históricos e relatos de viajantes que atentaram sobre este aspecto, ressalta Castro que desde os primeiros tempos de colonização, sempre mostrou-se defeituosa e incompleta. Buscando decifrar o quadro da sua época, propõe um zoneamento do país, dividindo-o em regiões, correspondendo cada uma delas a um tipo de alimentação usual e característico. Nessa perspectiva, procura estabelecer os diversos tipos de alimentação brasileira, tendo em vista as substâncias alimentares básicas e as proporções mútuas em que elas são consumidas, chegando dessa forma a conclusão que a multiplicidade de regimes individuais se reduz esquematicamente a cinco tipos especiais, bem definidos, que são por ele mapeados (mapa 1), seguidos da proposta de cinco tipos de ração racional, apresentados na tabela seguinte.

\footnotetext{
${ }^{37}$ Ao longo do texto fica evidente a sua opção pelo possibilismo. Entretanto, chega a conclusão que o homem não escapa inteiramente a ação do meio; primeiro, porque procurando escapar tecnicamente a esta ação, ele está agindo em função dela, e, se a vence, não quer isto dizer que não a sofreu; segundo, porque, escapando a partir dum certo momento a sua ação direta, continua a sofrer indiretamente os seus efeitos, através da forma de alimentação que the vai fornecer os materiais nutritivos - que oportuna e lógica não nos parece, em seguida a esta exposição, a frase de Vidal de La Blache, acerca da forca tenaz que representa a alimentação, ligando o homem ao seu meio natural.
} 


\section{Mapa 1 - Zonas Alimentares do Brasil}

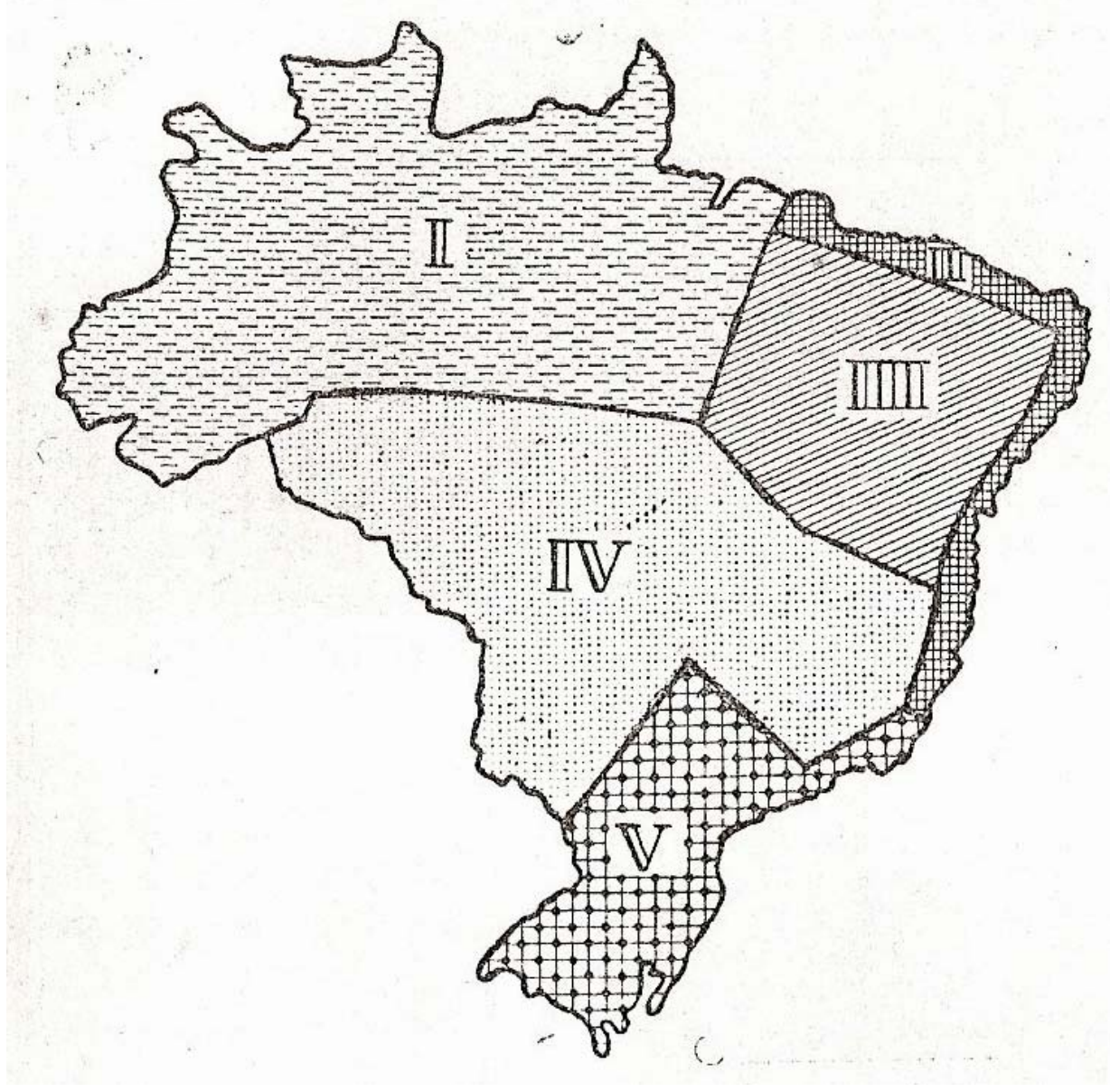

Fonte: CASTRO, Josué de. A Alimentação Brasileira à Luz da Geografia Humana. Porto Alegre: Livraria do Globo, 1937.

Quadro 10 - Zoneamento do Brasil em Função dos Tipos Regionais de Alimentação 


\begin{tabular}{|c|c|c|c|}
\hline ZONAS & Região Geográfica que Abrange & Alimentos Básicos & $\begin{array}{l}\text { Proporções } \\
\text { Mútuas }\end{array}$ \\
\hline $\begin{array}{l}\text { I } \\
\text { Zona Norte }\end{array}$ & Amazonas, Acre e Pará & $\begin{array}{l}\text { Farinha de Mandioca, } \\
\text { Feijão, } \\
\text { Peixe, } \\
\text { Castanha do Pará }\end{array}$ & $\begin{array}{l}3 \\
2 \\
1 \\
1\end{array}$ \\
\hline $\begin{array}{l}\text { II } \\
\text { Zona da Mata } \\
\text { do Nordeste }\end{array}$ & $\begin{array}{l}\text { A Faixa da mata dos Estados o Maranhão, Piauí, Ceará, } \\
\text { Rio Grande do Norte, Paraíba, Pernambuco, Alagoas, } \\
\text { Sergipe e Bahia. }\end{array}$ & $\begin{array}{l}\text { Farinha de Mandioca, } \\
\text { Feijão, } \\
\text { Aipim, } \\
\text { Charque. }\end{array}$ & $\begin{array}{l}3 \\
2 \\
2 \\
1\end{array}$ \\
\hline $\begin{array}{l}\text { III } \\
\text { Zona do Sertão } \\
\text { do Nordeste }\end{array}$ & $\begin{array}{l}\text { Sertão de Maranhão, Piauí, Ceará, Rio Grande do Norte, } \\
\text { Paraíba, Pernambuco, Alagoas, Sergipe, Bahia e norte de } \\
\text { Goiaz. }\end{array}$ & $\begin{array}{l}\text { Milho, } \\
\text { Feijão, } \\
\text { Carne, } \\
\text { Rapadura. }\end{array}$ & $\begin{array}{l}3 \\
1 \\
1 \\
1\end{array}$ \\
\hline $\begin{array}{c}\text { IV } \\
\text { Zona do Centro }\end{array}$ & Minas Gerais, Mato Grosso e Goiaz. & $\begin{array}{l}\text { Carne, } \\
\text { Feijão, } \\
\text { Milho, } \\
\text { Toucinho. }\end{array}$ & $\begin{array}{l}2 \\
2 \\
2 \\
1 \\
\end{array}$ \\
\hline $\begin{array}{c}\text { V } \\
\text { Zona do Sul }\end{array}$ & $\begin{array}{l}\text { São Paulo, Espírito Santo, Distrito Federal, Estado do Rio, } \\
\text { Paraná, Santa-Catarina, Rio Grande do Sul. }\end{array}$ & $\begin{array}{l}\text { Carne, } \\
\text { Pão, } \\
\text { Arroz, } \\
\text { Batata. }\end{array}$ & $\begin{array}{l}3 \\
3 \\
2 \\
1\end{array}$ \\
\hline
\end{tabular}

Fonte: CASTRO, Josué de. A Alimentação Brasileira à Luz da Geografia Humana. Porto Alegre: Livraria do Globo, 1937. p. 150 (Reproduzido conforme o original).

De acordo com o autor "todos os cinco regimes mantêm as proporções de alimentos orgânicos que julgamos convenientes na nossa exposição doutrinária e em total calórico, capaz e cobrir as despesas energéticas normais do organismo" (CASTRO, 1937, p. 159).

Por fim, faz-se mister reafirmar que mesmo não utilizando a expressão 'fome', esse livro assume relevância por inovar no estudo da alimentação, fazendo uso do conhecimento geográfico, utilizando os seus princípios, mapeando e, especialmente, por acenar o surgimento da fome como uma categoria passível de análise na Geografia. 
III PARTE

JOSUÉ DE CASTRO E A INCLUSÃO DA FOME NOS ESTUDOS GEOGRÁFICOS NO BRASIL 


\section{Capítulo - Josué de Castro e a Geografia: Recuperando um Percurso}

O percurso trilhado por Josué de Castro na Geografia, confunde-se com o seu processo de institucionalização e consolidação no Brasil. Conforme mostrado no segundo capítulo, em 1933, um ano antes da instalação do primeiro curso de Geografia no país, o autor já lecionava a disciplina na recém criada Faculdade de Filosofia e Ciências Sociais do Recife.

O regresso ao Rio de Janeiro dois anos depois, o deixaria temporariamente afastado da Geografia em sala de aula, mesmo tendo ingressado na Universidade do Distrito Federal (onde torna-se professor de Antropologia). Somente em 1940 acontece o seu retorno, quando passa a lecionar Geografia Humana na Faculdade Nacional de Filosofia da Universidade do Brasil na condição de catedrático interino. Através do concurso público realizado em março de 1948, se efetiva no cargo. Diante de uma banca examinadora presidida por Delgado de Carvalho e composta por Arthur Ramos, Alberto Lamego, Pedro Calmon e Christovam Leite de Castro, (conforme atesta o documento a seguir, onde contém o ponto sorteado para a prova didática) defendeu a tese "Fatores de Localização da Cidade do Recife". Segundo matéria publicada pelo jornal O Globo (quadro 03), defesa tranqüila em relação as ultimas realizadas.

No decorrer do período que precede o seu ingresso na Faculdade Nacional de Filosofia, Josué parece aproximar-se mais da Geografia. Reparese que afora "A Alimentação Brasileira à Luz da Geografia Humana", Josué lança em 1939, "Geografia Humana: Estudo da Paisagem Cultural do Mundo"38, pela mesma editora (Globo, de Porto Alegre). Trata-se de um livro

\footnotetext{
${ }^{38}$ Segundo o Professor Aziz Nacib Ab'Sáber apud Silva (1998, p. 230) "foi um livro que trouxe inovações, mas como um livro didático sempre existe uma diferença entre a característica de redação de uma obra científica original, eles são um esforço de sistematização a base de um conhecimento acumulado e, nesse sentido, o livro didático do Professor Josué não foi recebido com o mesmo entusiasmo que foram os seus livros sobre a fome. O livro era bom mas era uma síntese, com muitas informações de segunda origem (...) Então por esse motivo, por ser um livro didático que utilizava informações secundárias, embora de excelente nível, o livro não
} 
didático voltado ao ensino secundário, dentro do modelo então adotado pelos autores que seguiam a linha vidalina.

Nesse momento a influência da Escola Francesa já se mostra mais sistematizada, o que é perceptível na familiaridade demonstrada com autores como Emmanuel De Martone, Jean Brunhes, Max Sorre, Pierre Deffontaines e Lucien Febvre em muitos dos seus trabalhos. À guisa de exemplo ancora-se em De Martone, para espacializar o fenômeno a partir do conceito de geografia como ciência dos fenômenos físicos, biológicos e sociais distribuídos na superfície terrestre, suas causas e relações recíprocas, em Brunhes aprofunda a análise acerca dos gêneros de vida, ou mesmo Reclus, para falar em fome universal a partir de "Nouvelle Géographie Universelle".

chegou a mostrar uma originalidade tão grande quanto aquela que aconteceu com os livros Geografia da Fome e Geopolítica da Fome". 


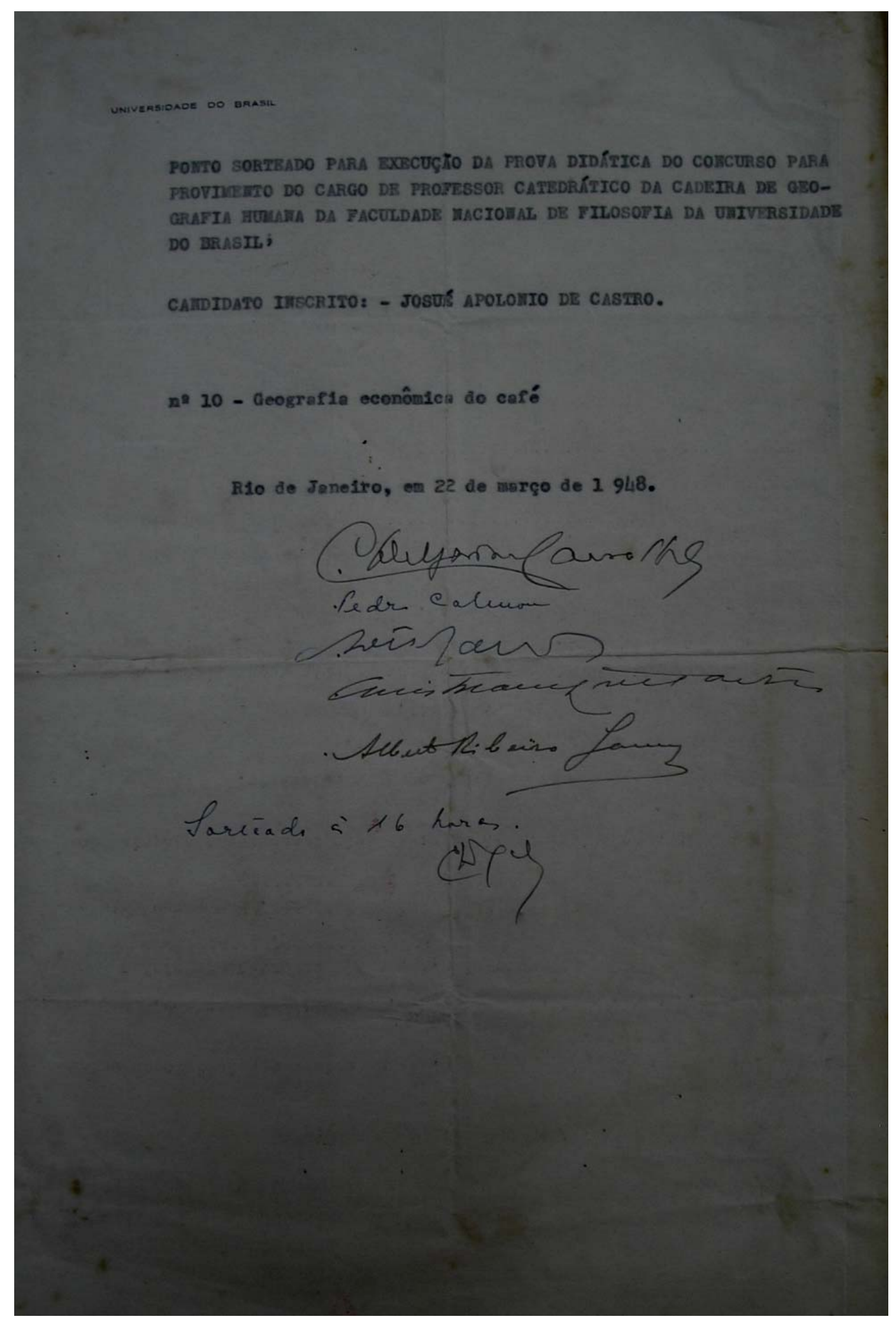

Fonte: Acervo do Centro Josué de Castro. Recife - 2006. 


\section{Quadro 11 - Concurso para a Cátedra de Geografia Humana da Faculdade Nacional de Filosofia da Universidade do Brasil}

\section{Mesa Redonda de Geografia Humana}

O Concurso para provimento efetivo da cátedra de Geografia Humana da Vniversidade do Brasil, a que se submeteu o professor de Geografia Josué de Castro com a sua tese: Fatores de Localização da Cidade do Recife, serviu, entre outras coisas igualmente preciosas, como oportunidade de revelações públicas das variadas posições assumidas pelos nossos em face da Geografia Humana. O candidato teve diante de si uma banca eclética, o que equivale dizer que de dentro do bojo das ciências do homem da terra e da sociedade surgiram "fronts" diferentes, de uma combatividade disciplinar e persistente, chamando-o com insistência aqueles campos de luta conceitualmente diferenciados.

Este concurso de Geografia Humana foi mais uma mesa redonda ou um simpósio, tal a confluência de autoridade científica, tal o desembaraço e o desejo real de discutir o problema sem preconceitos apriorísticos como se observou ali. Longe desta tertúlia aquela malsinada técnica do argüidor de teses cuja primeira atitude é tentar pulverizar o candidato, num esforço traumatizante, baseado num ataque e na destruição sistemáticamente desenvolvidos. Nem apareceu, graças a Deus, aquela coisa realmente bizantina que andou perseguindo o professor Thiers Martins Moreira e o professor Celso Cunha, em concurso recente, e que se chama um caçador de acentos gráficos, um perseguidor de pronomes, um místico da sintaxe, enfim, um desses patuscos que não constroem nada, e que fazem da gramática e da gramatice uma oficina de prótese de ortopedia para compor o vazio de vocações literárias. Ausentes também os odontologistas da erudição geográfica entre os cinco componentes da banca: Christovam Leite de Castro, Alberto Lamego Filho, Pedro Calmon, Arthur Ramos e Carlos Delgado de Carvalho.

Coube ao professor Christovam Leite de Castro, iniciar a argüição. Levou para a banca a responsabilidade de toda um equipe de especialistas, uma vez que é o representante mais credenciado do pensamento científico do Conselho Nacional de Geografia. Revelou desde logo a intenção manifesta de ser rigoroso, levando seu rigor além dos limites de sua tradição de trato diplomático. Se com esta atitude surpreendente quis mostrar de público a isenção de seu julgamento, estamos certos de que o conseguiu, tal a sem-cerimônia e ofuror de que se achou possuído diante do candidato e da tese muito, embora, repetidamente, fustificasse sua atitude confessando que assim agia apenas para provocar a concorrente a reação que todos esperávamos de sua erudição, de sua técnica e de sua cultura. Mais uma vez obteve o seu intento. Vma enxurrada de argumentos lançados com a mesma violência pelo professor Josué de Castro, somada à invejável facilidade de expressão a que teremos de acrescentar grande capacidade de espírito crítico e uma pitada de bravura selvagem, foram de encontro aos desejos do argüidor.

Seremos, muito sereno, o professor Alberto Lamego Filho. Sua argüição foi desenvolvida no tom de conversa de rede, porem, profunda e percuciente. Era como se estivéssemos diante de uma grande e maciça erudiç̧ão a serviço de toda a malicia cabocla de que o gênio caipira é capaz. Não se enfureceu, não revelou decepções acabrunhantes diante da tese, não usou de subterfúgios argüindo, na tese, não as intenções do candidato ou aquilo que o candidato declara implicitamente não existir nela. Foi uma argüição conduzida com toda a técnica e, para sermos leais, teremos de admitir que poderia ter causado apreensões muito serias ao candidato, não fossem os recursos magníficos revelados por ele ainda nesta oportunidade com segurança, habilidade e franqueza.

Depois aconteceu o "caso Pedro Calmon" que na realidade é o "assunto Pedro Calmon". Creio que este meu amigo cultiva como um "ho66y" esta sua peregrina vocação de se transformar num assunto 
nacional com a mesma proporcionalidade em que o são o football e as reformas do ensino. Impunha-se a sua presença na banca. A tese, como imperativo de sua própria natureza, estava pontilhada de citações de ordem histórica. Em muitas de suas páginas a exposição foi conduzida segundo linhas mestras do método histórico, desde a analise da documentação exigida à técnica interpretativa empregada com grande sucesso pelo autor. Educado, culto e elegante, no que escreve, no que diz, no que faz, no que pensa. Pedro Calmon, eterno morgado no Petit Trianon, finge ter apetites de rústico lusitano à epiderme de sua formação nitidamente francesa, condimentada de tropicalismo baiano. Passeia pelas letras nacionais sua condição de herdeiro universal do espolio de mestre Afrânio Peixoto. Em fase destas virtudes aparentemente contraditórias, sua dialogação com Josué de Castro que poderia ter-se reduzido a um antagonismo entre a flamengofilia de um e a lusofilia de outro, teve gotas muito altas e concordantes. Josué de Castro reagiu à acusação de ser vítima de "endemia flamengófila nordestina" de que falava Pedro Calmon. Opôs documentos e argumentação técnica com grande propriedade e clareza.

Mestre Arthur Ramos confessou de início que não estava ali para julgar. Seu julgamento fora feito de longa data, em vista dos trabalhos clássicos do candidato, publicados em várias línguas, com o aplauso dos meios científicos do país e do estrangeiro. Aplaudiu no autor sua denuncia sobre as tendências totalitárias de certos geógrafos, desrespeitadores de campos alheios. Reclamou com elevado conceito a transformação em monografia das páginas da tese que se referiam à ecologia dos mocambos. Abandonando desde logo o comportamento inquisitorial que se atribui funcionalmente ao argüidor de tese de concurso. Arthur Ramos feriu, com aquela sua autoridade de chefe de escola, pontos cruciais dos problemas do homem brasileiro que tem sido sua desvelada preocupação de cientista.

O quinto argüidor foi o presidente da banca, professor Carlos Delgado de Carvalho. Iniciou sua peroração depois de ter, com muita elegância, tocado dezesseis vezes a campainha, marcando o tempo reservado aos argüidores e ao candidato. Deveria ter sido muito caro ao grande $e$ corajoso pioneiro dos modernos estudos geográficos no Brasil o desenrolar do concurso desde a magnifica prova de didática proferida pelo candidato até os últimos minutos de argüição na prova de defesa de tese. O concurso de Josué de Castro serviu também como um balanço rigoroso dos resultados dos esforços de Delgado de Carvalho pacientemente, persistentemente conduzidos em prol de renovação da metodologia geográfica e da didática da mesma ciência. Realizado há 20 anos atrás o desenrolar do concurso teria sido muito diferente.

Fonte: O GLOBO. Rio de Janeiro, 05 de abril de 1948.

Ressalte-se, todavia, que essa influência francesa não o restringiu tão somente a esta perspectiva. Reconhecia Humboldt, Ritter e Ratzel como grandes impulsionadores da moderna ciência geográfica e neles também se apoiava na sistematização das suas idéias. $\mathrm{Na}$ esteira desse processo herança, ao mesmo tempo em que evidencia a importância e intimidade com os mestres alemães utilizando e discutindo os princípios geográficos da extensão, coordenação e causalidade, como mostrado no capitulo anterior, Josué demonstra entender que o fenômeno que constituía-se no cerne das 
suas preocupações, tem suas modalidades geográficas e as dicotomias locais ligam-se à totalidade dos traços do complexo geográfico, sejam naturais ou humanos, constituindo uma descrição dos gêneros de vida.

A legibilidade desta perspectiva fizera-lhe adotar o método geográfico como referência, especialmente por vê-lo "quase (...) como uma técnica que ensina a ver e a produzir com fidelidade os vários elementos que compõem os diversos panoramas naturais" (1951: 545), bem como discutir a disciplina demonstrando preocupações epistemológicas que vão das bases conceituais ao seu objeto de estudo. Em artigo escrito para o Boletim Geográfico, em 1951, destacou

Não há disciplina científica cujo conceito tenha variado tanto através dos tempos como a geografia, apesar de ter sempre um mesmo campo de estudo a superfície da terra. Simples catálogo enumerativo dos lugares, na antiguidade; traçado do itinerário das terras conquistadas, no tempo dos romanos; o espelho mágico do mundo na era das grandes descobertas, a geografia tornou-se hoje uma ciência complexa, a mais enciclopédica e universalista das ciências (CASTRO, 1951, p. 545).

Nesse mesmo artigo discute o objetivo da disciplina e reclama uma Geografia una a despeito das diferentes divisões impostas pelo processo de especialização das ciências. No seu entender,

O estudo da paisagem - tanto da paisagem natural, produto exclusivo das forças físicas trabalhando a superfície do planeta, como da paisagem cultural, resultado da interferência do elemento humano, alternando a paisagem natural, criando fatos novos, modelando uma paisagem humanizada-é, em ultima análise o objetivo essencial da geografia, desta geografia moderna, que acabou com as barreiras artificiais que a dividiam totalmente em geografia física e geografia humana, em geografia geral e geografia regional" (CASTRO, 1951, p. 545).

Para o autor essa discussão era salutar em face ao papel que cabia a Geografia na elaboração do pensamento moderno, uma vez que viera multiplicar a densidade de percepção do homem, abrindo com os seus métodos, perspectivas novas ao conhecimento de fatos que durante séculos foram apenas vistos, mas não compreendidos. Portanto, "diante do irremediável divórcio entre a Física e a Filosofia Construtiva, o único caminho pelo qual as ciências naturais poderão alcançar o elevado plano das especulações filosóficas, é o caminho unificador da Geografia - de uma 
Geografia filosófica - a qual procure situar o homem e a terra num universo menos transcendente, sem a riqueza dimensional e conceitual da Física moderna, porém, mais na medida do humano, na medida do compreensível pela inteligência humana" (CASTRO, 1951, p. 546).

Ao trazer essas questões, Josué de Castro suscitara outras tantas, mas vai mesmo se distinguir pelo desenvolvimento de uma Geografia de contestação e combativa dos métodos de exploração social e econômica, malgrado as abordagens centradas no naturalismo exacerbado das análises regionais do pensamento geográfico clássico, que tinha dificuldades de incorporar o social dentro de seu paradigma teórico. Assumindo, portanto, um temário que não constava no elenco a ser analisado por um geógrafo e por conseguinte, era tido como não geográfico. A propósito, no prefácio de "Geopolítica da Fome" delata,

A geografia, em seu sentido usual, sempre tratou muito mais dos aspectos positivos e favoráveis do mundo que de seus aspectos negativos - mais das riquezas da terra e das vitórias do homem dos que de suas misérias e de seus fracassos. A chamada Geografia Humana - ciência dos nossos dias encarrega-se de apresentar os brilhantes resultados da epopéia do trabalho do homem escrita na superfície da Terra. De registrar tudo o que o homem fez, alterando o meio natural, como um verdadeiro agente geográfico. (CASTRO, 1968, p. 25).

A despeito da Geografia que abraçara, voltada a outro aspecto das relações do homem com o meio, tratando exatamente, daquilo que o homem não fez, não soube ou não quis fazer. Tratava das possibilidades geográficas que ele não aproveitou ou que malbaratou. Não era, pois, uma geografia das grandezas humanas, mas uma geografia de suas misérias. 'Uma geografia de trágicas singularidades, na qual se estudava não a terra que dá de comer ao homem, mas o homem servindo apenas para alimentar a terra (CASTRO, 1968, p. 25).

Trilhando por essa perspectiva Josué findou por se privar de um contato mais amiúde com a comunidade geográfica brasileira, não chegando sequer a freqüentar as famosas assembléias anuais da AGB. Não era bem visto por uma parte dessa comunidade, não apenas por questões teóricas, mas também por questões de ordem pessoais derivadas das múltiplas atividades que 
desenvolvia, a proximidade com o poder, o prestígio desfrutado em outros meios. Pode-se aqui aludir como exemplo a repercussão da sua posse na Cátedra de Geografia Humana da Faculdade Nacional de Filosofia, na imprensa carioca e brasileira. Desde da divulgação à cobertura da solenidade.

Foto 02 - Solenidade de Posse de Josué de Castro na Cátedra de Geografia Humana da Faculdade Nacional de Filosofia da Universidade do Brasil em 14 de julho de 1948

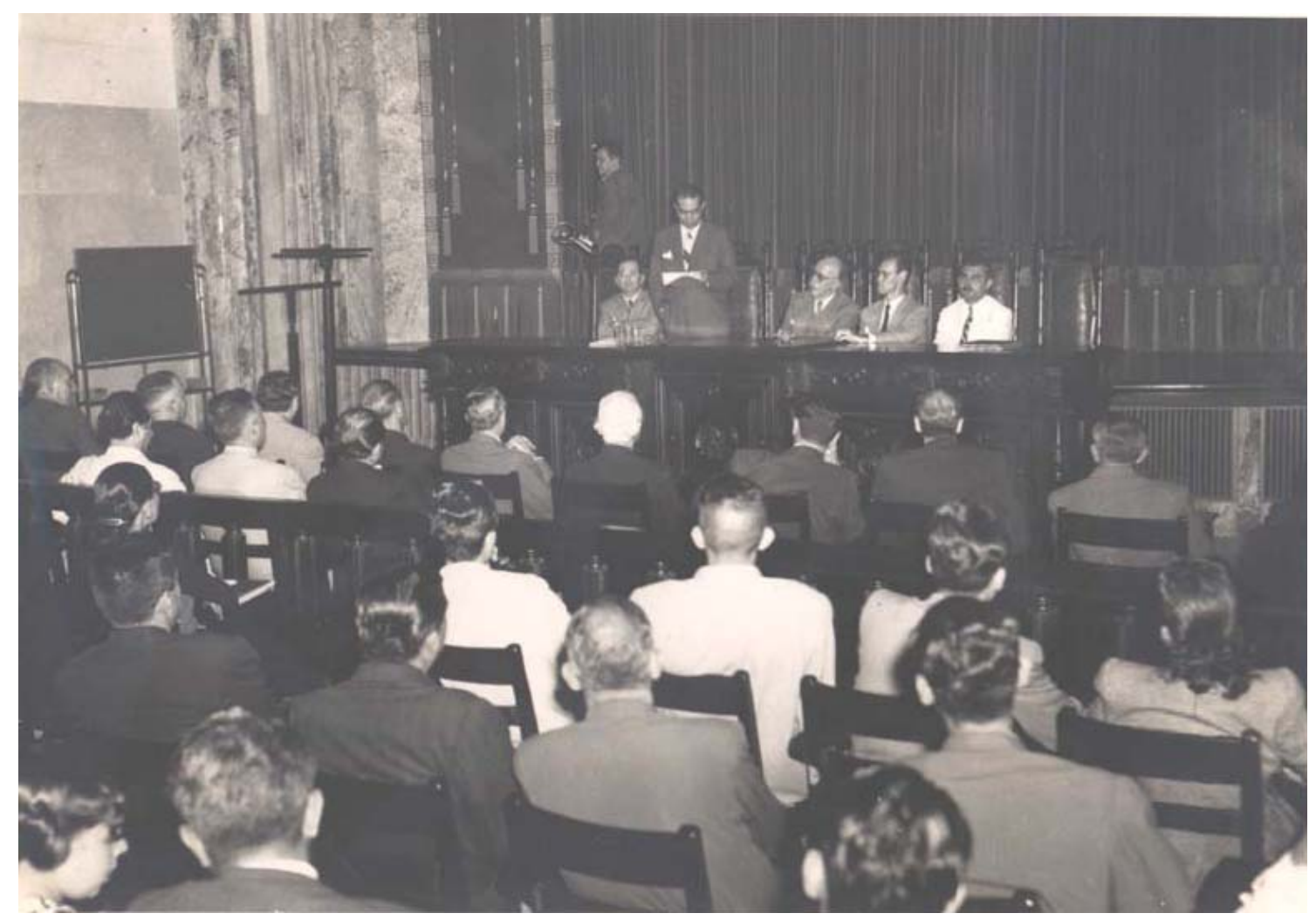

Fonte: Acervo do Centro Josué de Castro - Recife/PE

Quadro 12 - Posse de Josué de Castro na Cátedra de Geografia Humana da Faculdade Nacional de Filosofia da Universidade do Brasil - I

A Lição do Professor Josué de Castro - na posse do professor Josué de Castro, que foi na verdade uma bela e festiva cerimônia de inteligência e onde rebrilharam as qualidades intelectuais do novo catedrático, os alunos tiveram a oportunidade de ouvir uma aula-conferência ministrada pelo recém-empossado que, fôra o brilho e a eloqüência com que foi pronunciada, constituiu um preciosa lição sobre Geografia Humana e as Finalidades das Universidades. Também o professor Arthur Ramos saudando o seu colega Josué de Castro não the poupou elogios à obra e à vida de professo. Em nome do Grêmio "José do Patrocínio" pronunciou brifhante oração, o estudante José Ribamar.

Fonte: DIARIO DA NOITE. Rio de Janeiro, 16 de junho de 1948. 
Quadro 13 - Posse de Josué de Castro na Cátedra de Geografia Humana da Faculdade Nacional de Filosofia da Universidade do Brasil - II

\section{O Prof. Josué de Castro Catedrático da Faculdade Nacional de Filosofia}

Rio, 16 (Meridional) - tomou posse da cátedra de Geografia Humana da Faculdade $\mathcal{N a c i o n a l ~ d e ~}$ Filosofia, da qual já era professor, o sr. Josué de Castro. O ato revestiu-se de brilhantismo e foi presidido pelo professor Azevedo Amaral. O discurso oficial foi feito pelo professor Artur Ramos.

O professor Josué de Castro, cujo livro "Geografia da Fome" recebeu o premio de 1947 da Sociedade Brasileira de Escritores, formou-se em medicina 1929, sendo por essa ocasião presidente do Centro Universitário Latino-Americano. Em 1932, obteve, por concurso, o lugar de livro docente de filosofia da Faculdade de Recife e no ano seguinte o de professor de Geografia Humana. Destacouse, apesar de muito jovem, como um dos nossos primeiros especialistas em nutrição, e nesse campo de investigação é hoje de notoriedade mundial. Ainda recentemente foi eleito para o conselho permanente da FAO, organismo da ONV integrado de 35 paises. Nele representa o professor brasileiro a América Latina.

Fez ele concurso para cátedra de que foi empossado com uma tese sobre Geografia Vrbana, publicada agora em volume, pela Imprensa Nacional, so6 o título de "Fatores da Localização da cidade do Recife".

Fonte: DIARIO DE PERNAMBUCO. Recife, 17 de junho de 1948.

Quadro 14 - Posse de Josué de Castro na Cátedra de Geografia Humana da Faculdade Nacional de Filosofia da Universidade do Brasil - III

\section{Vma Festa de Cultura}

o professor Josué de Castro foi solenemente empossado na cátedra da Faculdade de Filosofia - Os oradores - O elogio do novo mestre, pelo prof. Artur Ramos - Como se manifestou o Reitor da Universidade

Foi uma verdadeira festa de amizade e cultura a solenidade da posse, verificada, ontem, no Salão Nobre da Faculdade Nacional de Filosofia, do professor Josué de Castro, na cátedra de Geografia Humana do Curso de Jornalismo, daquele estabelecimento de ensino superior. Viviam-se, ali, destacados elementos dos círculos culturais e da sociedade, inclusive o corpo docente da Faculdade, bem como alunos dos seus diferentes Cursos. A solenidade foi presidida pelo sr. Inácio Azevedo Amaral, reitor da Universidade do Brasil, tendo constituído a mesa, ainda, srs. Ernesto Faria e Heitor Corrêa, respectivamente, diretor interino e secretario da aludida Faculdade bem assim o professor Artur Ramos, catedrático de Antropologia, saudou o sr. Josué de Castro.

Depois de ter lido o têrmo de posse e sido feita a entrega do título de nomeação, o diretor da Faculdade Nacional de Filosofia, em nome da mesma, passou ás mãos do sr. Josué de Castro, o diploma de Doutor em Geografia e História.

Ao professor Artur Ramos, coube receber o novel catedrático, fazendo o seu elogio. Disse do brilho 
de seu concurso e relembrou ter acompanhado desde a Bafia a atuação do professor Josué de Castro como cientista e escritor. Referiu-se ás suas atividades como nutricionista e, depois, no setor social, estudando o problema da educação do homem em bases científicas. Chamou-o de mestre da ciência da nutrição, para então aludir á Geografia Humana - cátedra na qual se empossava o sr. Josué de Castro - como o estudo da compreensão e valorização do homem. Depois de outras considerações, concluiu dizendo que o sr. Josué de Castro é o homem sempre empolgado pelos problemas sociais de nosso tempo.

\section{Fala um Aluno}

Por delegação de seus companheiros de curso e também por delegação do Grêmio "José do Patrocínio", saudou o professor Josué de Castro, o estudante do curso de Jornalismo, José Ribamar Machado, que exaltou as qualidades do mestre e do escritor fluente e seguro, é o sr. Josué de Castro.

\section{Congratulações do Reitor}

A essa altura usou da palavra o professor Inácio Azevedo Amaral, congratulando-se com o professor Josué de Castro, em nome da Universidade do Brasil e em seu próprio nome, pela sua posse na cátedra de Geografia Humana. Disse que foi a luta vitoriosa contra todas as circunstâncias que assinalou a trajetória do sr. Josué de Castro como homem e cientista.

\section{O Discurso do Mestre}

O professor Josué de Castro está, agora, com a palavra. Referiu-se inicialmente ao "amor intelectual" a que aludiu Spinosa e, dirigindo-se ao "magnífico reitor da Universidade do Brasil" disse da sua admiração pelo mestre. "Sois - declarou - um grande selecionador de homens". Não quis elogiar a "capacidade do plástico diante da vida, mas a do compreendedor do homem. Sois um homem rebelde contra os preconceitos e isso constitui a sua marcante personalidade. Sois um homem magnífico pelas virtudes e pelos defeitos".

O orador faz o elogio do senhor Artur Ramos, seu amigo de muitos anos. Fez sentir a amizade que The dedica. Confessa a influência exercida pelo mesmo, na sua formação científica. Lê uma página de seu "diário" de estudante, à época em que era companheiro de pensão daquele. Profere ainda algumas palavras de carinho para o amigo que influiu decididamente em sua carreira acadêmica.

Agora, o sr. Josué de Castro faz referencias ao sr. Roquete Pinto, paraninfo daquela festa de amizade e cultura. Elogiou o homem que muito concorreu para que ele - o orador se tornasse catedrático, pois por aquele fôra indicado para lecionar antropologia na Universidade do Distrito Federal. Outras considerações, e o professor Josué de Castro afirma que aquêle momento tem a significação de tôda uma existência. Quase finalizando sua peroração, reafirmou que a Geografia é a mais universalista das ciências e teceu judiciosos comentários a respeito.

Fonte: O MUNDO. Rio de Janeiro, 15 de junho de 1948. 
Assim, Josué se manterá relativamente afastado da comunidade geográfica brasileira, enquanto estreita os laços com os colegas norteamericanos e franceses, como Max Sorre, com quem participara da Comissão de Geografia Médica da União Geográfica Internacional - UGI (vide correspondência de Jacques M. May); Francis Ruellan (amigo e colega na Faculdade Nacional de Filosofia), Jean Dresch e Jean Tricart, com os quais mantivera contato até o fim da vida, como pode ser visto nas correspondências que seguem ${ }^{39}$. Também com Pierre Deffontaines, manteve contato constante desde os anos 30 , igualmente ao que acontecera com o norte-americano Preston James, cuja presença mostra-se marcante na obra de Josué. No Brasil, a partir da década de 1940, passa a dialogar com Milton Santos e outros geógrafos nordestinos como Manuel Correia de Andrade e Mário Lacerda de Melo.

Se manterá na Cátedra de Geografia Humana da Faculdade Nacional de Filosofia até 1954, quando se elege Deputado Federal pelo PTB de Pernambuco, mandato que seria renovado quatro anos depois e ao término do qual assumiria a Embaixada do Brasil em Genebra.

39 Josué de Castro vem a falecer em setembro de 1973 em Paris, onde ficou exilado em seguida ao golpe militar de 31 de março de 1964. 
Correspondência do Professor Jacques M. May para o Professor Josué de Castro. 
Correspondência do Professor Jean Dresch para o Professor Josué de Castro. 
Correspondência do Professor Jean Tricart para o Professor Josué de Castro. 
Fanejear te ki ressour

Josue de CAstro

aux bans solns de

1. 'Ambararde du Brëa11

Avenue Vontalgne = PARTs

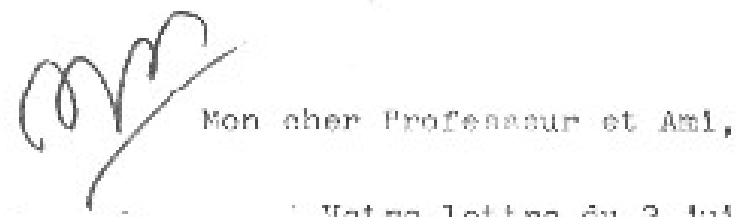

Votre lettre du 2 Juln a mla 22 jours pour me parverir, ce cul est évidemmenent un record, si blen que je n'al pu vous répoalre a Rome, malo, puisque vouso seres a Paris en Julliet, je vous envole cet te lettre a l'Ambarasde du Bréll, comme vous me l'avez demande.

Notre Ambasadeur, $v_{3}$ nsleur Gurdion, eat i far1a, encore probalement pour quelques jourz et je me perceta de voug sukféror to be volr, puieque c'ent lut quil miavait d1.t que l'ineonvónlent d'une fonction internet lorale ne 1u1. paralegalt oas un empechement majeur. Tous avez fort hien falt d'en nar'er ald comte de B11.7 et fe rouf conset.lle de volr également notre aml Ronze que j'al jó ja. Hi du courant. J'nl, panjé récemment au chareg d'Arfalreg de France, fonsieur Le Geniseel, afin qu'il fut inforié.

J'espörś que roua aurona rapldemsnt une solution dul me fera paraonneliament un tres grand plalalr, car veus mérltes larement cetto oblainetion:

To pare er solr pour Munaug travalilor en coliutotation dvec I'Iratitit de Recharches sur l'Asazonle. J'eapere avolr le plaisir de remoontrer notre am1 commun, hrtiur Reals.

De ménage à ménage, rasevez nos me1llellres am1tiéa et notre trièg amtanl aouvents.

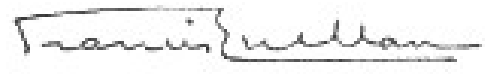

Frencis Rutertan 
Correspondência do Professor Preston James para o Professor Josué de Castro. 
Correspondência do Professor Preston James para o Professor Josué de Castro. 
Correspondência do Professor Josué de Castro para o Professor Milton Santos. 
Correspondência do Professor Milton Santos para o Professor Josué de Castro. 


\section{Capítulo - Geografia da Fome - Consubstanciação e Matriz dos Estudos sobre a Fome no Brasil e na História do Pensamento Geográfico Brasileiro}

Até o seu afastamento definitivo da Cátedra de Geografia Humana da Faculdade Nacional de Filosofia em 1954, Josué de Castro havia produzido cinco importantes obras de maior interesse geográfico: (1) A Alimentação Brasileira à Luz da Geografia Humana (1937); (2) Geografia Humana - Estudo da Paisagem Cultural do Mundo (1939); (3) Geografia da Fome (1946); Fatores de Localização da Cidade do Recife (1948), e Geopolítica da Fome (1951). Porém é com Geografia da Fome que o autor vem a se afirmar em definitivo como um pensador do seu tempo, como médico, mas, sobretudo, como geógrafo. Repare-se que o trabalho principiado nove anos antes, chegara ao seu ápice, partindo-se do princípio que Geografia da Fome tornara-se uma referência e, como dito em páginas anteriores, um imperativo no estudo da fome. Ou dito de outra forma, uma matriz, a principal matriz dos estudos sobre a fome no Brasil e, por conseguinte, na história do pensamento geográfico brasileiro. Assinala a introdução do tema na disciplina, que vai ser utilizada por Josué como um meio eficaz para denunciá-la.

Nessa perspectiva rompe com o silêncio em torno da fome e com os paradigmas que a explicavam como um fenômeno natural. Ele vai apontar este espectro e a miséria que assolam o país como conseqüências das estruturas sociais defeituosas historicamente herdadas e nesse sentido, irá instituir uma nova forma de analisar estes fenômenos, elucidando as razões pelas quais não se explica o país, como as coisas se processaram, porquê e os seus efeitos.

Esta análise inaudita, permeada de delato causara grande impacto quando do seu lançamento. A propósito, em matéria para o jornal Correio Paulistano, em 22 de janeiro de 1947, escrevera Nelson Werneck Sodré 
Trata-se de um trabalho feito com segurança, baseado em demoradas pesquisas e cujas conclusões, se disentíveis por vezes, merecem sempre atenção. Especialista em nutrição, o autor não é um desses estudiosos que se deixa obcecar, por uma face do problema, sacrificando-Ihe a sua riqueza de conteúdo e as contribuições que os demais ângulos podem oferecer.

Geografia da Fome, na verdade, representa concretamente, um momento importante na obra do autor. Percebe-se a preocupação de refinar o conceito de fome, o que marca uma mudança em relação à produção anterior. "Se, em seus primeiros escritos, a fome, a subnutrição e o problema alimentar aparecem, freqüentemente como sinônimos, neste último trabalho Josué de Castro explora, exatamente, o eixo principal de suas formulações (...) O livro demonstra, ainda, que algumas reorientações em seu pensamento que, para maior compreensão, necessita de uma aproximação não só com a trajetória pessoal do autor, como também com as mudanças na conjuntura histórica e social do País nos primeiros anos da década de 40" (MAGALHAES, 1997, p. 45).

Logo no prefácio, destaca o autor, ser assunto do livro bastante delicado e perigoso e, por assim ser, era tido como tabu. Destacava ainda, ser "estranho e chocante num mundo como o nosso, caracterizado por tão excessiva capacidade de escrever-se e de publicar-se, haja até hoje tão pouca coisa escrita acerca do fenômeno da fome em suas diferentes manifestações" (CASTRO, 1967, p. 11). Ao buscar desvendar os motivos desse silêncio, Josué adentra nas verdadeiras causas da fome e começa mostrá-la como uma praga fabricada pelo homem, concebendo o caso brasileiro como conseqüência de um passado histórico marcado pela exploração desde os tempos coloniais, que ensejara uma situação de desajuste econômico e social. Situação que se agravaria nos tempos mais recentes com a inoperância do Estado, que a despeito dos interesses sociais, estava mais voltado aos interesses privados e dos monopólios estrangeiros. Conclui, assim, que

A fome no Brasil, que perdura, apesar dos enormes progressos alcançados em vários setores de nossas atividades, é conseqüência, antes de tudo, de seu passado histórico, com os seus grupos humanos, sempre em luta e quase nunca em harmonia com os quadros naturais (...) por inabilidade do elemento colonizado, indiferente a tudo que não significasse vantagem direta e imediata 
para os seus planos de aventura mercantil. Aventura desdobrada em ciclos sucessivos de economia destrutiva (...) (CASTRO, 1967, p. 264).

Analisando e procurando alternativas para superação das realidades emanadas desse processo, Josué mapeou a fome no país e identificou três tipologias distintas de fome - fome endêmica, epidemias de fome e subnutrição configuradas nas cinco áreas por ele delimitada: Amazônia, Nordeste Açucareiro, Sertão Nordestino, Centro-Oeste e Extremo Sul, cada uma apresentando uma dieta alimentar peculiar condicionada pelos fatores históricos e culturais (Mapa 2).

\section{MAPA 02 - ÁREAS ALIMENTARES DO BRASIL}

\section{Organizado por Josué de Castro}

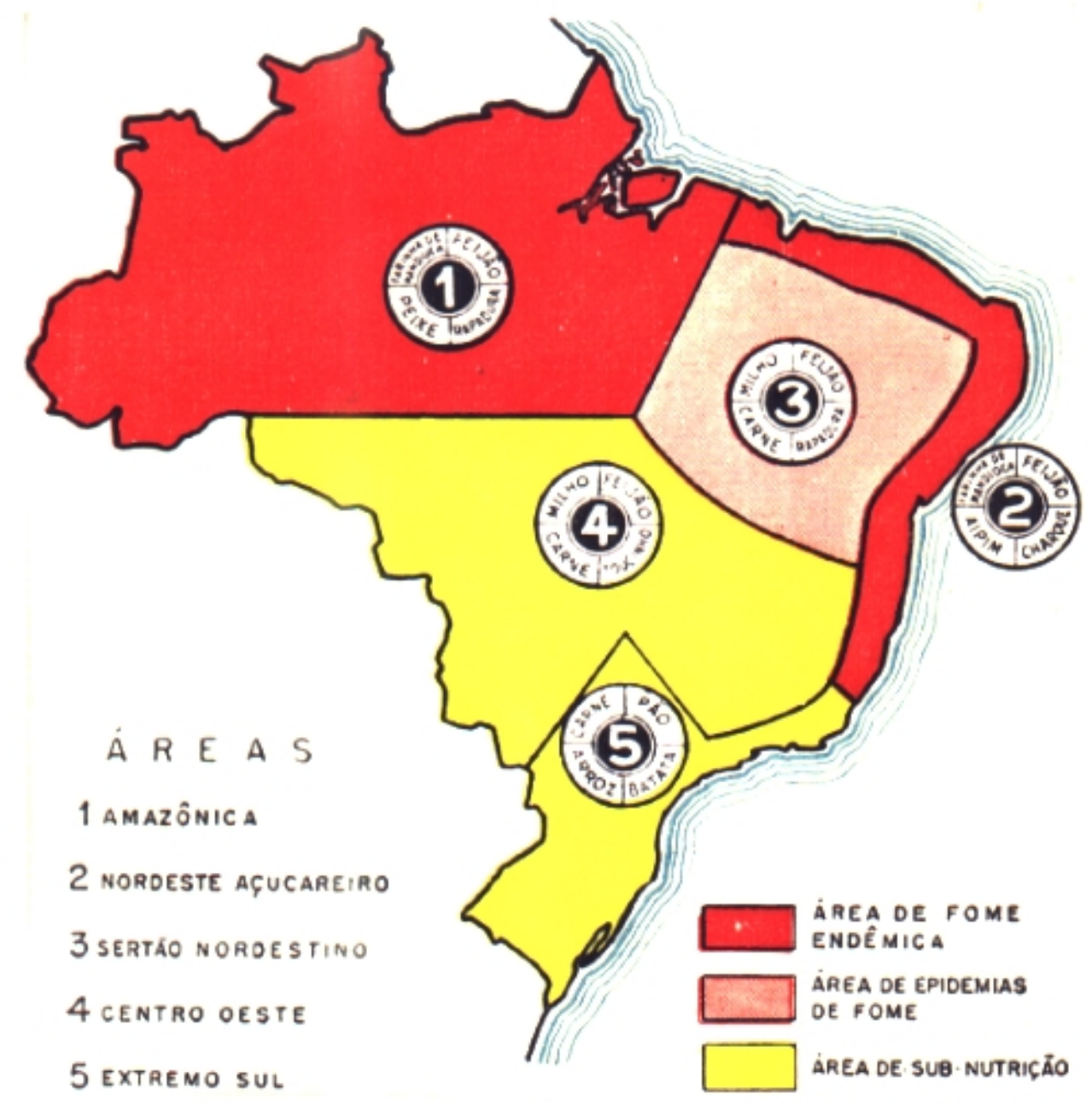


Fonte: CASTRO, Josué de. Geografia da Fome - o dilema Brasileiro: pão ou aço. 10 ed. São Paulo: Brasiliense, 1967.

Certamente este foi o primeiro mapa da fome feito no Brasil, não obstante o esboço apresentado em A Alimentação Brasileira à Luz da Geografia Humana. A partir dele Josué também identificou e espacializou as principais carências alimentares (mapa 3 ) e mostrou que em qualquer uma das cinco áreas que compunham o mosaico alimentar brasileiro não se dispunha de todas as substâncias essenciais ao metabolismo basal. Assim, em uma região onde a carne é a principal fonte de alimentação, o teor de proteínas predomina em detrimento de outras substâncias que estão ausentes ou em pequena quantidade na mesma, ao passo em que numa outra região, onde o aipim é a ração mais freqüente, são substanciais os níveis de carboidrato, havendo conseqüentemente, deficiência relativa de lipídios, vitaminas e outros nutrientes específicos. Portanto, de acordo com o tipo de alimentação, os níveis séricos e tissulares de certa substância alimentar estarão em maior ou menor quantidade, revelando o grau de desnutrição e as patologias derivadas da ausência dos mesmos.

Rumando nessa perspectiva, provou que qualquer tentativa de mostrar a fome como um fenômeno natural, que obedece a uma lei especifica da natureza, não faz qualquer sentido e, que o estudo do seu quadro carece de bases geográficas como provou através do livro Geografia da Fome, que não por acaso tornou-se um significativo aporte ao seu estudo. 


\section{MAPA 03 - PRINCIPAIS CARÊNCIAS EXISTENTES NAS DIFERENTES ÁREAS ALIMENTARES DO BRASIL}

Organizado por Josué de Castro

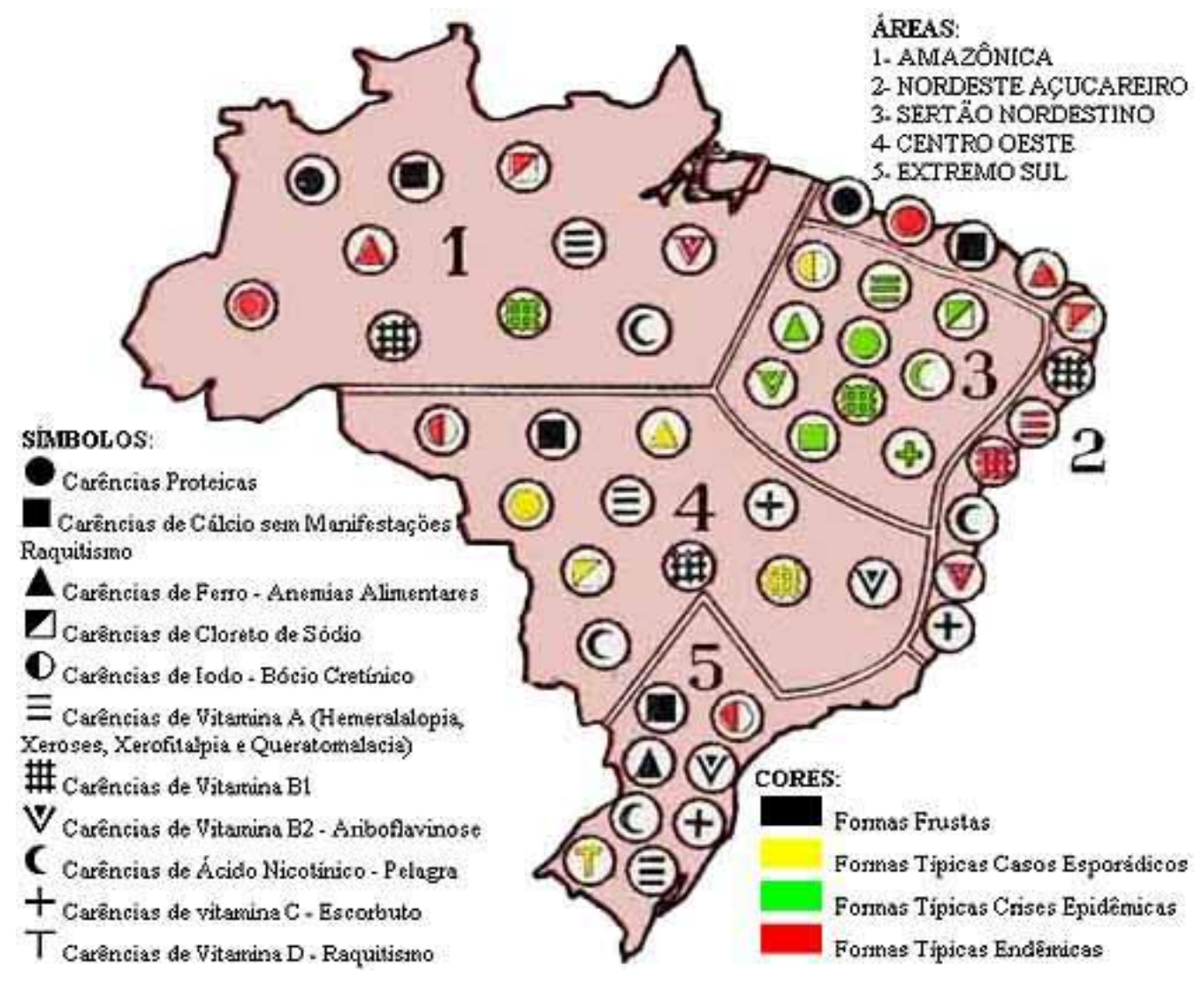

Fonte: CASTRO, Josué de. Geografia da Fome - o dilema Brasileiro: pão ou aço. 10 ed. São Paulo: Brasiliense, 1967. 


\section{CONSIDERAÇÕES FINAIS}

O percurso trilhado pela Geografia no Brasil a partir da sua institucionalização, em 1934, revela continuidades e descontinuidades resultantes das texturas subjacentes a sua própria construção. Desconstruir esse processo e decifrar as suas especificidades constitui uma importante pista para conhecer e compreender a geografia brasileira. Aí, é possível encontrar e reencontrar importantes matrizes da disciplina que diante da pressa ajusta-se aos novos tempos acabara por olvidá-los, ignorando a sua contribuição.

Desde os seus primeiros tempos, em maior ou menor intensidade e independente dos princípios, a geografia brasileira tem tematizado o fenômeno social. Porém, não foram muitos aqueles que avançaram de forma sistemática na análise desse fenômeno, como fizera Josué de Castro ao desencastelar a fome e conferir-Ihe fórum social. Trazendo ademais uma análise acerca das "múltiplas formas de ações negadoras da possibilidade de estabelecimento de um padrão de organização social e modos, pelos setores preponderante sobre os demais" (REZENDE, 2005, p. 25), que tivesse entre os seus principais objetivos o florescimento de práticas desmanteladoras das exclusões (sociais, econômicas, culturais etc.) perpetradas, continuamente através de diversos modos pelos quais setores preponderantes sobre os demais.

Dessa forma, pode-se afirmar que o pensamento é paradigmático, na medida em que desenvolve uma leitura do problema nacional sem deter-se apenas a questão alimentar.

Contudo, através da literatura mais recente, pode-se perceber que a despeito da sua atualidade, a fome tem estado cada vez mais distante da geografia, pouco sendo estudada pelos geógrafos nos últimos decênios. No dizer de Monteiro (2000, p. 160), de um tempo não tão remoto (anos quarenta do século passado), e do próprio Brasil, a temática da fome tão brilhantemente abordada por Josué de Castro em suas obras Geografia da Fome e Geopolítica da Fome, de grande projeção e edição internacional não tem seguidores entre 
nós. Quer dizer, a obra de Josué não teve um desdobramento e com toda a sua importância esteve ameaçada de cair no esquecimento. Na passagem do decênio de 80 para 90, foi esboçado um 'retorno' ao autor por parte de alguns segmentos das classes intelectual, artística e religiosa quando lideraram campanhas ou movimentos concernentes a fome, a miséria e ao meio ambiente e cidadania, como a "Ação da Cidadania contra a Fome, a Miséria e pela Vida" sob a liderança do sociólogo Herbert de Souza - Betinho; "Ano 2000 sem Miséria", comandada pelo arcebispo emérito de Olinda e Recife Dom Hélder Câmara e o movimento "Manguebeat" liderado pelo músico pernambucano Chico Science.

Praticamente nesse mesmo período o autor começa a ser (re)descoberto por pesquisadores e estudiosos de diversas áreas do conhecimento que buscam nele fundamentação necessária ao desenvolvimento de novos trabalhos acerca dos temas por ele contemplados, afora outros destes emanados e que se constituem em fontes indispensáveis de consultas para a leitura do mundo contemporâneo e, especialmente do Brasil. O quadro a seguir mostra o que foi produzido sobre Josué, desde o pioneiro trabalho de Magalhães (1992) a até a tese de Campos (2004).

Vale chamar a atenção para o fato de nenhum dos trabalhos enumerados tratar da geografia da fome especificamente, mesmo aqueles desenvolvidos por geógrafos (MARCHI, 2004 NUNES, 2003; CARVALHO, 2001). Tratam-se de análises amplas que buscam contemplar o autor na sua inteireza, contextualizado-o. Ou ainda, tratando de temas específicos, como no caso de Campos (2004) ao identificar e analisar a dimensão populacional na sua oba. 
Quadro 15 - Produção Acadêmica Sobre Josué de Castro

\begin{tabular}{|c|c|c|c|c|c|}
\hline AUTOR & TRABALHO & ÁREA & TIPO & IES & ANO \\
\hline Rosana Magalhães & $\begin{array}{l}\text { A Fome no Pensamento de } \\
\text { Josué de Castro }\end{array}$ & Saúde & Dissert. & FIOCRUZ & 1992 \\
\hline $\begin{array}{l}\text { Luís Carlos Ramos } \\
\text { Tavares }\end{array}$ & $\begin{array}{l}\text { A Inserção da Obra de Josué } \\
\text { de Castro no Pensamento } \\
\text { Geográfico }\end{array}$ & Geografia & Monog. & UNB & 1997 \\
\hline Patrícia M. Domingos & $\begin{array}{l}\text { Resgate da vida e obra de } \\
\text { Josué de Castro }\end{array}$ & Saúde & Monog. & $\begin{array}{l}\text { USP } \\
\text { (ESP) }\end{array}$ & 1997 \\
\hline $\begin{array}{l}\text { Dorival Donizeti } \\
\text { Marchi }\end{array}$ & $\begin{array}{l}\text { O Pensamento Geográfico de } \\
\text { Josué de Castro nas Décadas } \\
\text { de } 40 \text { e } 50: \text { a fome e a } \\
\text { produção de alimentos }\end{array}$ & Geografia & Monog. & $\begin{array}{l}\text { UNESP } \\
\text { (RC) }\end{array}$ & 1998 \\
\hline $\begin{array}{l}\text { Tânia Elias M. da } \\
\text { Silva }\end{array}$ & $\begin{array}{l}\text { Josué de Castro: Por uma } \\
\text { Poética da Fome }\end{array}$ & C. Sociais & Tese & PUC-SP & 1998 \\
\hline $\begin{array}{l}\text { Renato Cavalheira do } \\
\text { Nascimento }\end{array}$ & $\begin{array}{l}\text { Josué de Castro: O Teórico do } \\
\text { Mangue }\end{array}$ & Sociologia & Monog. & UNB & 1999 \\
\hline $\begin{array}{l}\text { Antônio Alfredo Teles } \\
\text { de Carvalho }\end{array}$ & $\begin{array}{l}\text { Josué de Castro na } \\
\text { Perspectiva Da Geografia } \\
\text { Brasileira - } 1934 / 1956 \text { : Uma } \\
\text { Contribuição a Historiografia } \\
\text { do Pensamento Geográfico } \\
\text { Nacional }\end{array}$ & Geografia & Dissert. & UFPE & 2001 \\
\hline Fábio Tozi & $\begin{array}{l}\text { Geografias da Desigualdade - } \\
\text { Território e Fome }\end{array}$ & Geografia & Monog. & UNICAMP & 2001 \\
\hline $\begin{array}{l}\text { Renato Cavalheira do } \\
\text { Nascimento }\end{array}$ & $\begin{array}{l}\text { Josué de Castro - O Sociólogo } \\
\text { da Fome }\end{array}$ & Sociologia & Dissert. & UNB & 2002 \\
\hline Jorge Luís R. Nunes & $\begin{array}{l}\text { Josué de Castro, O Geógrafo } \\
\text { da Fome - Uma Abordagem } \\
\text { Crítica da Obra e sua Relação } \\
\text { com o Contexto Econômico e } \\
\text { Político do Brasil }\end{array}$ & Geografia & Dissert. & UFRGS & 2003 \\
\hline $\begin{array}{l}\text { Dorival Donizeti } \\
\text { Marchi }\end{array}$ & $\begin{array}{l}\text { O Pensamento de Josué de } \\
\text { Castro }\end{array}$ & Educação & Dissert. & USF & 2004 \\
\hline $\begin{array}{l}\text { Rui Ribeiro de } \\
\text { Campos }\end{array}$ & $\begin{array}{l}\text { A Dimensão Populacional na } \\
\text { Obra de Josué de Castro }\end{array}$ & Geografia & Tese & $\begin{array}{l}\text { UNESP } \\
\text { (RC) }\end{array}$ & 2004 \\
\hline
\end{tabular}

Fonte: Pesquisa Direta

Organização: Antônio Alfredo Teles de Carvalho - 2005/2007 


\section{BIBLIOGRAFIA}

ABRANTES, Vera Lúcia Cortes. Fragmentos de Memória das Pesquisas Geográficas de Campo no IBGE (1939 - 1968): imagens e representações numa abordagem da história oral. Dissertação (Mestrado). Universidade Federal do Estado do Rio de Janeiro. Rio de Janeiro, 2000.

ABREU, Maurício de Almeida. O Estudo Geográfico da Cidade no Brasil: evolução e avaliação. In: CARLOS, Ana Fani. A. (Org.) Os Caminhos da Reflexão sobre a Cidade e o Urbano. São Paulo: Edusp, 1994. p. 199-232.

ALMEIDA, Roberto Schmidt de. A Geografia e os Geógrafos do IBGE no Período de 1938 - 1998. Tese de Doutoramento (Programa de PósGraduação em Geografia). Centro de Ciências Matemáticas e da Natureza UFRJ. Rio de Janeiro, 2000.

AMARAL, Raquel Maria Fontes do. A Geografia e as Bases da Formação Nacional Brasileira: Uma Interpretação Fundamentada nas Idéias de Ignácio Rangel. Tese de Doutoramento (Programa de Pós-Graduação em Geografia). Faculdade de Filosofia, Letras e Ciências Humanas - USP. São Paulo, 1997.

ANDRADE, Manuel Correia de. Uma Geografia para o Século XXI. Recife: CEPE, 1993.

ANTONIO FILHO, Fadel D. A Visão sobre a Amazônia Brasileira: Uma Avaliação do Pensamento Geográfico entre 1900 - 1940. Tese de Doutoramento (Programa de Pós-Graduação em Geografia) Instituto de Geociências e Ciências Exatas - UNESP. Rio Claro, 1996.

O Pensamento Geográfico de Euclides da Cunha. Dissertação (Mestrado) Instituto de Geociências e Ciências Exatas - UNESP. Rio Claro, 1990.

ANSELMO, Rita de Cássia M. de S. Geografia e Geopolítica na Formação Nacional Brasileira - Everardo Adolpho Backheuser. Tese de Doutoramento (Programa de Pós-Graduação em Geografia) Instituto de Geociências e Ciências Exatas - UNESP. Rio Claro, 2000.

Oliveira Vianna e a Unidade-Identidade do Espaço Brasileiro. Dissertação (Mestrado) Instituto de Geociências e Ciências Exatas - UNESP. Rio Claro, 1995.

ANTUNES, Charlles da França. Os Estudantes e a Construção da Geografia Brasileira: um Encontro nos Encontros Nacionais de Estudantes de Geografias. Dissertação (Mestrado). Universidade Federal Fluminense. Niterói, 2001. 
BAUAB, Fabrício Pedroso. Da Geografia Medieval às Origens da Geografia Moderna: Contrastes entre Diferentes Noções de Natureza, Espaço e Tempo. Tese de Doutoramento (Programa de Pós-Graduação em Geografia) Faculdade de Ciência e Tecnologia - UNESP. Presidente Prudente, 2005.

BERNARDES, Nilo. A Influência Estrangeira no Desenvolvimento da Geografia no Brasil. In: Revista Brasileira de Geografia. Rio de Janeiro, v. 44, n. 3, p. 519-527. jul/set, 1982.

BESSA, Vagner de Carvalho. Território e Desenvolvimento: as Ideologias Geográficas no Governo J. K. (1965 - 1960). Dissertação (Mestrado) Faculdade de Filosofia, Letras e Ciências Humanas - USP. São Paulo, 1994.

BIBLIA SAGRADA (Gênesis). Erechim: Edelbra, s/d.

BONFIN, Paulo Roberto de A. Território e Movimento Integralista: Uma Contribuição ao Estudo das Ideologias Geográficas no Pensamento Autoritário Brasileiro das Décadas de 1920-1930. Dissertação (Mestrado) Faculdade de Filosofia, Letras e Ciências Humanas - USP. São Paulo, 2001.

BORDALLO, Martha Martins. Representação Social e Análise do Discurso: Estudo em Entrevistas com Funcionários da Fundação Instituto Brasileiro de Geografia e Estatística - IBGE. Dissertação (Mestrado) Faculdade de Educação - UERJ. Rio de Janeiro, 1996.

CAMARGO, José Carlos Godoy. Evolução e Tendências do Pensamento Geográfico no Brasil: a Biogeografia. Tese (Livre Docência). Instituto de Geociências e Ciências Exatas - UNESP. Rio Claro, 1998.

CAMPOS, Rui Ribeiro de. A Dimensão Populacional na Obra de Josué de Castro. Tese de Doutoramento (Programa de Pós-Graduação em Geografia). de Geociências e Ciências Exatas - UNESP. Rio Claro, 2004.

CARVALHO, Antônio Alfredo Teles de. Josué de Castro na Perspectiva da Geografia Brasileira - 1934/1956: Uma Contribuição a Historiografia do Pensamento Geográfico Nacional. Dissertação (Mestrado). Centro de filosofia e Ciências Humanas - UFPE. Recife, 2001.

CARVALHO, Marcos Bernardino de. Uma Geografia de Discurso Sobre a Natureza. Dissertação (Mestrado) Faculdade de Filosofia, Letras e Ciências Humanas - USP. São Paulo, 1991.

CARVALHO, Maria Conceição Vicente de. Santos e a Geografia do Litoral Paulista. Tese (Doutoramento em Geografia) Faculdade de Filosofia, Ciências e Letras - USP. São Paulo, 1944.

CASTRO, Anna Maria de. Fome, um Tema Proibido: os últimos escritos de Josué de Castro. 2 ed. Petrópolis: Vozes, 1984. (3 ed. Recife: CEPE, 1996). 
CASTRO, Josué de. Geopolítica da Fome (ensaio sobre os problemas de alimentação e de população). 8. ed. (rev/aum.). São Paulo: Brasiliense, 1968. 2 v.

. Geografia da Fome - o dilema brasileiro: pão ou aço. 10 ed. São Paulo: Brasiliense, 1967.

- Crise Social e Desequilíbrio Econômico do Mundo. (texto originalmente elaborado a pedido da UNESCO para a publicação "Way Fórum" em 1956). 7 p.

A Coexistência Política e a Paz. (Discurso Pronunciado na cerimônia de entrega do Prêmio Internacional da Paz). Helsinque, 1954. 5 p.

Aos Pobres Pertence o Reino da Terra. (Discurso Pronunciado no Conselho Mundial da Paz ao presidir a sessão dedicada ao estudo das armas atômicas). Estocolmo, 1954. 7 p.

. O Espírito Geográfico da Filosofia Moderna. In: Boletim Geográfico. IX (101) Rio de Janeiro: IBGE, 1951. p. 545-547.

. A Função Social das Universidades. Rio de Janeiro: Sauer, 1948.

. Fatores de Localização da Cidade do Recife - um ensaio de geografia humana. Rio de Janeiro: Imprensa Nacional, 1948. (Reeditado em 1954 como "A Cidade do Recife: ensaio de geografia urbana", pela Casa do Estudante do Brasil. Rio de Janeiro)

Geografia Humana: estudo da paisagem cultural do mundo. Porto Alegre: Livraria do Globo, 1939.

A Alimentação Brasileira à Luz da Geografia Humana. Porto Alegre: Livraria do Globo, 1937. do Brasil, s/d. 5 p.

CONCEICÃO, Alexandrina Luz. Às Margens do Beberibe e do Capibaribe: a crítica de Tobias Barreto nos meandros da geografia. Tese de Doutoramento (Programa de Pós-Graduação em Geografia) Faculdade de Filosofia, Letras e Ciências Humanas - USP. São Paulo, 2001.

DIAS, Leila Christina. La Pensée Géographique Brésil: Hier et Aujourd'Hui. In: L’Espace Géographie. n. 3. Paris, 1989. p. 193-203.

DINIZ FILHO, Luís Lopes. Território Nacional: Ideologias Geográficas e Políticas Territoriais no Estado Novo (1937 - 1945). Dissertação (Mestrado) Faculdade de Filosofia, Letras e Ciências Humanas - USP. São Paulo, 1994. 
DOMINGOS, Patrícia M. Resgate da Vida e Obra de Josué de Castro. Monografia (Graduação). Escola de Saúde Pública - USP. São Paulo, 1997.

Encontro Nacional de História do Pensamento Geográfico, 1. Eixos Temáticos - Vol. I (Trabalhos Completos). Rio Claro: UNESP - IGCE, 1999. p. 38-42. Anais...

ETGES, Virgínia Elisabeta. Geografia Agrária: a contribuição de Leo Waibel. Tese de Doutoramento (Programa de Pós-Graduação em Geografia) Faculdade de Filosofia, Letras e Ciências Humanas - USP. São Paulo, 1997.

FAUSTO, Boris. História Concisa do Brasil. 2 ed. São Paulo: Edusp, 2006.

FERRAZ, Cláudio Benito O. O Discurso Geográfico: a Obra de Delgado de Carvalho no Contexto da Geografia Brasileira - 1913 a 1942. Dissertação (Mestrado) Faculdade de Filosofia, Letras e Ciências Humanas - USP. São Paulo, 1989.

FRANÇA, Ary. Estudo Sobre Clima na Bacia de São Paulo. Tese (Doutoramento em Geografia) Faculdade de Filosofia, Ciências e Letras - USP. São Paulo, 1945.

FREITAS, Inês Aguiar de. Em Nome do Pai. A Geografia dos Jesuítas no Brasil nos Séculos XVI a XVIII. Tese de Doutoramento (Programa de Pós-Graduação em Geografia). Centro de Ciências Matemáticas e da Natureza - UFRJ. Rio de Janeiro, 1992.

FREITAS, Inês Aguiar de. Em Nome do Pai. A Geografia dos Jesuítas no Brasil nos Séculos XVI a XVIII. Tese de Doutoramento (Programa de Pós-Graduação em Geografia). Centro de Ciências Matemáticas e da Natureza - UFRJ. Rio de Janeiro, 1992.

GEIGER, Pedro P. Industrialização no Brasil, Conhecimento e Atuação da Geografia. In: Revista Brasileira de Geografia. Rio de Janeiro, 1988. v. 50, n. especial, tomo 2, p. 59-84.

GOMES, Ângela de Castro. Autoritarismo e Corporativismo no Brasil: o Legado de Vargas. In: Revista USP, n 65, março/maio2005. São Paulo: Edusp, 2005.p. 105-119.

GOMES, Paulo César da C. Culturas Teóricas, Culturas Políticas no Espaço Geográfico. In: CASTRO, Iná Elias. de et al (Orgs.) Redescobrindo o Brasil : 500 anos depois. Rio de Janeiro: Bertrand Brasil, 1999. p. 335-339.

GUIDI, Eduardo Zons. Considerações sobre a Gênese da Geografia Humana Moderna: Friederic Ratzel e Paul Vidal de La Blache. Dissertação (Mestrado) Centro de Filosofia e Ciências Humanas - UFSC. Florianópolis, 1995. 
HOLZER, Werther. Um Estudo Fenomenológico Da Paisagem Do Lugar: A Crônica Dos Viajantes No Brasil Do Século XVI. Tese de Doutoramento (Programa de Pós-Graduação em Geografia) Faculdade de Filosofia, Letras e Ciências Humanas - USP. São Paulo,1998.

A Geografia Humanista: Sua Trajetória de 1950 a 1990. Dissertação (Mestrado). Centro de Ciências Matemáticas e da Natureza - UFRJ. Rio de Janeiro, 1992.

IANNI, Octávio. A Idéia de Brasil Moderno. São Paulo: Brasiliense, 1996.

Brasileira, 1994.

O Colapso do Populismo no Brasil. 5 ed. São Paulo: Civilização

LA BLACHE, Paul Vidal de. Princípios de Geografia Humana. 2 ed. rev. Lisboa: Cosmos, 1954.

LAMEGO, Mariana Araújo. Positivismo Lógico e a Geografia: Uma Interpretação entre o Circulo de Viena e a Geografia Quantitativa. Dissertação (Mestrado) - Instituto de Geociências - UERJ. Rio de Janeiro, 2006.

MACHADO, Mônica Sampaio. A geografia Universitária Carioca e o Campo Científico - Disciplinar da Geografia Brasileira. Tese de Doutoramento (Programa de Pós-Graduação em Geografia) Faculdade de Filosofia, Letras e Ciências Humanas - USP. São Paulo, 2002.

MAGALHÃES, Rosana. Fome: uma (Re)leitura de Josué de Castro. Rio de Janeiro: Fiocruz, 1996.

. MAGALHÃES, Rosana. A Fome no Pensamento de Josué de Castro. Dissertação (Mestrado). Escola Nacional de Saúde Pública - FIOCRUZ. Rio de Janeiro, 1992.

MAMIGONIAN, Armen. Estudos de Geografia Econômica e de História do Pensamento Geográfico. Tese (Livre Docência). Faculdade de Filosofia, Letras e Ciências Humanas - USP. São Paulo, 2005.

A Escola Francesa de Geografia e o Papel de André Cholley. In: Cadernos Geográficos. n. 6. Florianópolis: Imprensa Universitária, 2003. 44 p.

A AGB e a Produção Geográfica Brasileira: avanços e recuos. In: Terra Livre. n. 8. Porto Alegre: Marco Zera/AGB, 1991. p. 157-162.

MARCHI, Dorival D. O Pensamento Geográfico de Josué de Castro das Décadas de 40 e 50: a fome e a produção de alimentos. Monografia (Graduação). Instituto de Geociências e Ciências Exatas - UNESP. Rio Claro, 1998.

MARTINS, Luciana de Lima. Paisagens Brasileiras, Olhos Britânicos - O Rio de Janeiro dos Viajantes, 1800/1850. Tese de Doutoramento (Programa de 
Pós-Graduação em Geografia). Centro de Ciências Matemáticas e da Natureza - UFRJ. Rio de Janeiro, 1998.

- Friedrich Ratzel: através de um prisma. Dissertação (Mestrado). Centro de Ciências Matemáticas e da Natureza - UFRJ. Rio de Janeiro, 1993.

MARCHI, Dorival Donizeti. O Pensamento de Josué de Castro. Dissertação (Mestrado). Universidade São Francisco. São Paulo, 2004.

O Pensamento Geográfico de Josué de Castro das Décadas de 40 e 50: a fome e a produção de alimentos. Monografia (Graduação). Instituto de Geociências e Ciências Exatas - UNESP. Rio Claro, 1998.

MEGALE, Januário Francisco. Geografia e Sociologia: introdução ao estudo de Max Sorre. Tese de Doutoramento (Programa de Pós-Graduação em Geografia) Faculdade de Filosofia, Letras e Ciências Humanas - USP. São Paulo, 1980.

MELO, Adriany A. Trajetórias do Ensino de Geografia no Brasil - 19781996. Dissertação (Mestrado). Universidade Federal de Uberlândia. Uberlândia, 2001.

MENDES, Renato Silveira. Paisagens Culturais da Baixada Santista. Tese (Doutoramento em Geografia) Faculdade de Filosofia, Ciências e Letras - USP. São Paulo, 1948.

MENDONZA, Josefina Gómez. Geografías del Presente y del Pasado. Un Itinerario a través de la Evolución Reciente del Pensamiento en Geografía Humana (1970-1885). In: BALLESTEROS, Aurora Garcia. Teoría y Práctica de la Geografía. Madrid: Alhambra, 1986. p 3-43

MIGUEL, Nadya Maria Deps. IBGE: construção e preservação de memórias. Mem. Soc. Dissertação (Mestrado). Universidade Federal do Estado do Rio de Janeiro. Rio de Janeiro, 2006.

MONTEIRO, Carlos Augusto de F. A Geografia no Brasil ao Longo do Século XX: Um Panorama. In: O Borrador, n. 04, da AGB - São Paulo. São Paulo, 2002.

. Geografia 2001. In: MENEZES, Ana Virgínia Costa de et al (Orgs.). Geografia 2001. Aracaju: NPGEO/UFS, 2000. p. 153-163.

.A Geografia no Brasil (1934-1977): avaliação e tendências. São Paulo: Instituto de Geografia da USP, 1980.

MOTA, Carlos Guilherme. Ideologia da Cultura Brasileira (1933 - 1974) pontos de partida para uma revisão histórica. 9 ed. São Paulo: Ática, 1994.

MORAES, Antonio Carlos R. Bases da Formação Territorial do Brasil - 0 Território Colonial Brasileiro no “Longo" Século XVI. Tese de 
Doutoramento (Programa de Pós-Graduação em Geografia) Faculdade de Filosofia, Letras e Ciências Humanas - USP. São Paulo, 1991a.

. Ideologias Geográficas - Espaço, Cultura e Política no Brasil. 2 ed. São Paulo: Hucitec, 1991b.

. Contribuição para uma História Crítica do Pensamento Geográfico: Alexander von Humboldt, Karl Ritter, Friedrich Ratzel. Dissertação (Mestrado) Faculdade de Filosofia, Letras e Ciências Humanas - USP. São Paulo, 1983.

MULLER, Nice Lecoc. Sítios e Sitiantes. Tese (Doutoramento em Geografia) Faculdade de Filosofia, Ciências e Letras - USP. São Paulo, 1946.

NASCIMENTO, Renato Cavalheira do. Josué de Castro - O Sociólogo da Fome. Dissertação (Mestrado). Universidade de Brasília. Brasília, 2002.

. Josué de Castro: O Teórico do Mangue. Monografia (Graduação) Universidade de Brasília. Brasília, 1999.

NUNES, Jorge Luís R. Josué de Castro, o Geógrafo da Fome: Uma Abordagem Crítica da Obra e sua Relação com o Contexto Econômico e Político do Brasil. Dissertação (Mestrado). Universidade Federal do Rio Grande do Sul. Porto Alegre, 2003.

A Geografia Econômica na Produção Científica Acadêmica dos Programas de Pós-Graduação em Geografia no Estado de São Paulo (1970 - 1998). Dissertação (Mestrado). Faculdade de Ciência e Tecnologia UNESP. Presidente Prudente, 2000.

NUNES, Flaviana Gasparotti. O Econômico na Geografia - as Influências do Pensamento Econômico na Produção Geográfica (1970-2001) Tese de Doutoramento (Programa de Pós-Graduação em Geografia). Faculdade de Ciência e Tecnologia - UNESP. Presidente Prudente, 2004.

OLIVA, Terezinha A. de. O Pensamento Geográfico em Manoel Bonfim. Tese de Doutoramento (Programa de Pós-Graduação em Geografia) Instituto de Geociências e Ciências Exatas - UNESP. Rio Claro, 1999.

PENHA, Eli Alves. A Criação do IBGE no Contexto de Centralização Política do Estado Novo. Dissertação (Mestrado). (Programa de PósGraduação em Geografia). Centro de Ciências Matemáticas e da Natureza UFRJ. Rio de Janeiro, 1992.

PEREIRA, Diamantino Alves C. Origens e Consolidações da Tradição Didática na Geografia Escolar Brasileira. Dissertação (Graduação). Faculdade de Filosofia, Letras e Ciências Humanas - USP. São Paulo Universidade de São Paulo - USP. São Paulo, 1990. 
PEREIRA, José Veríssimo da Costa. A Geografia no Brasil. In: AZEVEDO, Fernando de (Org.). As Ciências no Brasil. V. I. 2 ed. Rio de Janeiro: Ed. UFRJ, 1994. p. 349-461.

PEREIRA, Sérgio Luiz Nunes. Sociedade de Geografia do Rio de Janeiro: Origens, Obsessões e Conflitos (1883-1944) Tese de Doutoramento (Programa de Pós-Graduação em Geografia) Faculdade de Filosofia, Letras e Ciências Humanas - USP. São Paulo, 2003.

Geografias - Caminhos e Lugares de Produção do Saber Geográfico no Brasil 1838 - 1922. Dissertação (Mestrado) Faculdade de Filosofia, Letras e Ciências Humanas - USP. São Paulo, 1997.

RAIMUNDO, Silvia Lopes. A Invenção do Mito Bandeirante. Tradição e Pensamento Regionalista na Historiografia Paulista das Décadas de 19201930. Dissertação (Mestrado) Faculdade de Filosofia, Letras e Ciências Humanas - USP. São Paulo, 2002.

REZENDE, Maria José de. As Desigualdades no Brasil: uma Forma de Violência Insuperável? As Reflexões de Manoel Bomfim, Euclides da Cunha, Fernando de Azevedo e Josué de Castro. In: SCHILLING, Flavia (Org.). Direitos Humanos e Educação - outras palavras, outras praticas. São Paulo: Cortez, 2005. p. 25-57.

RIBEIRO JÚNIOR, Dante Flávio da Costa. O Humano pelo Viés Quantitativo: Um Exame do (Neo) Positivismo em Speridiao Faissol. Dissertação (Mestrado). Instituto de Geociências e Ciências Exatas - UNESP. Rio Claro, 2003.

RIBEIRO JÚNIOR, José Raimundo S. O Movimento da Obra de Josué de Castro: Uma Releitura Crítica a Partir da Geografia e da Fome. Monografia (Graduação). Faculdade de Filosofia, Letras e Ciências Humanas - USP. São Paulo, 2004.

RUDZIT, Gunther. O processo de Formação do Oficial do Exército Brasileiro \& A Geografia (1850 - 1930) Dissertação (Mestrado). Faculdade de Filosofia, Letras e Ciências Humanas - USP. São Paulo, 1997.

SANTIAGO, João Phelipe. A Questão Nacional na Geografia Ratzeliana e sua Assimilação no Pensamento Social Brasileiro na República Velha. Tese de Doutoramento (Programa de Pós-Graduação em Geografia). Faculdade de Filosofia, Letras e Ciências Humanas - USP. São Paulo, 2005.

A Geografia no Brasil: a contribuição de Manuel Correia de Andrade. Dissertação (Mestrado). Centro de Filosofia e Ciências Humanas - UFPE. Recife, 1990.

SANTOS, Wilson dos. A Obra de Aroldo de Azevedo: uma avaliação. Dissertação (Mestrado) Instituto de Geociências e Ciências Exatas - UNESP. Rio Claro, 1984. 
SCARIM, Paulo César. Coetâneos da Crítica. Uma Contribuição ao Estudo do Movimento de Renovação da Geografia Brasileira. Dissertação (Mestrado). Faculdade de Filosofia, Letras e Ciências Humanas - USP. São Paulo, 2001.

SILVEIRA, João Dias da Silveira. Estudo Geográfico dos Contrafortes Ocidentais da Mantiqueira. Tese (Doutoramento em Geografia) Faculdade de Filosofia, Ciências e Letras - USP. São Paulo, 1946.

SILVEIRA, José Carlos da. Da Faculdade Catarinense de Filosofia à Gênese do Ensino Superior de Geografia. Dissertação (Mestrado). Centro de Ciências da Educação - UFSC. Florianópolis, 2004.

SILVA, Aldo Aloísio Dantas da. Conexidade, Complexo Geográfico de La Blache e de Pierre Monbeig. Tese de Doutoramento (Programa de PósGraduação em Geografia). Faculdade de Filosofia, Letras e Ciências Humanas - USP. São Paulo, 2002.

SILVA, Jorge Luiz Barcellos da. Notas Introdutórias de um Itinerário Interpretativo sobre a Formação do Pensamento Geográfico Brasileiro. Dissertação (Mestrado). Faculdade de Filosofia, Letras e Ciências Humanas USP. São Paulo, 1996.

SILVA, Tânia Elias M. da. Josué de Castro: Por uma Poética da Fome. Tese de Doutoramento (Programa de Pós-Graduação em Ciências Sociais). PUCSP. São Paulo, 1998.

SOUSA NETO, Planos para o Império: Os Planos de Viação do Segundo Reinado (1869-1889) Tese de Doutoramento (Programa de Pós-Graduação em Geografia) Faculdade de Filosofia, Letras e Ciências Humanas - USP. São Paulo, 2004.

Senador Pompeu: um geógrafo do poder no império do Brasil. Dissertação (Mestrado). Faculdade de Filosofia, Letras e Ciências Humanas USP. São Paulo, 1997.

SODRÉ, Nelson Werneck. Síntese da História da Cultura no Brasil. 4 ed. São Paulo: Civilização Brasileira, 1976.

TUAN, Y-Fu. Paisagens do Medo. São Paulo: Ed. da Unesp, 2005.

SORRE, Max. El Hombre em la Tierra. Barcelona: Editorial Labor, 1967.

. A Fome sem o Véu Discreto da Fantasia. In: O Drama Universal da Fome. Rio de Janeiro: Ascofam, 1958. p. 243-247.

SOUZA, Marcos Barros de. Geografia Física, Balanço da sua Produção em Eventos Científicos no Brasil. Dissertação (Mestrado) Faculdade de Filosofia, Letras e Ciências Humanas - USP. São Paulo, 2006. 
SOUZA, Renata Neder F. de. A Geografia Regional na Revista Brasileira de Geografia. Dissertação (Mestrado). Centro de Ciências Matemáticas e da Natureza - UFRJ. Rio de Janeiro, 2003.

SPOSITO, Eliseu Sevério. Contribuição a Metodologia de Ensino do Pensamento Geográfico. Tese (Livre Docência). Faculdade de Ciências e Tecnologia - UNESP. Presidente Prudente, 2000.

TAVARES, Luís Carlos. A Inserção da Obra de Josué de Castro no Pensamento Geográfico. Monografia (Graduação). Universidade de Brasília. Brasília, 1997.

THIESEN, Icléia. Memória Institucional do IBGE: um estudo exploratóriometodológico. Dissertação (Mestrado em Ciência da Informação). UFRJ. Rio de Janeiro, 1992.

TOZI, Fábio. Geografias da Desigualdade - Território e Fome. Monografia (Graduação). Universidade de Campinas. Campinas, 2001.

ZUSMAN, Perla Brígida. Sociedades Geográficas na Promoção do Saber ao Respeito do Território: estratégias políticas e acadêmicas das instituições geográficas na Argentina (1879-1942) e no Brasil (1838-1845). Dissertação (Mestrado) Programa de Pós-Graduação em Integração da América Latina USP. São Paulo, 1996. 
ANEXOS 


\section{Geografia da Fome}

\section{Nelson Werneck Sodré}

O assunto fome é bastante vasto e complexo. Seus aspectos são vários, embora os fundamentos e origens do fenômeno conduzam a uma conclusão lógica, a fome é um problema social. O turismo deixa de merecer reparos onde quer que se disfarce os problemas mudando-lhes o nome, ou vendo-os de algum ângulo técnico para disfarce de seus motivos essenciais. Embora o tema seja universal, porque a fome atravessou os tempos e não tem coordenadas precisas no espaço, é triste verdade que pôde ser bem estudado em nosso país onde apresenta alguns dos seus mais alastrados aspectos. E nem são aspectos novos, porque as crises de fome estão marcadas, na historia brasileira, historiógrafos meramente descritivos, como Southey, mencionaram algumas de suas manifestações mais antigas. A fome na região mineradora, por exemplo, de periodicidade incerta, e que devastou grupos numerosos, fundamentada na preocupação exclusiva do euro, fazendo esquecer as providencias indispensáveis à manutenção das massas humanas, deslocadas em curto espaço de tempo, para os altiplanos das Minas Gerais. Fenômeno que se repetiu em outras zonas da mineração, Mato Grosso por exemplo, a ponto de acarretar a medida vital das plantações periódicas do Camaquam destinadas a subsistência do pessoal das monções, que demandava as antigas lavras do Sutil, nas margens do Cuiabá.

Sobre o assunto, sobre um dos seus mais curiosos aspectos geográficos, acaba de publicar o sr. Josué de Castro uma obra cheia de interesse: Josué de Castro "Geografia da Fome”, Edições Cruzeiro, Rio, 1946, 354 páginas. Tratase de um amplo estudo, que comportará novos volumes. Neste, estuda o autor, em particular, a fome no Brasil. Trata-se de um trabalho feito com segurança, baseado em demoradas pesquisas e cujas conclusões, se disentíveis por vezes, merecem sempre atenção. Especialista em nutrição, o autor não é um desses estudiosos que se deixa obcecar, por uma face do problema, sacrificando-lhe a sua riqueza de coteúdo e as contribuições que os demais ângulos podem oferecer. 
Num longo prefácio, que situa o problema, e encerra algumas contribuições interessantes, explica o autor como o tema vem se conservando como um tabu, em toda parte, de tal sorte que a bibliografia a seu respeito permanece exígua, em discordância com sua indiscutível importância, e como só em nosso tempo vem merecendo estudos especiais, em particular estudos regionais, destinados à alteração de dietas propiciadoras de males ou mais alastrados. A explicação de que o silêncio em torno do fenômeno parece premeditado pela própria alma a cultura, fomentado pelos interesses de ordem moral e de ordem material, é aceitável, conforme acentua o sr. Josué de Castro.

Embora a fome seja um tema eterno, de que tratam os mais velhos livros humanos, é bem frisante que algumas de suas crises mais intensas e largas tenham ocorrido na fase de expansão comercial, na época moderna da historia, aquela que os compêndios assinalam entre a queda de Constantinopla e o irrompimento da primeira guerra mundial. É verdade que os textos medievais se referem à fome, e a época de intensa mobilidade geográfica que foi a das cruzadas proporcionou, em fase de economia fechada e dispersa do regime de propriedade existente, mortalidades que marcaram instantes assinaláveis da vida coletiva. Só a idade do individualismo, desenvolvimento da economia burguesa, da apropriação das fontes de matérias primas, do domínio das rotas de distribuição, entretanto, conseguiu fazer esquecer esses surtos espaçados de fome, levando o aparecimento do fenômeno a regiões cuja riqueza era notória e que jamais poderiam ser palco de contraste tão grave. É o caso da Índia, mencionado pelo sr. Josué de Castro, repetindo a observação de Richard Vemple, que exportava quantidades consideráveis de cereais e pedia milhões de habitantes vítimas da fome, pondo a nú as tremendas mazelas do sistema de distribuição da riqueza.

Critica o autor, com razão, os estudos científicos sobre o assunto, limitados a aspectos parciais do mesmo, quase sempre aspectos técnicos, com que se procura esconder a sua verdadeira dimensão e seu exato sentido, particularmente o trabalho de fisiologos, de químicos e outros especialistas. Para quebrar essa visão unilateral de problema de tamanha gravidade, 
apresentado-o num quadro de conjunto, escolheu o sr. Jusué de Castro o método geográfico como compatível com a necessidade, não o método descritivo, lembra bem, mas o método interpretativo fundamentado na ecologia. Para tanto, recorda as palavras de Vital de La Blache: "entre as forças que ligam o homem a determinado meio uma das mais tenazes é a que transparece quando se realiza um estudo dos recursos alimentares regionais". Dentro do critério geográfico, pois, busca o autor "analisar os hábitos alimentares dos diferentes grupos humanos, ligados a determinadas áreas geográficas, procurando de um lado, descobrir as causas naturais e as causas sociais que condicionaram o seu tipo de alimentação, com suas falhas e defeitos característicos, e, de outro lado, procurando verificar até onde esses defeitos influenciam a estrutura econômico-social dos diferentes grupos estudados". Conclui o autor essa parte da explicação do sentido de sua obra, considerando: "Assim fazendo, acreditamos poder fazer alguma luz explicativa a inúmeros fenômenos de natureza social até hoje mal compreendidos por não terem sido levados na devida conta os seus fundamentos biológicos".

De nossa parte, acreditamos que o processo da fome é fundamentalmente social, e só tratável através de medidas social, no seu quadro geral. Nos aspectos particulares é que ele pode ser tratado em seus fundamentos biológicos. Quando o autor afirma que o seu interesse está em "analisar o fenômeno da fome coletiva - da fome atingindo endêmica ou epidemicamente as grandes massas humanas", é claro que se refere ao quadro geral. É evidente que a fome é um processo biológico, sem afetar aquele desequilíbrio, é como anunciar "beba mais leite" onde não há leite e a quem não pode comprar leite... Cremos, entretanto, que não há propriamente discordância entre os dois pontos de vista, apenas um jogo de palavras.

Explicando como resolveu dedicar o primeiro volume de sua obra ao nosso país, frisa bem o autor que "nenhum país do mundo se prestaria, tanto quanto o nosso, para funcionar como um verdadeiro laboratório de pesquisa social deste problema", com o que todos devem estar de acordo. No caso, aliás, vale o sr. Josué de Castro a sua larga experiência, em diferentes regiões brasileiras, os estudos particulares já levados a efeito, a facilidade na colheita 
de dados, a indiscutida autoridade que já possui para o trato assunto. Conhece bem o autor o quadro apresentado pelo nosso país, na especialidade, bem destacado naquele panorama das condições de vida da América Latina, apresentado por George Soule, David Efron e Norman T. Nes, no livro, "Latin América in the future World", que cita em destaque, e por onde se comprova, com tristeza, que dois terços das populações desta parte do mundo constituem-se de sub-nutridos, três quartos de analfabetos, metades de doentes de infecção ou carência, dois terços não recebem assistência social, um terço não participa da vida econômica, dois terços vivem em condições semi-feudais de trabalho, a esmagadora maioria não possui terras.

Divide o autor o Brasil em cinco áreas alimentares, cada uma dispondo de recursos característicos, e a com uma deita habitual: a da Amazônia, a da mata do Nordeste, a do sertão do Nordeste, a do centro-oeste e a do extremo sul, nem todas áreas de fome, a rigor. Somente as três primeiras podendo ser enquadradas na denominação. Estas, merecem então, do autor, um acurado estudo.

Caracterizada a área amazônica, no seu quadro geográfico, explica o autor como o alimento básico permanece ali a farinha de mandioca, assinalando as suas deficiências. Passa, em seguida, ao estudo da área do nordeste açucareiro, estabelecendo o quadro histórico do estabelecimento da monocultura, e suas conseqüências. Estabelece a contribuição de índios, na alimentação dos grupos humanos, do nordeste canavieiro e aprecia as deficiências da dieta ali imperante. Transita para o estudo da área do sertão do Nordeste, delimitando-a e frisando o papel do clima na sua caracterização. Aprecia a flora e a fauna e estuda o alimento básico da região, o milho.

As duas áreas restantes, não configuradas a rigor como de fome, são apreciadas em conjunto, rapidamente, tirando o autor as conclusões gerais do problema brasileiro, encerradas em quinze interessantes itens. Dessa forma, o sr. Josué de Castro nos dá uma visão da fome no Brasil, através de pesquisas, depoimentos e analise de fatores, estabelecimento de contrastes e apreciações históricas e de todos os aspectos culturais e biológicos do problema. A obra se 
apresenta cheia de dados interessantes, escrita com um interesse quase fremente, plena de atração e digna de atenta leitura. Muito há que aprender, em suas paginas, escritas por um especialista, que não se estratifica em sua especialidade, que sabe situa-la no conjunto dos fatores que motivam e alteram a existência coletiva, alguém que, conhecendo o problema, e sabendo dissocia-lo expô-lo, oferece-o com a sua gravidade premente, neste instante de dúvidas e de apreensões.

Fonte: Correio Paulistano. São Paulo, 22 de janeiro de 1947.

OBS. Transcrito conforme o original 


\title{
A FUNÇÃO SOCIAL DAS UNIVERSIDADES
}

\author{
Oração do Professor Josué de Castro ao Tomar Posse \\ da Cátedra de Geografia Humana da Faculdade Nacional de Filosofia
}

O PENSADOR BRASILEIRO Tristão de Athayde, procurando dar maior brilho à Semana da Universidade Católica, escreveu um sereno e bem meditado ensaio acêrca do verdadeiro humanismo universitário. Acêrca das qualidades essenciais que devem caracterizar o espírito de uma universidade autêntica.

Defendendo com muita razão a tese de que é necessária antes de mais nada a re-humanização do ensino universitário hoje tão desumanizado pela técnica e pelo fanatismo pragmatista, o sr. Tristão de Athayde aproxima conceitos de universidade de dois séculos diferentes, mas que a seu ver traduzem uma mesma aspiração, uma mesma idéia de universidade: o conceito do cardeal Newman em meados do século passado e o conceito de Leavis em meados do nosso século. Para o ilustre crítico brasileiro, só haverá Universidade e verdadeiro espírito universitário, quando suas atividades intelectuais estiverem banhadas por uma onda de humanismo embebida das admiráveis qualidades preconizadas por Newman: a liberdade, o equilíbrio, a calma, a moderação, a sabedoria. Nos tempos que correm, eu gostaria muito que o sr. Tristão de Athayde tivesse acrescentado à substância universitária mais uma qualidade, que me parece das mais indispensáveis para que se mantenha a dignidade do espírito universitário: a tolerância. Nenhuma falha é mais grave e poderá deturpar mais a fundo o sentido cultural de uma universidade do que a intolerância de qualquer categoria. Nada mais distante do clima cultural universitário do que o sentencioso e o dogmático e nada mais estimulante à sua vida do que a tolerância compreensiva.

Uma universidade católica só poderá aspirar à categoria de uma verdadeira universidade, abrindo amplamente as suas portas à investigação e ao livre debate tanto das idéias religiosas como das leigas, tanto das raízes sobrenaturais como das naturais dos problemas. Só êste destemor diante da 
verdade seja qual fôr a sua mensagem, uma universidade católica se afirmará como autêntica universidade, sem perder por isto os seus foros de catolicismo. E é isto mesmo, o que deseja o sr. Tristão de Athayde quando afirma que uma universidade dêsse tipo deve possuir o mesmo humanismo de uma universidade leiga. Pensando dêste modo, não creio que o escritor brasileiro tenho sido tenho sido muito feliz ao apoiar seu pensamento, na idéia de universidade, do cardeal Newman. Basta lembrar que o humanista Newman, em seu célebre ensaio "A idéia de uma Universidade" afirma que "descobrir" e ensinar são duas funções distintas" e o que compete à Universidade é ensinar. A pesquisa para Newman é função do que êle chama academias doutas e não da universidade. Não creio que o sr. Tristão de Athayde também pense desta forma e faça qualquer restrição à função de investigação das Universidades.

Mas não é apenas a intolerância religiosa que deve ser banida do ensino universitário, mas a intolerância a serviço de qualquer fanatismo, seja ideológico, seja mesmo rigorosamente científico. A verdade é que há também um fanatismo científico que se apresenta muitas vezes com agressiva ferocidade: o fanatismo do cientificismo estreito, detentor de verdades parciais e sempre temeroso de tôda aventura da inteligência que possa alterar a disposição clássica e a estrutura do quadro geral do mundo, vindo a mudar o feitio dos encaixes onde cabiam primitivamente os seus pedacinhos de verdade. Há vários exemplos desta intolerância científica partindo mesmo de grandes universidades e se constituindo como uma negação do espírito universitário e como uma barreira ao próprio progresso da ciência.

Quando em fins do século passado o notável investigador holandês Cristian Eijkman descobriu em Java que o beribéri era causado por falta de alguma cousa essencial na alimentação dos orientais e publicou suas originais observações nas revistas européis, recebeu os mais duros impropérios da ciência oficial de várias universidades onde se considerava o beribéri como uma doença infecciosa. Não adiantou ao então jovem médico militar afirmar que tinha reproduzido a doença em galinhas alimentando-as com uma dieta incompleta igual à usada pelos habitantes de Java. A ciência oficial dos tempos não acreditava em experiências com galinhas e acusva intolerantemente a 
Eijkman de ser um aventureiro e um charlatão. Não tinha êle partido do Oriente lendário em busca de aventura? ... Era certamente um simples aventureiro. $\mathrm{O}$ aventureiro Ejikman tinha razão e a ciência oficial negando a valia das suas afirmações deixou morrer criminosamente vários milhões de indivíduos de beribéri por simples ato de intolerância. Só quarenta anos depois esta ciência oficial se penitenciou reconhecendo integralmente o valor das teorias de Eijkman e concedendo-Ihe como uma tardia compensação o premio Nobel que êle já não pôde ir receber por que se encontrava às portas da morte. Seria fácil apresentar inúmeros outros exemplos, mas creio que êste basta como demonstração de uma forma pouco lembrada de intolerância - a intolerância da ciência.

Tenho contudo a impressão que as qualidades essenciais, indispensáveis à vida universitária não podem ser adquiridas através de recomendações teóricas, nem mesmo por sua insistente repetição. São qualidades que só podem nascer através da própria experiência universitária. Só se exercitando em suas elevadas funções a universidade ganha suas qualidades de pureza e de autenticidade e só possuindo estas qualidades pode ela desempenhar autênticamente as suas funções.

A Universidade deve ser o centro coordenador das mais altas atividades intelectuais. Nela se destila o saber como a essência intelectual da vida de uma cultura. Desta forma, deve a Universidade estar sempre indissoluvelmente ligada ao organismo social que a gera e ao qual ela deve servir plenamente. Suas funções básicas são as de criar conhecimentos, de propagá-los e difundilos e de defender as suas verdades contra as fôrças eventuais do obscurantismo. Três, pois, são as suas missões: a de investigação criadora; a de ensino universitário; a de vigilância e de defesa da cultura.

A investigação é a sua função primeira "cronológica e hierarquicamente" - afirma o grande cientista argentino Bernardo Houssay - desde que a Universidade deve criar conhecimentos para depois difundi-los. Não procedendo assim, a Universidade perde sua hierarquia e cai na categoria de uma simples escola de artes e ofícios, onde se repetem conhecimentos e 
técnicas bebidos em fontes alheias, de elaboração estranha. A Universidade formada pelo simples agrupamento de escolas técnicas profissionais, envolvidas com um pouco de tecido conjuntivo convencional também está longe do sentido autêntico de Universidade. Por outro lado, um simples instituto de tecnologia onde se pratique a investigação original, ganha foros de Universidade, independente do rótulo e da fachada. Infelizmente entre nós não se dava a devida importância aos trabalhos de investigação e ao de formação do espírito do investigador. E a verdade é que sem a pesquisa viva, sofre o ensino uma tremenda degradação. Faz-se uma aprendizagem quase sem a participação do pensamento, como um simples acúmulo, às vezes até prejudicial, de noções de preceitos preestabelecidos. A própria ciência, assim aprendida, torna-se suspeita - é uma pseudociência, instrumental e formulária, muitas vêzes perigosamente manejada, com inconsciência e insciência. Ademais, como o crescimento da ciência e da cultura é incessante e se nutre sempre pelas raízes da pesquisa original, a Universidade sem pesquisa é uma árvore morta, com o seu tronco aparentemente ficando num solo fértil, mas separado das raízes que deviam absorver os elementos formadores de sua seiva vital. E logo a árvore definha, murcha e seca, e, ao invés de dar frutos e sombra, permanece apenas como um obstáculo, como um espectro do passado morto. Foi longe de contribuírem para a evolução cultural, se constituíram mesmo em barreiras empedernidas ao progresso da humanidade.

O problema do ensino universitário não é tão simples como possa parecer à primeira vista, desde que êle se pode realizar através de variados caminhos e visar a diferentes fins. A antiga universidade medieval, e mesmo renascentista, promovia um tipo de ensino visando a formação de uma cultura geral. Cultura que era uma súmula do saber humano, nos variados aspectos em que o conhecimento abrangia a realidade vigente. Naqueles bons tempos, o saber era limitado e era possível metê-lo, inteirinho e sem grandes deformações, no acanhado recinto de um cérebro humano. Era a época dos humanistas, dos enciclopedistas. Da universidade - escola de sábios. A verdade é que êsse tipo de universidade, mais do que uma escola de criação de cultura era um armazém de fatos. $O$ seu saber era mais noticioso do que 
compreensivo, desde que era pequena a preocupação de então em alcançar a unidade de conhecimentos oculta na multiplicidade torrencial dos fatos. Alguns espíritos fortes, verdadeiras cabeças enciclopédicas, como um Aristóteles, um Leibnitz ou mesmo um Kant, atingiram, contudo, êsse supremo anelo da inteligência humana. Nos tempos modernos, os conhecimentos se ampliaram de maneira tão vertiginosa que o dilatado saber humano não mais pôde caber dentro de uma cabeça. Passou a época dos sábios enciclopedistas. Perdeu a erudição o seu prestígio universitário e a ciência tomou a dianteira do ensino superior. Na universidade do século XIX vamos encontrar o ensino não mais visando a transmitir uma imagem unitária do mundo, mas fornecer clichês de suas realidades parciais, cientificamente mutiladas. O tremendo impacto do progresso científico acabou por fragmentar a cultura, por pulverizá-la em pequenos grãos de saber. Cada especialista de ciência, agarrando-se com unhas e dentes ao seu grão de poeira, virando-o e revirando-o sob a potente lente do seu microscópio, para penetrar o seu microcosmo, com uma pasmosa indiferença e uma maciça ignorância por tudo mais que se passa em derredor. Nas universidades européias e norte-americanas, nos tempos modernos, desenvolveu-se, ao extremo êsse tipo de ensino visando a especialização e criando dentro da cultura um tipo de ensino visando a especialização e criando dentro da cultura um tipo sui generis de civilização a civilização dos especialistas - dirigida por homens de rigorosa visão técnica, mas com uma visão cultural de míopes. De deplorável miopia política. Com razão afirma Ortega y Gasset, que êste tipo de universidade é responsável pela formação dos "novos bárbaros" - homens cada vez mais sábios e cada vez mais incultos". E o que é mais grave é que êsse é o tipo dominante das nossas elites culturais, representando êsse processo de dinâmica social que os levou, ao que Rathenau chamou, com muita propriedade "a invasão vertical dos bárbaros". Os especialistas de tipo limitado, à norte-americana, "homens que sabem cada vez mais de cada vez menos", constituem um dos produtos altamente perigosos para a vida da cultura. Há mesmo quem afirme que êles contribuíram decisivamente para precipitar a decadência da cultura ocidental e vai nessa afirmação uma grave denúncia às universidades que formaram, 
porque não souberam cumprir uma das suas missões básicas, a de guardiã e defensora da própria cultura e da civilização.

Compete às universidades acompanhar de perto a marcha da cultura, com o mesmo cuidado que dedica um jardineiro ao cultivo de suas plantas. É que a evolução cultural se processa pelo germinar contínuo de elaborações e de convicções criadas pelo suceder das gerações.

No mundo ocidental moderno, esta capacidade de criar novos valores universais, de construir um sistema de convicções novas, ficou reduzida ao mínimo, deste que a massa dos homens como que perdeu o contacto com a essência total e integral da cultura. E a cultura desamparada, pela fôrça de criação individual, está fatalmente condenada à decadência e ao extermínio. Há ainda um fundamento de ordem biológica, capaz de explicar por tal mecanismo a evolução, a decadência e a morte das civilizações: é através da teoria biológica dos reflexos condicionados de Pavlov. Da aplicação dessa teoria ao mecanismo de formação dos valores culturais. Civilização não é mais do que a elaboração mental e o manejo cada vez mais complicado, no campo das aplicações diuturnas, das aquisições do período de contemplação, que constitui a primeira fase da evolução das culturas. Na sua segunda fase, não mais contemplativa e de meditação, mas de manejo e de ação o grupo humano condiciona complicados reflexos, à base dos excitantes iniciais que são os símbolos interpretativos de sua cultura. Em seu sucessivo condicionamento, vai assim a cultura evoluindo, até ser alcançando o seu limite, desde que há sempre uma limitação fisiológica para o condicionamento reflexo, como demonstrou Pavlov em suas sensacionais experiências em animais. Atingindo êsse limite de condicionamento, a civilização estaciona. Chega-se às fases de estagnação e de decadência, com as suas típicas crises culturais caracterizadas pela perda de significação dos seus símbolos interpretativos e de seu estilo de vida social e política. Pela falta de confiança generalizada nas idéias, pela descrença absoluta nas palavras que já nada dizem e já não podem trazer qualquer solução neste momento crepuscular em que se avizinha a morte definitiva de tôda a alma de uma cultura. Ora, chega-se tanto mais rapidamente a essa fase de saturação de condicionamentos, quanto maior o 
número de excitantes condicionadores e quanto mais se distancia o grupo humano das raízes de sua cultura, isto é, dos seus símbolos de criação original, que são os excitantes básicos de sua formação. Foi o que aconteceu ao homem da cultura ocidental, impulsionado por uma fôrça cultural de um ímpeto tão desvairado, que o desterrou dentro de sua própria cultura. Estas razões biológicas que levaram os europeus dêste comêço do século $X X$ a se deixarem arrastar pela enganadora magia de certos gestos dominadores. Gestos cuja eficácia não é constante, mas apenas circunstancial, como já o afirmara Gregório Marañon. Só em determinadas circunstâncias históricas, nos momentos desesperados de crise, adquire o gesto do domador, êste valor definitivo que transfigura a massa numa pasta maleável, submissa à sua mão de ferro. Foi o que aconteceu na Europa nas primeiras décadas no nosso século. Nessa hora européia, quando cada um se sentia incapaz de marchar para a frente com o enorme pêso da cultura sôbre os ombros, entregaram-se os povos, voluntariamente, à sugestão dos gestos dominadores. Sem saber o que fazer da sua vontade individual, sem ter nada que construir com suas próprias mãos, êsses pobres sêres angustiados cederam ao gesto imperativo. Escravizaram-se em pensamento e ação e repetiram, autômatos, o gesto comum que é a expressão da renúncia à personalidade. Da perda voluntária da liberdade individual, mas, também, o sossêgo momentâneo pela fuga à responsabilidade. Pela supressão da dor de pensar pensamentos estéreis que não os conduzia à solução alguma. Muito se assemelhou essa psicose coletiva com a dos pobres cães das experiências de Pavlov sôbre os reflexos condicionados. Pobres animais que, depois de condicionarem inúmeros e complicados reflexos sob a ação contínua de repetidas excitações, chegaram ao máximo de sua capacidade de aprender e entravam numa fase de angústia, quando o terror os inibia de qualquer reflexo de defesa. Chagavam, mesmo, a desaprender tôdas as suas aquisições e já não sabiam como se conduzir diante das excitações mais elementares.

O excesso de condicionamento a que o europeu foi submetido pelo impulso da cultura ocidental altamente especializada levou-o a um estado semelhante. Estado de ansiedade muito bem caracterizado por Pierre Janet, 
nas seguintes palavras: "Hoje, um número de deprimidos é enorme, de indivíduos que não possuem energia suficiente para se ocuparem da causa pública, porque têm pavor da ação, principalmente da ação social. Sentem uma necessidade enorme de orientação e de proteção, e daí a idéia da ditadura lhes seduzir sobremodo".

Nesse momento triunfaram os novos mágicos da política, ilusionistas da cultura, que tomando das idéias já gastas e dos valores culturais já vazios os envolveram em grandes gestos teatrais, e os apresentaram assim embrulhados aos olhos hipnotizados das massas sofredoras, como frutos frescos, fecundados por uma onda de renascimento intelectual do clima europeu. Assim desapareceram por um momento os problemas insolúveis, impossíveis e irremediáveis. Hoje êsses problemas voltam. Diante dos olhos cansados, surgem os mesmos obstáculos intransponíveis. $E$ os homens sentem surdamente que os gestos nada resolveram. Que está tudo como antes. É a crise em marcha...

Dêsse naufrágio da cultura ocidental é possível, contudo, salva-se alguma coisa. Os povos do continente americano, embora formados pelo impulso modelador da cultura européia, possuem hoje uma organização cultural um tanto de sangue como de traços culturais, conduziram a uma recombinação de fatôres determinantes, que deram origem a um novo impulso cultural. Impulso que está ainda em sua face de ascensão cíclica. Não se sente na América aquêle cheiro de morte que paira no ar europeu desde o comêço do século, mas um hálito quente de vida em germinação. Os povos da América desejam apenas ter o pensamento livre para criar e as mãos livres para construir, e poderão triunfar do momento difícil que atravessa o mundo. Cabe, porém, nesse trabalho de defesa de uma cultura ainda não amadurecida, contra os perigos dos contágios exóticos e contra as infestações de possíveis metástases do câncer nazi-fascista, extirpado do organismo mundial à custa de tremendos sofrimentos e irremediáveis mutilações, um papel preponderante às universidades. Cabe às universidades americanas o alto dever de zelar pelo patrimônio cultural do nôvo mundo e permitir que a curva evolutiva de sua cultura atinja o nível máximo de suas possibilidades. Neste sentido devemos 
orientar o nosso ensino universitário de modo a evitar o grave êrro de sua criminosa desumanização, a evitar o ensino desumanizante, feito, como acentua com muita propriedade D. Manuel Garcia Morente, à base de "conhecimentos fragmentários, truncados, torsos de teorias sem base de apoio e conceitos carentes de inteligibilidade"... enfim, através de uma conduta didática que absorveu tudo "humanismo" dentro do puro "cientificismo", desvirtuando desta forma a ordem hierárquica e a própria realidade natural.

O ensino de pura especialização científica é uma grave limitação à compreensão e à convivência cultural e a sua instituição atinge não só o futuro do estudante, mas o prejudica mesmo em seu passado, antes que êle atravesse as portas da Universidade. É que os candidatos a êste tipo de ensino universitário começam a se especializar na escola secundária, orientando-se para uma determinada Faculdade e procurando adquirir já nessa fase, o nível mental adequado às exigências do seu ingresso.

Ora, essa especialização tão precocemente estabelecida cria uma visão da cultura de deplorável estreiteza. A verdadeira universidade deve ter sempre ao lado, mais do que ao lado, consubstanciado mesmo com o ensino técnico científico, o ensino de cultura geral, das disciplinas ou sistemas humanísticos. Não basta um certo verniz de cultura, umas tintas de erudição como um arrebique ou luxo de pedanteria, mas é preciso incutir nos espíritos em formação todo um sistema de cultura, um método de interpretação, que oriente sua própria vida. O ensino universitário deve ser, pois, antes de tudo, um ensino do orientação vital, processado de acôrdo com as aspirações totais da vida humana, no qual a ciência e a técnica sejam valorizadas como instrumentos de um ideal de cultura a serviço da humanidade. Quando Taine dizia que sem Filosofia o sábio não passa de um obreiro e 0 artista de um diletante, referia-se à necessidade de que o indivíduo esteja sempre intuitivamente prêso ao consenso universal, através de quaisquer interpretações, para que as suas expressões tenham um significado de verdades ou de belezas. Êste consenso universal é o que se chama Cultura, a qual abrange, em seu organismo, tôdas as manifestações sensíveis e racionais do humano: a beleza artística, a verdade científica, o conceito filosófico, a 
estrutura política, a fé religiosa - tudo isso se exprimindo numa interpretação orgânica, dentro do princípio de solidariedade da partes para a manutenção do todo.

Realizando as pesquisas que renovarão incessantemente a experiência humana e transmitindo de maneira adequada o saber, as universidades terão realizado implicitamente uma grande parte da sua terceira missão: a de defensores da cultura. Resta-lhes apenas, para o seu pleno desempenho, que elas usem corajosamente o seu direito de opinar com liberdade e de criticar com veemência, sempre que estejam em perigo os fundamentos da cultura e os seus valores vitais.

São estas, a nosso ver, as principais funções de uma verdadeira universidade. Funções que, em tôda a sua múltipla grandeza podem ser reduzidas em essência a uma só: a de re-humanização do homem.

É neste ponto que o nosso pensamento coincide integralmente com o do humanismo universitário do ilustre pensador brasileiro Tristão de Athayde, e creio que com o de todos os homens de boa vontade que encaram com tolerância e honestidade o trepidante momento cultural que a humanidade atravessa. Para êstes, as universidades, mais do que oficiais de sábios devem ser fábricas de Homens. De homens capacitados a promover a fusão dos seus valores individuais mais significativos, com as aspirações mais profundas da sociedades de que participam. De homens aptos a resolver a crítica circunstância da convivência do homem com o próprio homem.

Fonte: Jornal do Comercio. Rio de Janeiro, 18 de julho de 1948

OBS. Transcrito conforme o original 
